\title{
CONTRIBUCIÓN A LA DOSIMETRÍA PERSONAL EN PRUEBAS MÉDICAS RADIOLÓGICAS PARA ENTORNOS REGIONALES
}

\section{ENRIQUE ÁNGEL GARCÍA ANGOSTO}

Departamento Tecnologías de la Información y las Comunicaciones

Universidad Politécnica de Cartagena

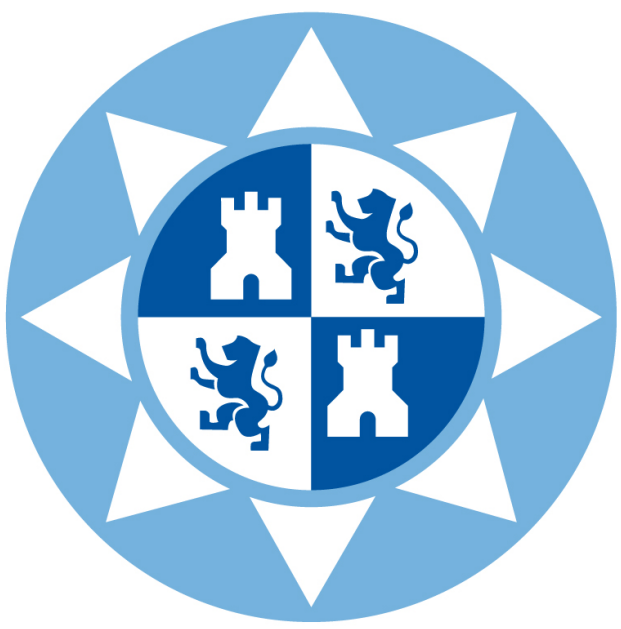

TESIS DOCTORAL POR COMPENDIO

Julio 2019

Director:

Dr. Antonio Javier García Sánchez

Codirector:

Dr. Alfredo Serna Berna 


\title{
Universidad
}

Politécnica

de Cartagena

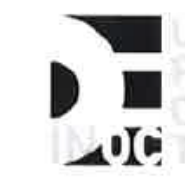

DT-16

\section{CONFORMIDAD DE SOLICITUD DEAUTORIZACIÓN DE DEPÓSITO DE}

\author{
TESIS DOCTORAL POR EL/LA DIRECTOR/A DE LA TESIS
}

D. Antonio Javier García Sánchez y D. Alfredo Serna Berna, Director y Codirector de la Tesis doctoral titulada CONTRIBUCIÓN A LA DOSIMETRÍA PERSONAL EN PRUEBAS MÉDICAS RADIOLÓGICAS PARA ENTORNOS REGIONALES.

\section{INFORMA:}

Que la referida Tesis Doctoral, ha sido realizada por D. Enrique Ángel García Angosto, dentro del Programa de Doctorado Tecnologías de la Información y las Comunicaciones, dando mi conformidad para que sea presentada ante el Comité de Dirección de la Escuela Internacional de Doctorado para ser autorizado su depósito.

$\otimes$ Informe positivo sobre el plan de investigación y documento de actividades del doctorando/a emitido por el Director/ Tutor (RAPI).

La rama de conocimiento en la que esta tesis ha sido desarrollada es:

[. Ciencias

C Ciencias Sociales y Jurídicas

$\otimes \quad$ Ingeniería y Arquitectura

En Cartagena, a 3 de Julio de 2019

EL/LA DIRECTOR/A DE LA TESIS

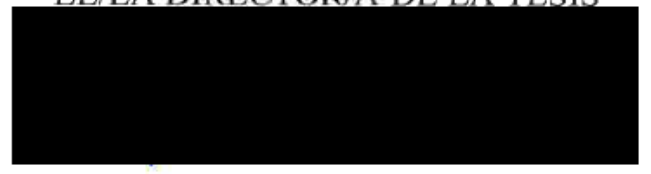

Fdo.: Antonio Javier García Sánchez

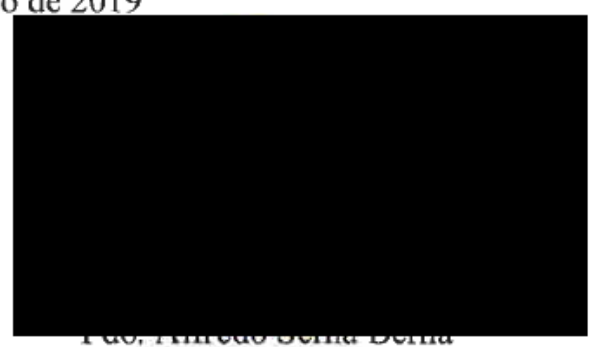

\section{COMITÉ DE DIRECCIÓN ESCUELA INTERNACIONAL DE DOCTORADO}




\section{CONFORMIDAD DE DEPÓSITO DE TESIS DOCTORAL} POR LA COMISIÓN ACADÉMICA DEL PROGRAMA

D. Jorge Larrey Ruiz, Presidente/a de la Comisión Académica del Programa Tecnologías de la Información y Comunicaciones.

\section{INFORMA:}

Que la Tesis Doctoral titulada, "CONTRIBUCIÓN A LA DOSIMETRÍA PERSONAL EN PRUEBAS MÉDICAS RADIOLÓGICAS PARA ENTORNOS REGIONALES", ha sido realizada, dentro del mencionado Programa de Doctorado, por D. Enrique Ángel García Angosto, bajo la dirección y supervisión del Dr. Antonio Javier García Sánchez y del Dr. Alfredo Serna Berna.

En reunión de la Comisión Académica, visto que en la misma se acreditan los indicios de calidad correspondientes y la autorización del Director/a de la misma, se acordó dar la conformidad, con la finalidad de que sea autorizado su depósito por el Comité de Dirección de la Escuela Internacional de Doctorado.

$\otimes$ Evaluación positiva del plan de investigación y documento de actividades por el Presidente de la Comisión Académica del programa (RAPI).

La Rama de conocimiento por la que esta tesis ha sido desarrollada es:

Ciencias

Ciencias Sociales y Jurídicas

$\otimes \quad$ Ingeniería y Arquitectura

En Cartagena, a 4 de Julio de 2019

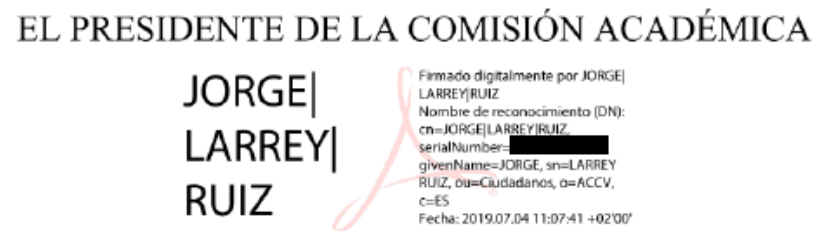

Fdo: Jorge Larrey Ruiz 
Visto el informe favorable del Director de Tesis y el $\mathrm{V}^{\mathrm{o}} \mathrm{B}^{\mathrm{o}}$ de la Comisión Académica del Programa de Doctorado "Tecnologías de la Información y las Comunicaciones" para la presentación de la Tesis Doctoral titulada: "Contribución a la dosimetría personal en pruebas médicas radiológicas para entornos regionales" solicitada por D. EnRiQue Ángel García Angosto, el Comité de Dirección de la Escuela Internacional de Doctorado de la Universidad Politécnica de Cartagena, en reunión celebrada el 25 de julio de 2019, considerando lo dispuesto en el artículo 23 del Reglamento de Estudios Oficiales de Doctorado de la UPCT, aprobado en Consejo de Gobierno el 17 de diciembre de 2015,

\section{ACUERDA}

Autorizar la presentación de la Tesis Doctoral a D. Enrique Ángel García Angosto en la modalidad de "compendio de publicaciones".

Contra el presente acuerdo, que no agota la vía administrativa, podrá formular recurso de alzada ante el Sr. Rector-Magnífico de la Universidad Politécnica de Cartagena, en el plazo de un mes a partir de la notificación de la presente.

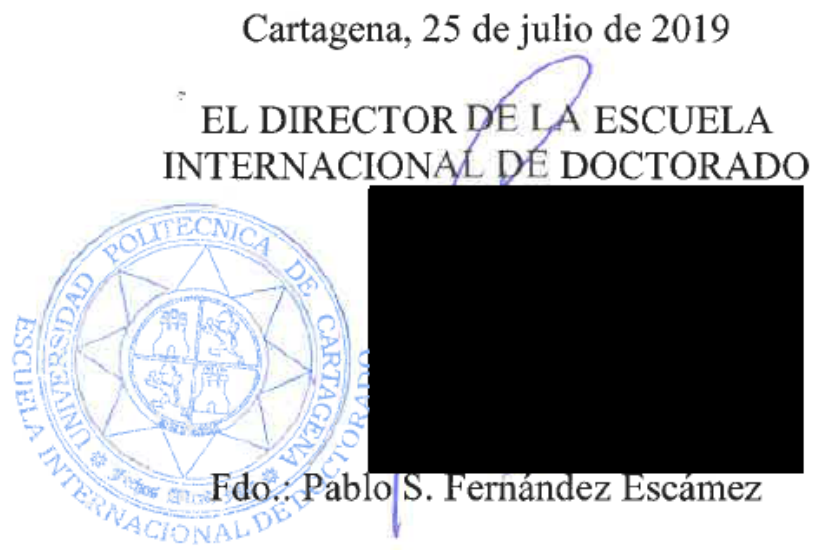




\section{Resumen en castellano}

El daño ocasionado por la radiación ionizante en órganos y tejidos debido a las pruebas médicas radiológicas es un factor de riesgo a la población que debe ser medido y evaluado por cualquier institución sanitaria. En esta tesis doctoral se expone una metodología de implantación, mejora y optimización de un sistema de gestión de dosis a paciente en pruebas médicas radiológicas a nivel corporativo así como, el control y medición de la dosis que reciben los profesionales sanitarios que realizan estas pruebas gracias a la creación de un dispositivo de medición de bajo coste, flexible y conectable a los sistemas corporativos de gestión de dosis de cualquier institución que lo implemente.

Se han publicado 4 artículos científicos en diferentes revistas con un índice de impacto JCR de primer cuartil [29] y de segundo cuartil [28, 38, 39] en los que se ha expuesto: (i) cómo se debe de abordar la implantación de cualquier sistemas de gestión de dosis en una institución sanitaria simple o compleja, (ii) la obtención de valores medios de medición de dosis en la modalidad de Tomografía Computarizada (TC) en distintos hospitales para su mejora y optimización. (iii) identificación de los valores anómalos extraídos de la media y que deberían de ser evaluados para evitar futuras radiaciones innecesarios al paciente y, (iv) control de las radiaciones recibidas, en tiempo real, por los profesionales sanitarios que realizan estas pruebas médicas radiológicas mediante la creación de un dispositivo que ha sido calibrado, certificado y testeado para su uso hospitalario para así ofrecer una completa supervisión y control de las radiaciones ionizantes a cualquier usuario del hospital, sea paciente o profesional sanitario. 


\section{Abstract}

The damage caused by ionizing radiation to organs and tissues due to radiological medical tests is a risk factor to the population that must be measured and evaluated by any health institution. This thesis provides a good framework for the prevention of ionizing radiation. This doctoral thesis presents a methodology for the implementation, improvement and optimisation of a system for managing patient doses in radiological medical tests at a corporate level, as well as the control and measurement of the doses received by the healthcare professionals who carry out these tests by creating a low-cost, flexible measuring device that can be connected to the corporate dose management systems of any institution that implements it.

Four scientific articles have been published in different journals with a JCR impact index of first quartile [29] and second quartile [28, 38, 39] in which it has been exposed: (i) how to approach the introduction of any dose management system in a simple or complex healthcare institution, (ii) the collection of average dose measurement values in the modality of Computed Tomography (CT) in different hospitals for its improvement and optimization. (iii) identification of the outliers extracted from the media and which should be evaluated in order to avoid future unnecessary radiation to the patient and, (iv) monitoring of the radiation received, in real time, by healthcare professionals who perform these radiological medical tests by creating a device that has been calibrated, certified and tested for hospital use in order to offer complete monitoring and control of ionizing radiation to any hospital user, patient or healthcare professional. 


\section{Índice general}

Îndice $\quad$ I

\begin{tabular}{ll|l} 
Agradecimientos & IV
\end{tabular}

Dedicatoria

1. Introducción 1

2. Objetivos $\quad 7$

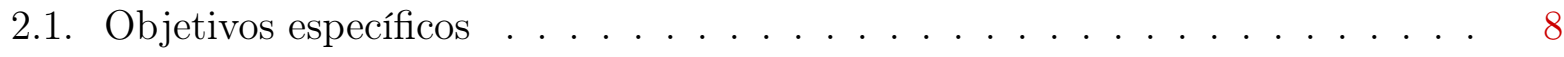

3. Estado del arte $\quad 11$

4. Artículos 16

4.1. Artículo 1: A Regional Solution for Patient Radiological Dose Management . 17

4.2. Artículo 2: Computed Tomography Radiation Dose in a Regional Survey . . 19

4.3. Artículo 3: Optimization of CT protocols using cause-and-effect analysis of outliers . . . . . . . . . . . . . . . . . . . . 21

4.4. Artículo 4: Ionizing Radiation Measurement Solution in a Hospital Environment 29

5. Resumen 62

5.1. A Regional Solution for Patient Radiological Dose Management . . . . . . . 62

5.1.1. Resumen ....................... 62

5.1.2. Materiales y métodos . . . . . . . . . . . . . . . . 62

5.1.3. Conclusiones ..................... . . 67

5.2. Computed Tomography Radiation Dose in a Regional Survey . . . . . . . . . 68

5.2.1. Resumen ........................ 68

5.2.2. Materiales y métodos . . . . . . . . . . . . . . . . . 68

5.2.3. Resultados y contribución . . . . . . . . . . . . . . . . . 71

5.2.4. Conclusiones . . . . . . . . . . . . . . . . . . 71

5.3. Optimization of CT protocols using cause-and-effect analysis of outliers . . . 72

5.3.1. Resumen . . . . . . . . . . . . . . . . . 72

5.3.2. Materiales y métodos . . . . . . . . . . . . . . 73 
5.3.3. Resultados y discusión . . . . . . . . . . . . . . . . . . 74

5.3.4. Conclusiones . . . . . . . . . . . . . . . . . . 77

5.4. Ionizing Radiation Measurement Solution in a Hospital Environment . . . . 79

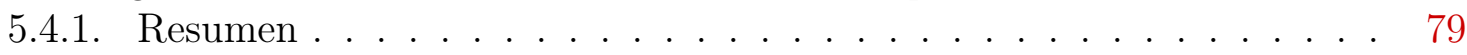

5.4.2. Materiales y métodos . . . . . . . . . . . . . . . . . 79

5.4.3. Resultados . . . . . . . . . . . . . . . . . . 86

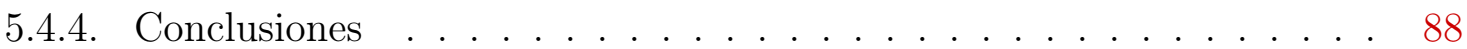

$\begin{array}{lr}\text { 6. Conclusiones } & 89\end{array}$

$\begin{array}{lr}\text { Bibliografía } & 96\end{array}$ 


\section{Agradecimientos}

La realización de una tesis doctoral es una tarea llena de dificultades, repleta de altibajos y muchos esfuerzos que, sumado a la pasión por aportar tu propio granito de arena a la comunidad científica, significa el mayor éxito académico en la actualidad. Cuando se comienza a realizar una carrera universitaria, un doctorado siempre es una meta muy lejana y sólo alcanzable para algunos privilegiados y, es por ello, que me siento muy afortunado por haber podido llegar a este momento. Esta aportación a la comunidad científica no podría realizarse sin las personas que han estado empujando desde el primer día, otras que ya no están desgraciadamente (y que también lo hicieron) y las últimas en incorporarse. Sin todas ellas nunca podría haber conseguido ser la persona que soy hoy en día y que me ha permitido presentar esta Tesis Doctoral por compendio de publicaciones.

Por ello, en primer lugar, quiero expresar mi total agradecimiento a Dr. Antonio Javier García Sánchez, Profesor Titular del Departamento de Tecnologías de la Información y las Comunicaciones, de la Universidad Politécnica de Cartagena, por aceptar y dirigir de una manera brillante esta Tesis Doctoral; su empuje hacia mi persona, su espíritu luchador y su incondicional entrega, ha conseguido que de una disciplina clásica como es la física y, una contemporánea como son las telecomunicaciones, enfocar artículos de un altísimo interés científico dando como resultado esta memoria de Tesis Doctoral. Ha sido muy curioso el ver cómo todo empezó siendo un profesor al que un día llamé a su puerta pidiendo un proyecto fin de carrera hace ya más de 15 años para convertirse en el gran amigo que es hoy en día. Por todo ello: GRACIAS.

Así mismo, quiero agradecer a mi codirector Dr. Alfredo Serna Berna, Jefe del Departamento de Radiofísica y Protección Radiológica del Área 2 del Servicio Murciano de Salud, que ha sabido integrar de una manera exquisita e innovadora su visión sobre el análi- 
sis de datos, radiaciones y seguridad del paciente para que, un campo como es el de la física médica, cupiese en un entorno cada vez más conectado siempre en beneficio del paciente y del profesional sanitario. Es por ello que te considero uno de los radiofísicos más influyentes de este país y un gran divulgador de la física médica. ¡Enhorabuena!

Quiero expresar también mi mas sincero agradecimiento a D. David Ramos Amores por sus aportaciones y participación activa en el desarrollo de esta tesis. Destacar, además, a todos mis compañeros de trabajo, sobre todo a D. Enrique Hernández Zurita y D. Vicente Caruana Denia, a los Managers con los que he trabajado en el pasado y con los que trabajo actualmente así como los directivos de la compañía GE Healthcare España que me han apoyado incondicionalmente en la realización de esta tesis y que también, sin su ayuda, no habría sido posible su realización.

Por último y no menos importante, dar las gracias a mis Padres y hermana puesto que no hubiera llegado a ser lo que soy sin su entrega, esfuerzo y amor continuo; También a mi mujer, Yésica, que me sigue dando esa dosis diaria de cariño y compresión necesaria par seguir adelante y finalmente, a mis tres hijas: Lola, Lucía y Elena que me dan la fuerza necesaria para enfrentarme a nuevos retos cada día. 
A la memoria de D. Francisco Madrid Sabio y Dr. Felipe García Sánchez, por sus consejos y apoyo incondicional. Nunca os olvidaré. 


\section{Introducción}

El ser humano no dispone de facultades sensoriales para detectar las radiaciones, aunque sí de sufrir sus efectos generalmente nocivos. El mecanismo de acción de la radiación ionizante es su capacidad para ionizar los átomos, y por tanto derivar un efecto que puede producirse a corto, medio o largo plazo, cuya gravedad será función del tipo de radiación, dosis de radiación recibida y duración en el tiempo. En contrapartida, esta misma radiación ionizante puede salvarnos la vida ya que su uso en el campo de la medicina permite a los profesionales sanitarios diagnosticar enfermedades o, incluso, convertirse en una herramienta para curarnos. Dentro de las radiaciones ionizantes, destaca los denominados Rayos X debido a que es la radiación más conocida por el público y ampliamente utilizada en medicina en las pruebas radiológicas. En la Figura 1.1 se muestra el rango del espectro de radiación que va desde las ondas de radio convencionales (radiación no ionizante) hasta los rayos gamma (radiación ionizante).

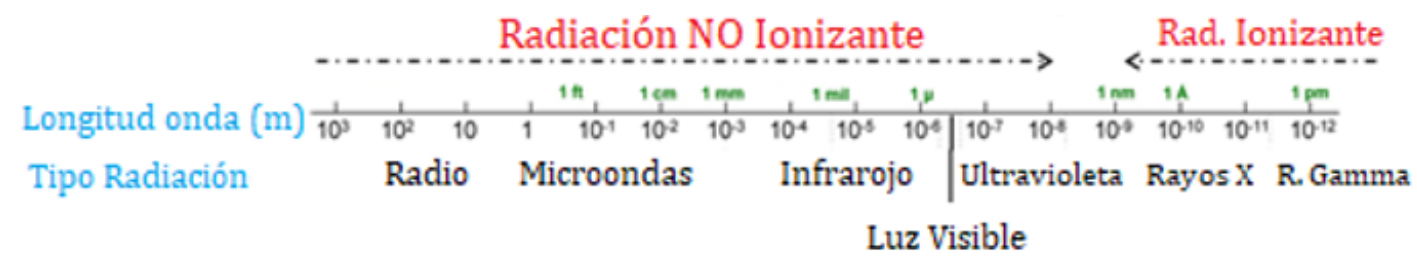

Figura 1.1: Clasificación de las radiaciones en el espectro

Las radiaciones tienen un origen natural, aunque también pueden producirse artificialmente en forma de radioisótopos o, incluso, los generadores de Rayos X. Las radiaciones ionizantes están formadas por tres tipos de partículas clasificadas de la siguiente manera: 


\section{- Partículas Alfa $(\alpha)$ :}

Compuesto por dos protones y dos neutrones. Poseen una capacidad de penetración pequeña, aunque dentro del organismo pueden ser bastante nocivos.

\section{- Partículas Beta $(\beta)$ :}

Compuesta por un electrón. Posee también una capacidad de penetración pequeñamedia y, al igual que las partículas alfa, dentro del organismo son bastante nocivas.

\section{- Partículas Alfa $(\gamma)$ :}

Compuesta por fotones muy energéticos. Posee un poder de penetración superior al de las partículas alfa y beta superando muy fácilmente la piel por lo que puede generar graves daños en los órganos internos. Los Rayos X tienen menor capacidad de penetración que los rayos gamma, pero están compuestos también por fotones altamente energéticos.

En la siguiente Figura 1.2 se muestra un ejemplo del poder de penetración de estas radiaciones en diferentes tipos de materiales.

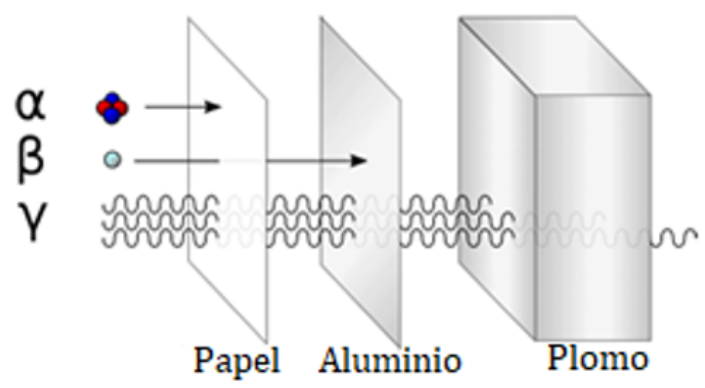

Figura 1.2: Poder de penetración de las partículas $\alpha, \beta, \gamma$

Los efectos de esta radiación ionizante en el organismo vienen determinados por el nivel de radiación al ha sido expuesto el paciente durante el estudio clínico, conociéndose dos efectos secundarios que dependerán de la cantidad de radiación absorbida por nuestro organismo. 
Si la radiación supera un umbral específico, los efectos en el paciente se presentan a corto plazo, lo que se conoce como efectos determinísticos. Véase como ejemplo en la Figura 1.3 las consecuencias de estos umbrales de radiación como pueden ser: quemaduras superficiales, pérdida de cabello etc.

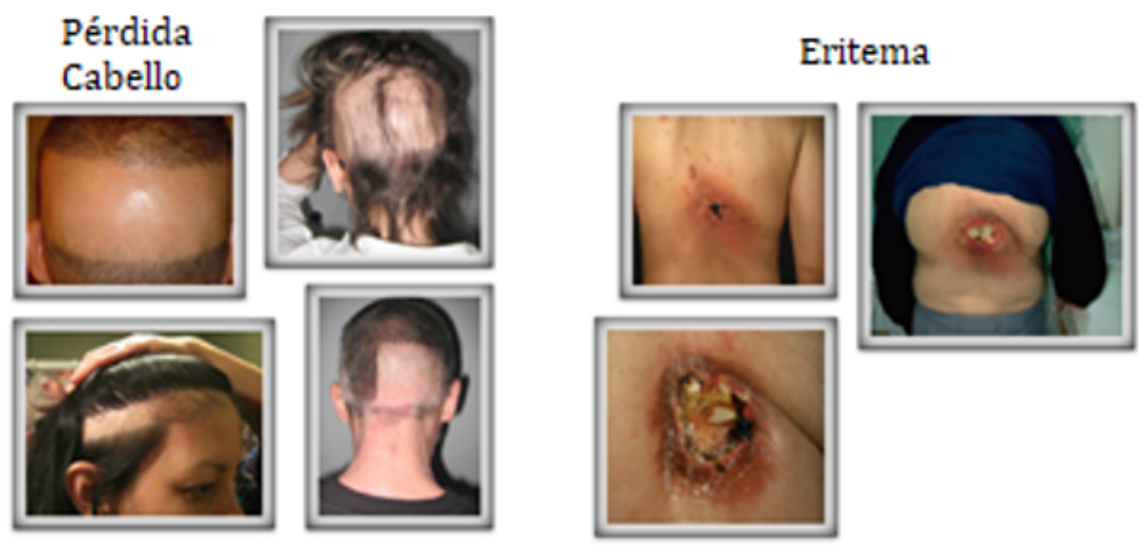

Figura 1.3: Efectos determinísticos de la radiación ionizante

Por el contrario, si la radiación ha sido menor que ese umbral existe la posibilidad que los efectos aparezcan en el medio y largo plazo en forma generalmente de tumores. Estos se conocen como efectos estocásticos y su origen viene determinado por la palabra griega Stoke (azar) y pone de manifiesto esta aleatoriedad ya que no se puede vaticinar si esa radiación va a tener consecuencias o no para nuestra salud en el futuro. En la Figura 1.4 se muestra un diagrama de los efectos biológicos de las radiaciones en las células de nuestro organismo diferenciando los dos mayores efectos: determinísticos y estocásticos.

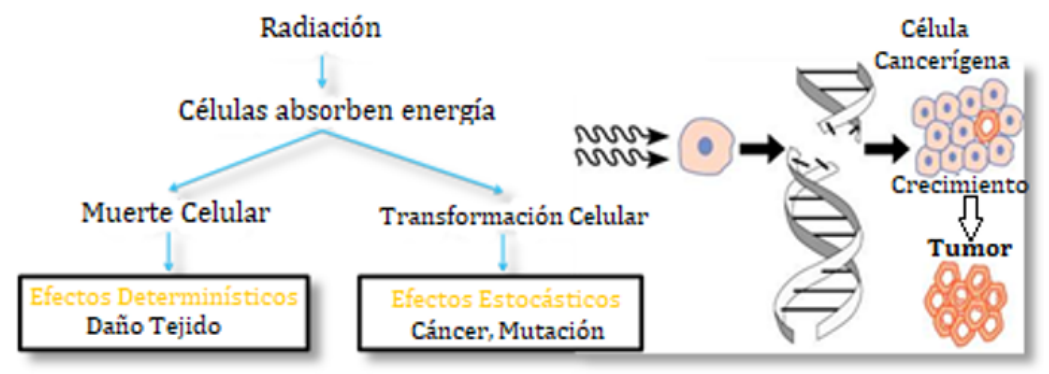

Figura 1.4: Efectos biológicos de la radiación ionizante en las células 
La contrapartida positiva a los efectos nocivos de la radiación es su poder de diagnóstico en el ámbito de la medicina; la calidad diagnóstica de una imagen es directamente proporcional a la cantidad de radiación. Por tanto, debe de existir siempre un compromiso entre la calidad diagnóstica de una imagen y la cantidad de radiación asociada para su obtención (recordemos que la radiación en si misma es nociva para los humanos). El objetivo de los profesionales sanitarios es minimizar los riesgos de la exposición a esta radiación mientras que se mantenga una calidad de imagen mínima para su diagnosis. Este principio se conoce como ALARA (As Low As Reasonably Achievable) y es seguido por los profesionales sanitarios en todo el mundo cuando la radiación ionizante debe ser aplicada a humanos, animales o materiales basándose siempre en los principios de la radioprotección.

Entre la multitud de tipos de pruebas radiológicas médicas, la que más crecimiento está experimentando es la técnica de tomografía computarizada (TC). Un escáner de Tomografía computarizada (TC) es una máquina de diagnóstico por imagen utilizada en todo el mundo basada en el uso de rayos X incididos sobre el cuerpo humano. Un TAC consiste en un tubo abierto dónde se coloca al paciente y sobre él rota el tubo de rayos X en las distintas zonas del cuerpo a examinar.

En este contexto se requiere un control exhaustivo de la radiación que reciben los pacientes y personal sanitario cuando son tratados y evaluados dentro de un sistema de salud fijado en la directiva Europea 2013/59/EURATOM [4]. Para contribuir a esta tarea, en los últimos años han surgido plataformas software específicas que recopilan toda la información de dosis que ha recibido un paciente mediante las imágenes diagnósticas. Estas imágenes contienen la cantidad de dosis irradiada al paciente lo que permite crear registros personalizados del historial dosimétrico de los mismos. 
Para poder registrar la dosis que ha recibido cada paciente, los diferentes equipos se conectan a un sistema automático de gestión de dosis de forma directa (conectándose directamente al equipo) o indirecta (conectándose al repositorio de imágenes radiológicas). La comunicación con las modalidades se lleva a cabo de diferentes formas dependiendo de las posibilidades de conexión de cada equipo, de forma que los datos de dosis sean recuperables en la mayor parte de los casos, utilizando para ello el estándar de protocolo médico DICOM (Digital Imaging and COmmunications in Medicine).

A partir de este protocolo de transferencia de imágenes médicas, los datos pueden ser clasificados de mayor a menor calidad, describiéndose a continuación los siguientes tipos y estándares de conexión:

\section{- DICOM Headers:}

Consiste en la obtención de los datos mediante su extracción de las cabeceras DICOM de las propias imágenes generadas por el equipo.

\section{- DICOM Structured Report (SR):}

A través de este estándar el equipo envía al sistema de control de dosis un informe estructurado con la información del estudio. Los mensajes enviados son menos pesados que en el tipo anterior pero la información que contiene suele ser más limitada.

\section{- DICOM MPPS:}

Similar a DICOM SR pero de mayor antigüedad. Este estándar suele contener información muy limitada dentro de un informe estructurado con los datos básicos del examen realizado.

La realidad con la que nos encontramos en cualquier servicio de salud es que coexisten equipos de diferentes fabricantes, tecnologías y gama lo cual implica numerosos procesos de integración dependiendo del fabricante. Así, un sistema automático de gestión de dosis 
puede, a priori, resolver este problema. Sin embargo, éste debe ser implantado a nivel organizativo, permitiendo que en cada centro hospitalario se puedan estandarizar las prácticas, establecimiento niveles de dosis globales de referencia y que no se vea penalizado el paciente por su ubicación geográfica para su tratamiento específico dentro de la misma organización sanitaria.

Pero la radiación no solo afecta al paciente, sino también a los profesionales que realizan y diagnostican las pruebas. Ellos también están expuestos a la radiación ionizante dispersa que las mismas pruebas emiten al entorno y que son absorbidas por ellos mismos. Cabe destacar el caso de los cardiólogos cuando realizan procedimientos que utilizan Rayos X como son en las salas de Intervencionismo. 


\section{Objetivos}

En esta sección se van a enumerar los objetivos que se persiguen en esta tesis, intrínsecamente relacionados con la disertación realizada en la Introducción de este documento.

Los objetivos principales quedan enumerados de la siguiente manera:

1. Implementación de una metodología para que los organismos de salud puedan abordar el control dosimétrico de la población en el entorno hospitalario. Para ello, en la publicación "A regional solution for patient radiological dose management" se contribuye con las aportaciones necesarias para que toda organización sanitaria pueda implementar con éxito un sistema corporativo de gestión de dosis a paciente.

Una vez conocida la metodología, se debe abordar la implantación de un sistema automatizado de registro de dosis con el objetivo de poder realizar el control dosimétrico personalizado al paciente dentro del sistema sanitario, estableciendo para ello mecanismos de mejora continua en las prácticas diarias de los profesionales sanitarios que realizan los estudios radiológicos.

Como se ha comentado en la Introducción, es la modalidad de TAC la que genera más del $50 \%$ de la radiación recibida por el paciente en el sistema de salud mundial, por tanto se hace necesario abordar esta modalidad como prioritaria dentro del sistema corporativo de gestión de dosis:

2. Obtención y explotación de los datos generados por los sistemas automáticos de gestión de dosis atendiendo a sus usos y beneficios que aportan a la organización. En la publicación "Computed tomography radiation dose in a regional survey" se 
analizan los estudios más comunes de la modalidad de TAC como es el Cráneo, Tórax o Abdomen-Pelvis ofreciendo métodos de control y estandarización de prácticas.

Una vez que se han estandarizado las prácticas clínicas dentro de una modalidad radiológica específica, en este caso TAC, es necesario abordar los posibles errores humanos o tecnológicos que impliquen una dosis por exceso o por defecto a un paciente determinado, es por lo que el siguiente objetivo se centra en:

3. Identificación y análisis de los valores anómalos de la distribución de las dosis radiadas a pacientes para la mejora de procesos dentro del sistema de salud. Por ello, la publicación "Optimization of CT protocols using cause-and-effect analysis of outliers" se focaliza en cómo identificar estos valores anómalos, así como su procedencia para poder evitar una mala praxis dentro la práctica clínica diaria.

Un organismo de salud puede afirmar que realiza un control completo dosimétrico dentro de sus hospitales o centros asociados siempre y cuando se está en disposición de monitorizar, además de las dosis a paciente, la dosis recibida por los profesionales sanitarios que realizan esos estudios y que, en menor medida, están expuestos a estos riesgos. Por consiguiente, el último objetivo pone de manifiesto este control mediante:

4. Creación de una solución que permita la medición de dosis personal y de área en entornos hospitalarios. En la publicación "Ionizing Radiation Measurement Solution in a Hospital Environment" se realiza un exhaustivo estudio de los métodos actuales de medición dosimétrica personal contribuyendo con una solución que integra un prototipo real, calibrado, y validado, de medición de radiación ionizante en tiempo real dirigido a los profesionales sanitarios.

\subsection{Objetivos específicos}

Una vez establecidos los objetivos generales, se van a describir los objetivos específicos relacionados con cada una de las publicaciones de esta tesis: 


\section{Primera publicación}

Artículo: "A regional solution for patient radiological dose management"

I Estandarización de protocolos: Agrupación y mapeado frente a una lista estándar de los distintos protocolos de cada sistema TAC.

II Mecanismos de establecimiento de DRLs: Creación de los niveles de referencia para cada modalidad radiológica.

III Mecanismos de optimización de dosis: Identificación de procesos de mejora en los equipos que superen los umbrales de DRL (Diagnostic Reference Level) establecidos.

\section{Segunda publicación}

Artículo: "Computed tomography radiation dose in a regional survey"

I Mecanismo de establecimiento de DRLs en la modalidad de TAC: Creación de niveles de referencia en la modalidad de TAC para los protocolos más usados en un área de salud determinada (regional).

II Identificación de protocolos optimizables: Estandarización de la dosis en toda la organización sanitaria para la modalidad de TAC identificando mejoras en los protocolos con el objetivo de reducción de dosis a paciente.

\section{Tercera publicación}

Artículo: "Optimization of CT protocols using cause-and-effect analysis of outliers"

I Metodología de análisis e identificación de valores anómalos: Método de obtención y clasificación de los valores anómalos de la distribución, así como la identificación de las causas que los generan. 
II Optimización de protocolos en TAC a partir del análisis de causa y efecto de los valores anómalos mediante la creación de un diagrama de causa efecto de estos valores anómalos para su posterior optimización del protocolo donde se aplique.

\section{Cuarta publicación}

Artículo: "Ionizing Radiation Measurement Solution in a Hospital Environment"

I Diseño y desarrollo de una solución dosimétrica para mejorar la protección frente a radiación del personal sanitario: Esta solución abarca desde el dispositivo que captura y transmite los datos a una Base de Datos vía 3G/Wifi, la gestión de los datos, hasta una aplicación móvil que identifica a cada miembro del personal médico en el sistema y le informa de su nivel de dosis acumulada.

II Desarrollo de un dispositivo de medición de dosimetría personal y de área: Evaluación de la dosimetría personal y de área en la actualidad creando un prototipo que ofrece una solución de bajo coste y de código abierto que suple las deficiencias de los sistemas actuales de medición en entorno hospitalario.

III Calibración, evaluación y puesta en marcha en un hospital público: Calibración del prototipo creado en el centro nacional de dosimetría (CND) y evaluación de resultados en un entorno real para un hospital público de la Región de Murcia. 


\section{Estado del arte}

Un sistema público o privado de salud se compone en su mayor medida de varios hospitales o centros de salud ubicados dentro de una misma región estando todos ellos gestionado por un organismo central. En la Figura 3.1 se ilustra un ejemplo de la distribución de un sistema de salud gestionado por un organismo central.

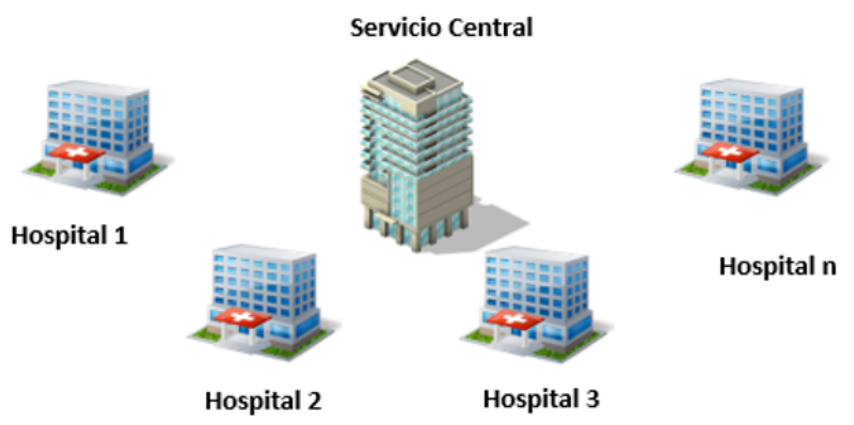

Figura 3.1: Distribución estándar de un sistema de salud

Como se ha comentado anteriormente, la directiva europea 2013/59/EURATOM obliga a todos los sistemas públicos de salud de la Unión Europea a realizar un control y seguimiento de las radiaciones ionizantes emitidas por las exploraciones radiológicas y que reciben los pacientes de estos sistemas sanitarios. Actualmente la directiva no contempla cómo implementar un sistema de gestión de dosis en un organismo público sanitario sino simplemente se limita a indicar que la radiación debe de ser controlada y gestionada de una manera eficiente. 
En la actualidad, en España sólo la Región de Murcia posee un sistema corporativo de gestión de dosis implantado en toda la comunidad, dentro del Programa de Seguridad al Paciente de la CARM, que ha ayudado a reducir en cerca de un $35 \%$ las dosis a paciente $[6]$.

Para poder realizar un seguimiento a estas pruebas y poder así evitar en la manera de lo posible una exposición excesiva a la radiación ionizante, esta directiva europea contempla la necesidad de implementar un software automatizado de registro de dosis. Bajo el paraguas de estos paquetes software, muchos son los beneficios que se obtienen registrando automáticamente la dosis que reciben los pacientes [26], además de ser una buena herramienta para realizar un control y establecimiento de niveles de referencia dosimétrica dentro de las instituciones que las implementen [36], [34], [23].

Tal y como se ha comentado anteriormente, el mayor riesgo que una exploración de TAC produce es la exposición a la radiación ionizante, en este caso los Rayos X. A pesar de ser sólo el $15 \%$ de todas las pruebas radiológicas en un sistema sanitario, contribuye en más del $50 \%$ de la radiación suministrada a la población [25]. A modo de ejemplo, una exploración de TAC de abdomen contiene la misma dosis que la suma de 60 radiografías de pecho [17]. En la Figura 3.2 se muestra una comparación de los niveles de dosis que recibe la población.

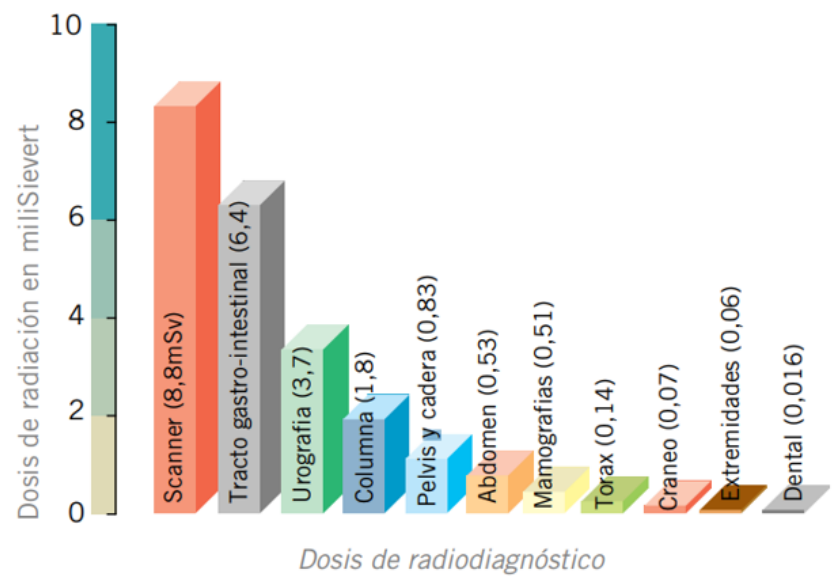

Figura 3.2: Equivalencia de dosis efectiva en Radiodiagnóstico (Fuente: CSN) 
Mientras que muchos radiofísicos y personal médico son conscientes en que existe un pequeño riesgo potencial en las exploraciones de TAC o cualquier fuente de rayos X, también son conscientes que el TAC es una herramienta muy potente de diagnóstico que en la mayoría de las ocasiones es usada de manera apropiada para el cuidado del paciente.

Por ello, es necesario un seguimiento y optimización exhaustiva de la dosis de radiación a paciente, requiriendo además una completa recopilación de los datos de los mismos. Se deben desarrollar programas de reducción de dosis en TAC para asegurar que los pacientes reciben la dosis mínima necesaria para el diagnóstico. Para ello se recomienda la utilización de parámetros objetivos como son DLP y CTDIvol [30]. CTDIvol(mGy) expresa la densidad de radiación recibida para un determinado corte axial referenciado sobre un fantoma estandarizado de $16 \mathrm{~cm}$ (fantoma de cabeza) o de $32 \mathrm{~cm}$ (fantoma de cuerpo). El parámetro DLP (mGy.cm) multiplica el valor de CTDIvol por la longitud del estudio en centímetros. En la Figura 3.3 se puede apreciar esta diferenciación de los parámetros.

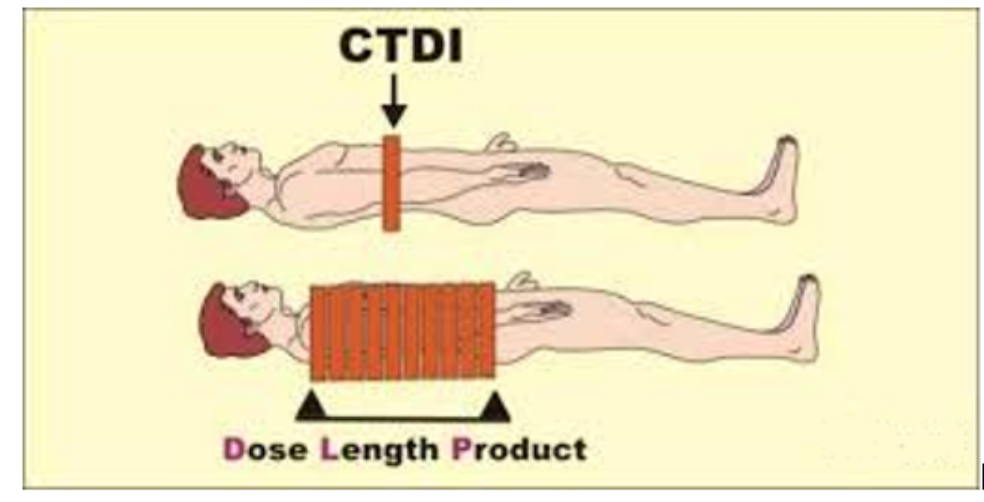

Figura 3.3: Parámetros CTDIvol y DLP (Fuente: Sprawls.org)

La dosis efectiva, que estima el riesgo biológico, se calcula mediante el parámetro DLP multiplicado por un factor que depende de la zona específica anatómica irradiada. En la Tabla 3.1 se muestran el valor de este factor el cual depende de la edad del paciente: 


\begin{tabular}{|l|l|l|l|l|l|}
\hline \multicolumn{7}{|c|}{ Dosis efectiva por DLP $\left(\mathrm{mSv} \mathrm{mGy}^{-1} \mathrm{~cm}^{-1}\right)$} \\
\hline Región del cuerpo & 0 años & 1 año & 5 años & 10 años & Adulto \\
\hline Cabeza & 0.011 & 0.0067 & 0.0040 & 0.0032 & 0.0021 \\
\hline Cuello & 0.017 & 0.012 & 0.011 & 0.0079 & 0.0059 \\
\hline Pecho & 0.039 & 0.026 & 0.018 & 0.013 & 0.014 \\
\hline Abdomen-Pelvis & 0.049 & 0.030 & 0.020 & 0.015 & 0.015 \\
\hline
\end{tabular}

Tabla 3.1: Factores para el cálculo de la dosis efectiva en órgano[41]

A partir de estos parámetros es posible establecer unos valores de referencia llamados DRL (Dose Reference Level) los cuales fueron introducidos como concepto en el año 1996 [11] y de una forma más masiva en 2007 [12] en forma de "restricciones". Posteriormente el concepto de DRL queda definido como el nivel superior o inferior de dosis administrada a paciente en la prueba de imagen médica que haya sido obtenida por radiaciones ionizantes [10].

Los niveles de DRL no deben ser tomados como límites de dosis a un paciente concreto ni su aplicación como criterio único de optimización de dosis [11]. Los DRLs deben ser una herramienta para identificar en qué tipo de pruebas existe la oportunidad de mejora y posible optimización [11]. En este sentido, se han publicado numerosas encuestas nacionales en diferentes países para abordar el establecimiento de los niveles de referencia en las pruebas TAC [2, 22, 31, 33, 35, 37, 40], incluso encuestas globales por continentes [32]. Destacar que muchas de las encuestas realizadas han sido únicamente una actualización de los datos que se tenían de finales del siglo XX [27], [3]

Otro de los beneficios de estos sistemas de registro de dosis son la gran cantidad de datos que se obtienen y, en donde el parámetro estadístico mediana comienza a ser relevante en detrimento de los cálculos de niveles de referencia basados en pocos estudios y en morfologías de paciente determinadas [42]. Sin embargo, cuando los estudios y los pacientes no han sido seleccionados correctamente salen a la luz datos anómalos. Por norma general muchos estudios de establecimiento de niveles de referencia se centran en la obtención de estos valores 
teniendo en cuenta estos datos anómalos, pero muy pocos se centran en las causas de los mismos [24]. El estudio de estos datos anómalos es relevante y proporciona información útil sobre mala praxis y sus posibles correcciones [15].

Para estar en disposición de afirmar que un sistema de salud está gestionando apropiadamente las radiaciones ionizantes en su organización se requiere incluir otro grupo objetivo no menos importante: el personal sanitario. En la Tabla 3.2 se muestra el porcentaje de los profesionales sanitarios que exceden sus límites de dosis anuales dependiendo de la función que desempeñen.

\begin{tabular}{|l|l|l|l|l|}
\hline Tipos de trabajo & Facultativos & A.T.S. & Técnicos & Otros \\
\hline Radiología Ambulatorio & $0,0 \%$ & $0,4 \%$ & $0,0 \%$ & $0,0 \%$ \\
\hline Radiología Hospital & $2,7 \%$ & $1,4 \%$ & $0.5 \%$ & $0.4 \%$ \\
\hline Radiología Vascular & $24.1 \%$ & $5.9 \%$ & $2.9 \%$ & $1.5 \%$ \\
\hline Radioterapia & $0.1 \%$ & $2.6 \%$ & $0,4 \%$ & $0.7 \%$ \\
\hline Medicina Nuclear & $1.7 \%$ & $50,7 \%$ & $36.6 \%$ & $13.0 \%$ \\
\hline Intervencionismo & $2.2 \%$ & $0.4 \%$ & $0.0 \%$ & $0.1 \%$ \\
\hline Otros & $0.6 \%$ & $0.3 \%$ & $0.0 \%$ & $0.0 \%$ \\
\hline
\end{tabular}

Tabla 3.2: Porcentaje de profesionales que exceden los limites de dosis anuales

El $R D$ 783/2001 [18] de la legislación española define a un profesional sanitario expuesto a aquel que llevando su labor a cabo y bajo determinadas circunstancias tiene riesgo de exposición a la radiación ionizante. Atendiendo a la dosis efectiva, los trabajadores radioexpuestos son divididos en dos categorías; la categoría A y la categoría B dependiendo de si la dosis efectiva recibida es superior a 6 mSv por año (grupo A) o no (grupo B). En la Tabla 3.3 se ilustra un resumen de la dosis efectiva según categoría y zona del cuerpo irradiada.

\begin{tabular}{|l|l|l|l|}
\hline Clasificación del Personal & Dosis Efectiva & Dosis en cristalino & Dosis en piel \\
\hline Trabajor expuesto Cat. A & $>6 \mathrm{mSv} /$ año & $>45 \mathrm{mSv} /$ año & $>150 \mathrm{mSv} /$ año \\
\hline Trabajador expuesto Cat. B & $<6 \mathrm{mSv} /$ año & $<45 \mathrm{mSv} /$ año & $<150 \mathrm{mSv} /$ año \\
\hline Trabajador NO expuesto & $<1 \mathrm{mSv} /$ año & $<15 \mathrm{mSv} /$ año & $<50 \mathrm{mSv} /$ año \\
\hline
\end{tabular}

Tabla 3.3: Clasificación de trabajadores. Dosis según categoría y zona del cuerpo irradiada 
Todos los profesionales del grupo A deben de ser monitorizados con un dosímetro personal e intransferible. En la actualidad existen diferentes tipos de dosímetros que dependen de su modo de lectura de la información de dosis. Por una parte, existen aquellos equipos que proporcionan la información de dosis a través de otros procesos como son: Dosímetros Termoluminiscentes [21] de película [8], radiofotoluminiscente [14] de luminiscencia ópticamente estimulada [5] y, por otra parte, aquellos que proporcionan una lectura directa [7].

Además de la dosimetría personal que afecta a los trabajadores sanitarios, dentro de un hospital existen zonas de riesgo de radiación ionizante. En particular, aquellas zonas cercanas al departamento de Medicina Nuclear donde los pacientes son tratados con radiofármacos que hacen que el propio paciente sea una fuente adicional de radiación. Con objeto de controlar esta radiación se suelen instalar dosímetros de área, los cuales se pueden clasificar en dos categorías:

\section{- Detectores de gas:}

basados en el fenómeno de la ionización causados por una partícula cuando atraviesa el gas noble ubicado entre dos electrodos sometidos a una diferencia de potencial $[9,13,16]$.

\section{- Detectores de estado sólido:}

detectores en los que un material semiconductor (silicio o germanio) constituye el medio detector [19, 20] 
4. Artículos 
4.1. Artículo 1: A Regional Solution for Patient Radiological Dose Management 


$$
\text { :三 Download Share Export }
$$

\section{A regional solution for patient radiological dose management}

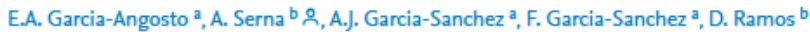

田 Show more

https://doi.org/10.1016/j.ejmp.2016.07.717

Get rights and content

Purpose

To highlight a novel methodology for patient dose management of radiological examinations in a regional public health framework.

Material and methods

DoseWatch-GE is a multivendor and multimodality patient dose management software for radiological examinations. The framework in this study is a Region of Spain with 10 hospitals and 1.5 Million population. Dose indexes and examination protocols are recorded in individual patient files. Our methodology is divided into three foundations: (1) standardization of protocols, (2) Setting of Regional Diagnostic Reference Levels (RDRL), and (3) dose optimization.

Results

Nowadays, 60 devices from 10 public hospitals are monitored: 13 CT's, 9 Interventional, 9 Mammo and 23 conventional. Every month the system is collecting approximately: $9000 \mathrm{CT}$, 800 Interventional, 2500 Mammo and 33000 conventional examinations.

Standardization of protocols must be the first step because examinations nomenclature is highly variable among both manufactures and hospitals. We have established a master protocol list as reference for local protocols, thus allowing coherent data analysis.

RDRL can be established and updated thanks to the massive amount of data available from a wide variety of equipment. This data might serve for future national DRL, currently not available.

Dose optimization is supported by a multidisciplinary Dose Committee (radiologist, medical physicist, technologist, administration and application specialists), actively searching for dose reduction opportunities, based on comparative analysis with international DRL's and among similar equipments.

\section{Conclusion}

We conclude that dose management systems might play an important role in the radiological patient safety task.

Disclosure

None.

$<$ Previous

Next $>$

Special issue articles Recommended articles Citing articles $(0)$

View Abstract

ELSEVIER About ScienceDirect Remote access Shopping cart Advertise Contact and support Terms and conditions Privacy policy

We use cookies to help provide and enhance our service and tailor content and ads. By continuing you agree to the use of cookies. Copyright (c) 2019 Elsevier B.V. or its licensors or contributors. ScienceDirect @ is a registered trademark of Elsevier B.V. 
4.2. Artículo 2: Computed Tomography Radiation Dose in a Regional Survey 
:三 Download Share Export

Physica Medica

Volume 32, Supplement 3, September 2016, Page 287

\section{Computed tomography radiation dose in a regional survey}

A. Serna ${ }^{a}$ ㅇ, E.A. Garcia-Angosto b ${ }^{\text {, A.J. Garcia-Sanchez }}{ }^{\text {b }, ~ F . ~ G a r c i a-S a n c h e z ~}{ }^{\text {b }}$, D. Ramos ${ }^{a}$

田 Show more

https://doi.org/10.1016/j.ejmp.2016.07.106

Get rights and content

Purpose

To evaluate the patient dose in computed tomography (CT) examinations and contribute to the stablishment of dose reference levels using a dose management system.

Material and methods

Data from 5 CT hellical multi-slice scanners (16-128 slices) in 3 public hospitals were surveyed (4 Siemens, 1 General-Electric) during 3 months. Three typical examinations were selected: head (1445 cases), thorax (579 cases) and abdomen-pelvis (1055 cases). GE-Dosewatch was used to register patient dose indexes, CTDIvol and DLP, and the technical parameters. The statistical analysis was done in Matlab.

Results

Both the CTDIvol and the DLP data approximate well to a log-normal distribution function whereas the scanned length fits better to a normal distribution.

Median CTDIvol of head scans ranged 33.0-63.8 mGy, thorax 6.7-9.7 mGy and abdomen-pelvis 10.0-12.1 mGy. Median DLP of head scans ranged 527$1162 \mathrm{mGy} \mathrm{cm}$, thorax 218-334 mGy cm and abdomen-pelvis $383-453 \mathrm{mGy} \mathrm{cm}$.

We noticed that same CT model scanners use different technical examinations parameters, resulting in dose variations up to $30 \%$. A dose optimization process was initiated to standardize the scanning protocols, thus expecting a dose reduction around $20 \%$ in some cases.

Patient size selection was not deemed necessary due to the high number of cases per examination, more than 100. A drawback of this massive data is the presence of extreme outliers, and thus data filtering is mandatory.

Conclusion

Dose management systems provide an efficient tool to overview and optimize radiological dose levels.

Disclosure

None.

$$
<\text { Previous }
$$

Special issue articles Recommended articles Citing articles $(0)$

View full text

ELSEVIER About ScienceDirect Remote access Shopping cart Advertise Contact and support Terms and conditions Privacy policy

We use cookies to help provide and enhance our service and tailor content and ads. By continuing you agree to the use of cookies. Copyright (C) 2019 Elsevier B.V. or its licensors or contributors. ScienceDirect @ is a registered trademark of Elsevier B.V. 
4.3. Artículo 3: Optimization of CT protocols using cause-and-effect analysis of outliers 
Original paper

\section{Optimization of CT protocols using cause-and-effect analysis of outliers}

Alfredo Serna $^{\mathrm{a}, *}$, David Ramos ${ }^{\mathrm{a}}$, Enrique Garcia Angosto ${ }^{\mathrm{e}}$, Antonio Javier Garcia Sanchez ${ }^{\mathrm{b}}$, Maria A. Chans ${ }^{c}$, Jose M. Benedicto Orovitg ${ }^{c}$, Vicente Puchades Puchades ${ }^{\mathrm{a}}$, Juan F. Mata Colodro ${ }^{a}$

a Medical Physics and Radiation Protection Department, Hospital General Universitario Santa Lucia, Cartagena, Spain

b Department of Information and Communication Technologies, Universidad Politécnica de Cartagena, Spain

'Diagnostic Radiology Department, Hospital General Universitario Santa Lucia, Cartagena, Spain

'General Electric Healthcare, Universidad Politécnica de Cartagena, Spain

\section{A R T IC L E IN F O}

Keywords

CT protocol optimization

Outliers

Cause and effect analysis

\section{A B S T R A C T}

The aim of this study was to implement an outlier marking and analysis methodology to optimize CT examination protocols.

CT Head examination data, including dose metrics along with technical parameters, were stored in an automatic dose registry system. Reference dose metrics distribution was obtained throughout a 1-year period. Outlier thresholds were calculated taking into account the specific shape of the distribution, by using a robust measure of the skewness; the medcouple parameter. Subsequently, outliers from a 4-month period were marked and Cause-and-Effect analysis was carried out by a multidisciplinary dose committee.

Reference Dose metrics distributions were obtained from 3690 CT Head examinations. Both CTDIvol and DLP showed a certain degree of skewness, with a medcouple value of 0.05 and 0.11 , respectively. All of the upperoutliers fell within 3 identifiable groups of causes, ordered by relative importance: i) inadequate protocol selection, ii) arms or objects in the field-of-view, and iii) abnormal scanning region diameter. Regarding the loweroutliers, $90 \%$ were attributable to the inclusion of additional series in the original head protocol and the remaining $10 \%$ to unknown causes. Also, a general Cause-and-Effect diagram for outliers was elaborated.

While the Dose Reference Level method applies to the general performance of a CT protocol and allows comparison with other centers, the outlier method represents a step further in the optimization process. The proposed method focuses on detecting incorrect utilization of the CT, which mainly arises from inadequate knowledge of CT technology.

\section{Introduction}

During the past two decades, radiography and angiography/ fluoroscopy rates remained relatively stable, whilst computed tomography (CT) examinations tripled [1]. In Europe an steady increase has also been observed, going from 86 CT examinations per 1000 inhabitants in 2006 to 223 CT examinations in 2016 [2]. This fact has produced an increase in patient exposure to radiation, with the mean per capita effective dose rising from $1.2 \mathrm{mSv}$ in 1996 , to $2.3 \mathrm{mSv}$ in 2010 [3]. CT is the radiological technique most in demand at this time, contributing to approximately $60 \%$ of the total radiation doses received by the population from medical examinations. It is estimated that $2 \%$ of future cancers will result from current imaging use if imaging continues at current rates [4], taking special considerations with pediatric patients [5]. Therefore, it is necessary to adequately justify and optimize radiological examinations.

In addition, the increased technological complexity of radiological equipment, such as the tube current modulation in CT, makes the continuous training of professionals necessary, in order to avoid patients receiving unnecessary doses of radiation [6].

The growth in advanced diagnostic imaging has almost certainly contributed to both improved patient care processes and outcomes, although the possible detriment to health and the economic cost must be stressed. The need for medical exposure control has been dealt with in European legislation, with the result being that CTs must have the ability to produce enough information to evaluate patient radiation doses [7]. This information could then be incorporated into a patient dose history [8-10]. Automatic dose registry systems can receive data from all different radiological modalities and generate individual patient records, also providing visualization and analysis tools of the dose

\footnotetext{
- Corresponding author at: Medical Physics and Radiation Protection Department, Hospital General Universitario Santa Lucia, 30202 Cartagena, Spain. E-mail address: alfredo.serna@carm.es (A. Serna).
}

https://doi.org/10.1016/j.ejmp. 2018.10.010

Received 25 July 2018; Received in revised form 4 October 2018; Accepted 8 October 2018

Available online 16 October 2018

1120-1797/ (c) 2018 Associazione Italiana di Fisica Medica. Published by Elsevier Ltd. All rights reserved. 
metrics used on each radiological modality.

The reference dose level methodology in radiological exploration (DRL) has shown its value in the optimization process, using the median of the different dose metrics [11-14]. Nowadays, a huge amount of radiological exposure information is available, making patient selection based on their weight for the calculation of the local dose reference levels less important, since the median is obtained for the whole patient population instead [15]. However, in this case, when patients and studies have not been carefully selected, anomalous data might arise. In the scientific literature, many studies have dealt with the issue of elaborating local, regional and national DRLs, but few have explored the causes of the appearance of anomalous data in patient radiation dose distribution [16].

The study of outliers might be of relevance, as it can provide useful information on bad practice and correction possibilities. An experimental observation is statistically considered as an outlier when it lies at an abnormal distance from other values in a random sample of the population [17].

Several statistical methods have been described to mark observations as outliers, with the boxplot method proposed by Tukey the most widely used [18], due to its relative simplicity. Boxplot analysis provides information on the location, spread, skewness and tails of the data. As previously shown in other studies, CT doses are right skewed distributions [19], and in these cases the boxplot method marks too many points as outliers [20]. Vandervieren [21] proposed a generalization of the boxplot analysis that includes a robust measure of skewness, the medcouple parameter, in the determination of the whiskers of the boxplot. To our knowledge, this method has not been used for optimizing CT protocols.

In this work, it is presented a methodology adopted to access dose metrics outliers, as well as their main contributing causes.

\section{Material and methods}

\subsection{Data collection}

The study was approved by the Ethics Committee for Clinical Research, that accepted to waive the requirement to obtain the patient informed consent.

The automatic patient dose registry DoseWatch (DW, General Electric. Milwaukee. USA) used in this investigation receives information from all the modalities available at the hospital where the study was conducted. For this study, the focus was set on one of the most frequently used CT protocols, non-contrast Adult Head Routine Helical, used in a Siemens Somatom Definition AS + CT, with 128 slices and tube current modulation (CareDose4D), and automatic kilovoltage selection (CarekV). The predetermined Adult Head Routine protocol parameters are: single serie, $32 \times 1.2 \mathrm{~mm}$ collimation $5 \mathrm{~mm}$ image spacing, 0.55 pitch, H31S kernel, optional manual gantry tilt and 320 mAs reference quality, and kilovoltage automatically selected with CarekV. The dose calibration of the CT is periodically verified by medical physicists.

The studies performed throughout the year 2017 were taken as the reference distribution, and the following dose related parameters were selected for the analysis: CTDIvol, DLP, effective mAs and the study length. If deemed necessary, the whole set of technical parameters along with the scanogram of the examination is available in the patient's history stored in DW. Examination dose data were exported in excel format and afterward imported in Matlab@ (The Matworks Inc., Ma, USA) for detailed analysis. From this reference distribution, the thresholds used for outlier marking were obtained as shown in the following section.

\subsection{Outlier marking and analysis}

Outlier marking was carried out following the modified boxplot procedure of Vanderbiere [21], valid for skewed distributions. Tukey's thresholds for outlier marking were modified, introducing a robust measure of the distribution skewness, the medcouple (MC) parameter. This parameter varies between 1 and 1 , in such a way that the data distribution is right skewed when MC is positive, and conversely for left skewed ones MC is negative. Finally, for symmetrical distributions, the MC is zero. Medcouple parameter has a breaking point of $25 \%$, that is, it is a robust measure of skewness up to the presence of $25 \%$ of outliers in the distribution [21]. The medcouple parameter for a general continuous distribution $F$ of the variable $x$ is calculated according to the following expression:

$M C=\underset{x_{1}<m_{F}<x_{2}}{\operatorname{median}}\left(h\left(x_{1}, x_{2}\right)\right)$

where $\mathrm{x}_{1}$ and $\mathrm{x}_{2}$ sampled independently from $F, m_{F}$ is the median of the distribution $F$ and the kernel $h$ is calculated as

$h\left(x_{i}, x_{j}\right)=\frac{\left(x_{j}-m\right)-\left(m-x_{i}\right)}{x_{j}-x_{i}} \quad$ with $x_{i}<m<x_{j}$

A Matlab (The Matworks Inc., Ma, USA) routine was used to calculate the medcouple parameter of the reference distributions [22]. The outlier thresholds, that is, the limits beyond or below which an observation is marked as an outlier are defined as follows [21]

$M C \geq 0\left[Q_{1}-1.5 e^{-4 M C} I Q R ; Q_{3}+1.5 e^{3 M C} I Q R\right]$

$M C<0\left[Q_{1}-1.5 e^{-3 M C} I Q R ; Q_{3}+1.5 e^{4 M C} I Q R\right]$

with $Q_{1}$ and $Q_{3}$ first and third quartile, $I Q R$ the interquartile range and MC the medcouple of the reference distribution for the selected index (CTDIvol, DLP, mAs or study length). As can easily be seen, the classic boxplot thresholds are obtained when MC is equal to zero. If an observation falls below the lower threshold or above the upper threshold, then it is marked as lower-outlier or upper-outlier, respectively.

A certified medical physicist reviews the examinations marked as outliers and performs a preliminary analysis in order to identify the most probable causes. Subsequently, these cases are discussed within the framework of the dose committee in order to make a final report, taking into account all the possible contributing factors, both technical and patient related.

\subsection{Distribution comparison}

A monthly data export from DW was carried out. The monthly data of the dose indexes, considered as a sample from a more general population distribution, is tested against the reference distribution, via the non-parametric test for independent samples of Wilcoxon [23]. If the significance is higher than 0.05 , then a null hypothesis cannot be rejected, and there exist no significant differences between both distributions. On the contrary, for a significance lower than 0.05 the null hypothesis is accepted and thus, the monthly sample does not correspond to the reference distribution. This implies that the median dose (chosen as the local dose reference level) has significantly varied, either increasing or decreasing. In this case, further analysis should be undertaken to justify this dose variation.

\subsection{Cause-and-effect diagram}

In order to illustrate the relationship between the many contributing factors to the appearance of the effect (outlier), a Cause-and-Effect Diagram (Ishikawa diagram) is produced [24]. This type of diagram is useful in helping us to sort out the causes of the appearance of outliers and organize their mutual relationship. The analysis of the contributing causes was discussed in a committee composed by of medical physicists, radiologists, radiographers and organization representatives, called the dose committee. This committee is also responsible for the analysis of the individual outliers. 

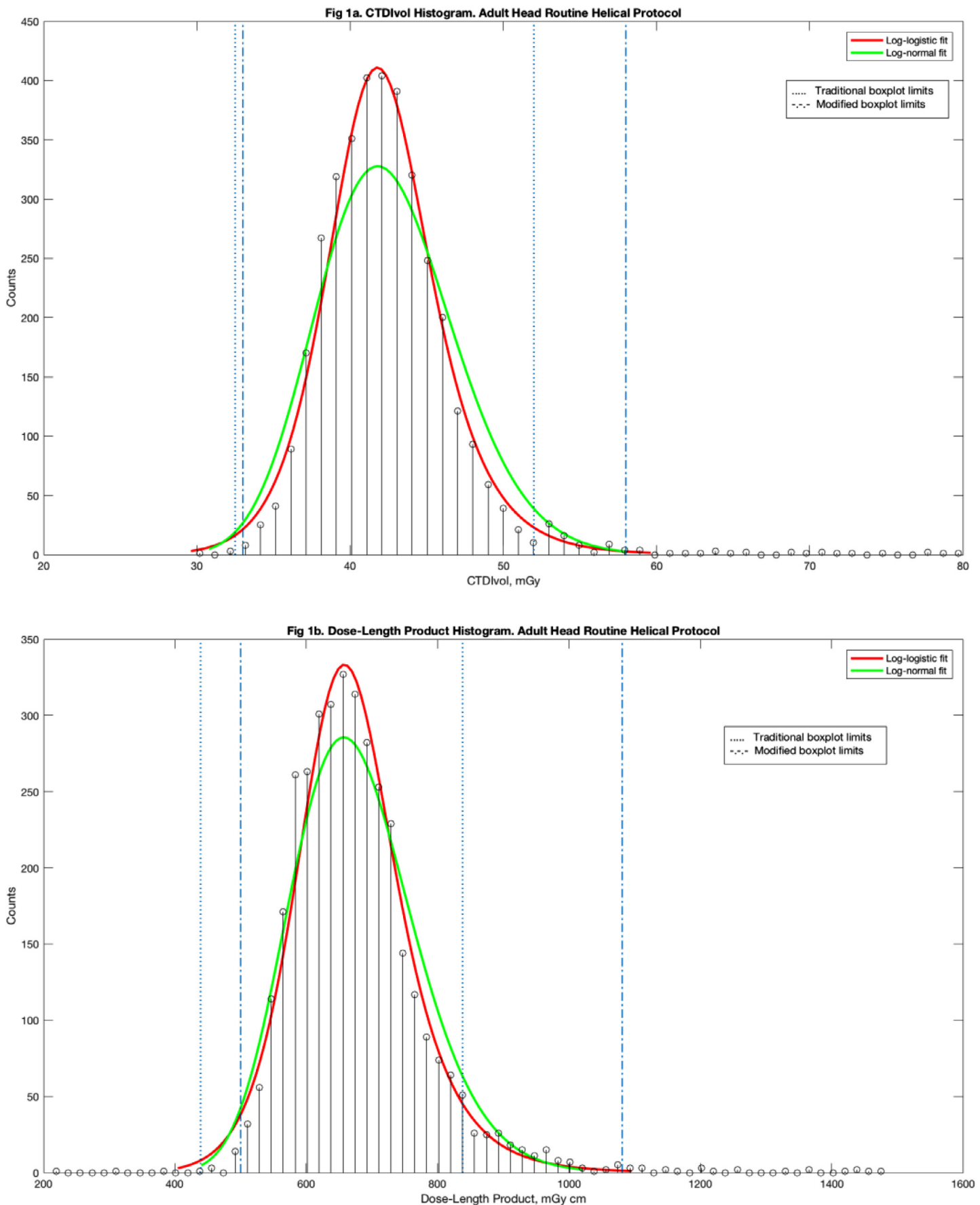

Fig. 1. Head Protocol Histogram of (a) CTDIvol and (b) DLP for the reference distribution. Both log-logistic and log-normal fits are also shown, and also the threshold for the traditional (.....) and modified (....-) boxplot methods. 


\section{Results}

\subsection{Reference distribution}

Throughout the reference period, 3690 Head Routine Helicoidal examinations were recorded. In Fig. 1, both the CTIvol and DLP histograms are shown. These distributions are the reference distributions against which the subsequent monthly samples were tested. From these distributions, the reference CTDIvol and DLP were $43 \mathrm{mGy}$ and $664 \mathrm{mGycm}$, respectively. These values are between 15\% and $45 \%$ lower than the DRLs found in the rest of European countries, which ranged from 50 to $79 \mathrm{mGy}$ for CTDIvol and 760 to $1300 \mathrm{mGy} \mathrm{cm}$ for DLP, and pointing out that Spain did not provide DRLs for CT examinations [25].

Both CTDIvol (Fig. 1a) and DLP (Fig. 1b) distributions have a medcouple parameter different from zero, 0.05 and 0.11 respectively, thus indicating the presence of a certain degree of skewness. Accordingly, the mAs and study-length distributions have a medcouple parameter of 0.03 and 0.20 . In all two of the histograms, log-logistic along with log-normal fits, performed with Matlab, are shown. It is interesting to note that log-logistic function fits better than log-normal one (loglikelihood 10191 vs 10342).

In Table 1, the main statistics used for the calculation of the outlier thresholds are presented. Studies with CTDIvol or DLP equal to zero, coming from anomalous records, were removed from the reference distribution before data analysis. After that filtering, the total percentage of outliers in the CTDIvol reference distribution were $1.5 \%$, where $0.5 \%$ corresponds to lower-outliers and $1.0 \%$ to upper-outliers, and in the DLP reference distribution, they were $2 \%, 0.7 \%$ lower-outliers and $1.3 \%$ upper-outliers. Therefore, the value of the statistics used for the outlier-threshold calculations were not affected by this low number of outliers, because of their low sensitivity to the presence of outliers.

\subsection{Outlier analysis}

The total number of outliers marked in the 4-month period of time analyzed was 68 for CTDIvol, for a total number of 1251 recorded studies, which means an average outlier monthly rate of $5 \%$. This figure is higher than that obtained for the reference distribution $(1.5 \%)$ because the monthly data had not previously been filtered, as the reference distribution had, and thus incorrectly registered studies were marked as outliers in the monthly analysis. The rationale behind not filtering the monthly data is to identify all the possible outliers and find their possible causes, while producing the reference distribution it is of main concern to have a distribution as much outlier free as possible.

The main causes of the appearance of CTDIvol upper-outliers were classified into 3 groups:

- Inadequate selection of the examination protocol (Fig. 2) in 65\% (44 out of 68) of the upper-outliers. Although the selected Head protocol is intended to be used for the head region, the examination was

Table 1

Statistics and outlier-thresholds for the reference distribution of the Head Routine Helicoidal protocol.

\begin{tabular}{cllllll}
\hline Parameter & $\begin{array}{l}\text { First } \\
\text { quartile } \\
\text { (Q1) }\end{array}$ & $\begin{array}{l}\text { Second } \\
\text { quartile } \\
\text { (Q2) }\end{array}$ & $\begin{array}{l}\text { Third } \\
\text { quartile } \\
\text { (Q3) }\end{array}$ & Medcouple & $\begin{array}{l}\text { Lower } \\
\text { outlier } \\
\text { threshold }\end{array}$ & $\begin{array}{l}\text { Upper } \\
\text { outlier } \\
\text { threshold }\end{array}$ \\
\hline $\begin{array}{c}\text { CTDIvol, } \\
\text { mGy }\end{array}$ & 40 & 42 & 45 & 0.050 & 33 & 58 \\
$\begin{array}{c}\text { DLP, mGy } \\
\text { cm }\end{array}$ & 610 & 664 & 724 & 0.111 & 500 & 1081 \\
mAs & & & & & & \\
$\begin{array}{c}\text { Study } \\
\text { lengt }\end{array}$ & 150 & 265 & 281 & 0.032 & 210 & 354 \\
h, cm & & 155 & 165 & 0.200 & 140 & 226 \\
& & & & & \\
\hline
\end{tabular}

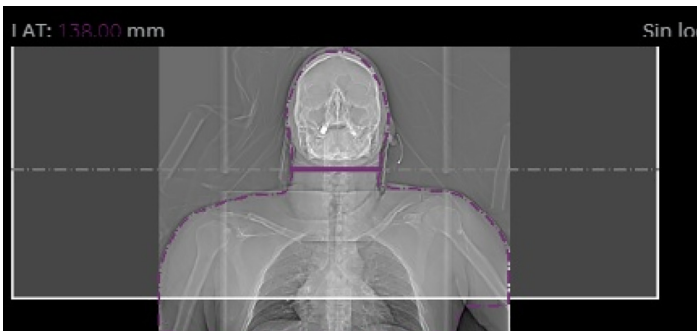

Fig. 2. Inadequate selection of the examination protocol example.

extended down to the neck and upper thorax due to a justified diagnostic reason. The Head protocol has both the tube current modulation and kilovoltage selection activated, thus, based on the scanogram, the CT selects a higher kilovoltage, $140 \mathrm{kV}$, versus the normal $100 \mathrm{kV}$ for the head region. Furthermore, the Head protocol has a higher quality reference in mAs than the neck-thorax protocol, thus resulting in even higher doses. These cases were marked as outliers for CTDIvol (due to an automatic increase of kilovoltage), DLP and study-length.

- Arms or objects in the field-of-view (Fig. 3 ) in $20 \%$ (14 out of 68) of the upper-outliers. The increased attenuation produced by arms or the presence of non-radiotransparent objects in the scanogram causes the system to increase the mAs to reach the reference quality for this protocol. These cases are upper outliers for CTDIvol and mAs.

- Abnormal scanning region diameter (Fig. 4) in 15\% (10 out of 68 ) of the upper-outliers. An erroneous positioning or anomalous anatomy (patients with shorter necks), lead to a higher mAs and hence an increase in CTDIvol. These cases are upper outliers for CTDIvol and mAs.

Lower-outliers of CTDIvol occur, in $90 \%$ of the cases, by the addition of new series which scan other parts of the body. When the patient examination is finished, the CT sends the study to DW, and it verifies that all the series coming from this study correspond to the head region, since the selected protocol was Head. But the phantom used for CTDIvol calculation for the head region is $16 \mathrm{~cm}$, versus $32 \mathrm{~cm}$ for the rest of the body, hence resulting in a much lower dose. Because DW does not take this difference into account, the series from regions other than the head, included in the Head protocol will be marked as lower-outliers for CTDIvol. In contrast, in these series, the study-length is marked as upper-outlier, because other parts of the body are usually longer than the head. This type of outlier might be avoided by either selecting a new protocol for each series, which is inefficient, or by making the dose registry system able to identify individual series and associate them to the correct protocol, which nowadays, DW is unable to do.

\subsection{Ishikawa diagram}

The root-and-cause analysis of the appearance of outliers produced 4 main groups: professionals, equipment, hospital organization and patient related (Fig. 5).

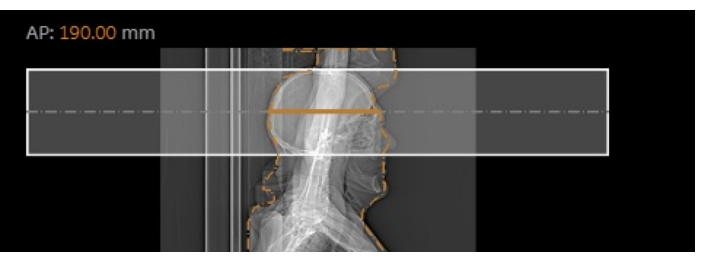

Fig. 3. Arms in the field-of-view example. 


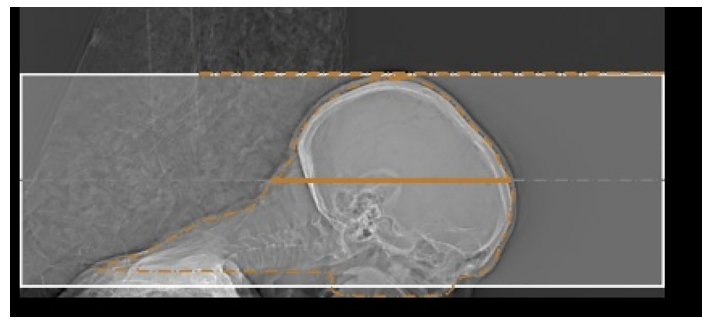

Fig. 4. Abnormal scanning region diameter example.

- Professionals. The increasing complexity of the CT technology, and especially the automatic selection of the kilovoltage and the tube current modulation, makes CT use more cumbersome than conventional radiographic X-ray systems. Hence, radiographers require specific training of the CT technology used in their work (i.e. a steep learning curve), as well as additional information on the use of the CT in cases far outside the standard ones, for example, patients with immobilizers that might significantly alter image quality. Another specific cause is human error, such as wrong protocol selection, coming from distractions during patient handling.

- Equipment. Three different systems might also be responsible for outliers: the CT, the contrast injector and the automatic registry system. Although the CT undergoes quality control by the medical physics department and maintenance by the service engineer, calibration drift might go unnoticed until an ionometric measure is done. Also, problems with the contrast injector might cause examination interruptions or repetitions. And finally, the incorrect classification of the series by the automatic registry system could cause outliers to be marked incorrectly.

- Hospital Organization. The lack of continuous training to ensure that the radiographer in charge of the CT has the necessary skills, substitutions, and staff rotation are among the attributable causes to hospital organization. An inappropriate working environment, or bad design inside the radiology department, are also sources of distraction.

- Patient related. A high Body Mass Index is the main cause of outliers attributable to patients, although this cause plays little role in the head region. However, inadequate positioning of the patient, as shown in Fig. 4, might considerably increase the diameter in the scanning region, and thus produce mAs increase. Care must be taken when metallic elements or high-density immobilizers are inside the scanning region, because this might increase the dose. Non-cooperative patients lead to series repetition or interruption.

\section{Discussion}

CT protocol optimization is a balance between image quality and patient dose. Most of the CT manufacturers have developed tools, such as tube current modulation or iterative reconstruction, to minimize the radiation dose, maintaining or improving the diagnostic quality of the images. The DRL methodology helps us to compare CT performance among different manufactures, protocols or institutions. DRLs cannot be applied to individual patients, but they are measures of the standard radiation dose delivered for a selected protocol. There is no clear indication how to continue the optimization process, even if it is advisable, when a CT protocol is below the DRL.

It is well known that the optimal CT radiation dose varies with patient size. Kanal et al [26] have developed national DRLs in USA as a function of patient size for the most 10 common CT adult examinations, in order to compare and optimize more effectively patient doses. Also, the clinical indication of the CT examination might significantly modify the required dose to achieve the appropriate image quality. In this sense, an European project (EUCLID) is underway to propose the establishment of DRLs based in clinical indications instead of anatomical locations [27]. They have found, among the scarce articles using this methodology, that a precise description of the clinical indication should be made in order to minimize any variation related to the meaning of the clinical indication during the survey. In fact, the protocol analyzed in this study, Adult Head Routine, is mainly used for patients with headache and/or neurologic deficit, and less commonly for head trauma.

\section{Cause and Effect Diagram}

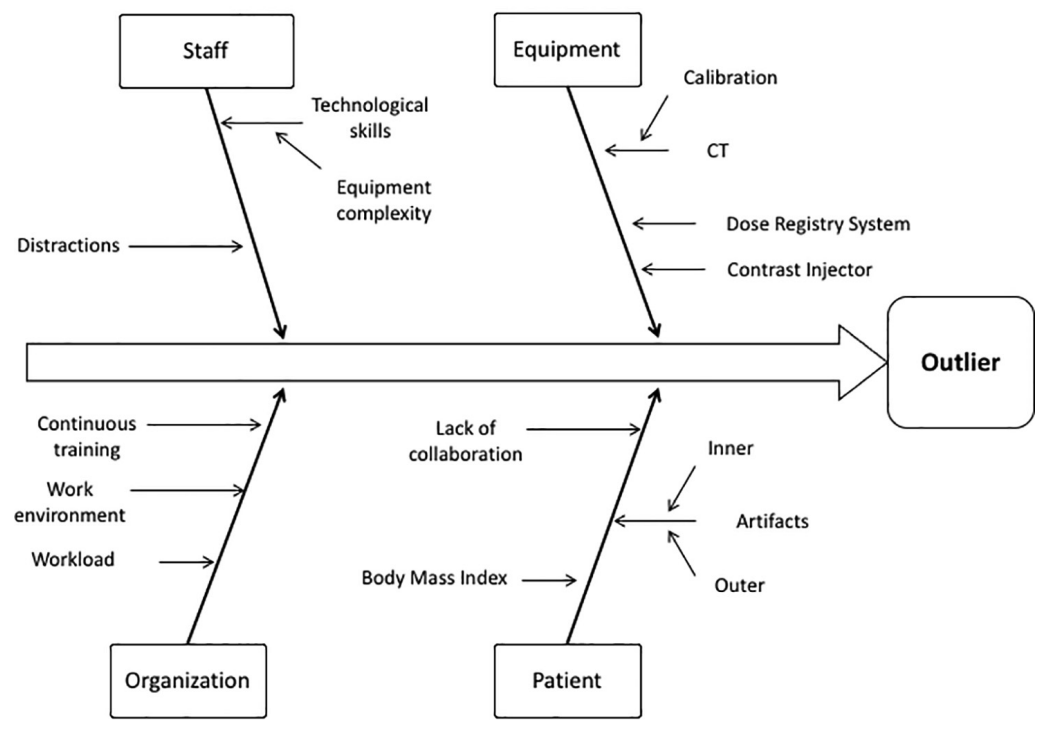

Fig. 5. Outliers Cause-and-Effect diagram. 
The presence of outliers in the patient dose distributions does not significantly alter the local reference dose, either because standard patients have been selected or because of their relatively low number. Thus, outliers usually go unnoticed, or the user pays little attention to them, although they might trigger alerts of high or low doses. Hence, we consider that the analysis of outliers might be a step further in the optimization process. It deals with individual cases, tries to find the root-cause, and enables the proposal of recommendations. So, while the DRL methodology is intended for standard patients, outlier analysis deals with nonstandard cases. Therefore, outlier analysis could be implemented once the DRL is fulfilled.

The problem arises when choosing the limits beyond or below which an observation is considered as an outlier. For instance, the International Commission on Radiological Protection (ICRP) recommends excluding the highest and the lowest $5 \%$ tails of the distribution [15], Chen et al [16] used the 1st and 99th percentiles to categorize outliers as low and high, respectively, Parakh et al [28] set the outlier threshold at $5 \mathrm{mGy}$ above their national DRL, emphasizing the lack of guidelines, and Dosewatch uses twice the median by default.

In this work, we have proposed a systematic way to mark data as outlier, taking into account the skewness of the distribution for each specific protocol, through the modified boxplot method. If we use the classic boxplot method, the number of outliers increases around 15\% for CTDIvol and $30 \%$ for DLP in relation to our proposal, thus generating a higher workload in the individual analysis process. Besides, it must be considered that outliers are not properly marked when the distribution is not symmetrical. As can be seen in Fig. 1a and b, where the thresholds of both the traditional and modified box-plot methods are shown, the main difference between them is found at the upper part of the distribution due to its skewness.

As for the CTDIvol upper-outliers, $100 \%$ had identifiable causes, mainly due to either incorrect use of the tube current modulation or a non-optimal selection of the examination protocol. Regarding the lower-outliers, $90 \%$ of the cases were due to the adding of series corresponding to other parts of the body, such as the thorax, abdomen or pelvis, and as for the remaining $10 \%$, the causes were classified as unknown.

Most centers rely on the judgment of the radiographer who performed the radiological examination to carry out the alert justification process. This procedure has at least two drawbacks: i) the radiographer seldom has the technological expertise to select among the multiple causes that might have contributed to the alert; ii) it is very difficult to have a radiographer admit to bad practice. The cases of both Figs. 2 and 3 were justified by the radiographer as "Study extension", and the case of Fig. 4 as "Unknown cause", but the correct causes were either incorrect patient positioning or wrong protocol selection. Thus, we propose that the justification process should be carried out in the framework of a multidisciplinary dose committee, where medical physicists, radiologists, radiographers and hospital managers discuss the most relevant outliers, and make recommendations to improve the practice. In this way, the justification process is a matter for everyone involved in the quality of the radiological process. This is well reflected in the Cause-and-Effect diagram, where the cause of outlier appearance is multifactorial, as has been thoroughly discussed in the results section. The proposed diagram is not exclusive for the CT and protocol analyzed in this study, but might also be applicable to any other protocol or CT machine.

The DRL methodology involves periodic audits of patient doses. The question then arises as to whether the median has significantly changed throughout time, or it is just a statistical fluctuation. We use the nonparametric Wilcoxon test to find out whether the monthly sample belongs to reference distribution or relevant changes have occurred in the CT or the protocol. This statistical test helps the user to decide whether the median variation is important, and then, whether further investigation is necessary, or the variation should be considered to be due to random fluctuations because of the finite size of the sample. In fact, during the monthly analysis, the Wilcoxon test indicated a significant variation of the CTDIvol in one month. While the median variation was $2 \%$ with respect to the reference value, this month had an important increase in the number of lower-outliers (more than $10 \%$ ), caused by incorrect protocol selection by a new radiographer. After removing these outliers from the distribution, because their causes were properly identified, the median dose variation decreased to $1.2 \%$ and the Wilcoxon test was not significant. Thus, we accepted that the dose did not change.

The automatic registry systems provide the user with valuable information about radiological examinations in almost real-time. But the analysis of the general performance of a CT or the search for outliers and their causes still depends on a professional or group of professionals. Currently, this process is carried out by exporting data to other analysis software such as Excel or Matlab. So, the problem now has changed from storing a huge amount of data to converting them into valuable knowledge, using more effective and efficient methods [29]. Hence, it would be desirable to have specific tools based on artificial intelligence applied to Big Data analysis in the search for optimization opportunities, marking and proper analysis of outliers, etc.

There are some limitations in this study. The outliers' analysis was carried out in a single CT and examination protocol, so it only considers one anatomical region. Thus, the causes found might not be thorough, as they might depend on the CT technology, radiographers' and radiologists' skills, clinical indications, etc. So, each center should address its own analysis by a dose committee, in order to implement corrective actions to optimize the practice. Future work will include expanding the outlier analysis methodology to include other anatomical regions, thorax, abdomen and pelvis, where other causes should, logically, appear, stressing the importance of a profound knowledge of X-ray technology by the staff involved in the radiological process.

\section{Conclusions}

Marking and analysis of outliers play an important role in the process of radiological protocol optimization, in a complimentary way to the DRL methodology. The specific shape of the dose index distribution must be taken into account to avoid incorrect outliers marking. The cause-and effect analysis of radiological examinations, both for high and low doses of a single protocol, by a multidisciplinary committee, helps to identify non-optimal use of the CT technology, and provides valuable insights to enable the further improvement of patients' safety.

\section{Acknowledgements}

This work has been supported by the project AIM, ref. TEC201676465-C2-1-R (AEI/FEDER, UE).

\section{References}

[1] Smith Bindman R, Miglioretti DL, Johnson E, Choonsik L, et al. Use of diagnostic imaging studies and associated radiation exposure for patients enrolled in large imaging studies and associated radiation exposure for patients enro
integrated healthcare systems, 1996 2010. JAMA 2012;307:2400 9 .

[2] OECD, Computed tomography (CT) exams (indicator); 2018. doi: 10.1787/ 3c994537 en. [Accessed 03 September 2018].

[3] Oatway WB, Jones AL, Holmes S, Watson S, Cabianca T. Ionising Radiation Exposure of the UK Population; 2010. Review. https://www. phe protectionservices. org.uk/cms/assets/gfx/content/resource_3595csc0e8517b1f.pdf/ [Accessed 13 June 2018]

[4] Berrington de Gonzalez A, Mahesh M, Kim KP, Bhargavan M, Lewis R, Mettler F, et al. Projected cancer risks from computed tomographic scans performed in the United States in 2007. Arch Intern Med 2009;169:2071 7.

[5] Triantopoulou S, Tsapaki V. Does clinical indication play a role in CT radiation dose in pediatric patients? Phys Med 2017;41:53 7.

[6] ICRP. Managing patient dose in digital radiology. ICRP Publication 93. Ann ICRP 2004;34(1).

[7] Council directive 2013/59/EURATOM of 5 December 2013, laying down the basic safety standards for protection against the dangers arising from exposure. https:// ec.europa.eu/energy/sites/ener/files/documents/CELEX 32013L0059 EN TXT.pdf [Accessed 24 June 2018]. 
[8] Nicol RM, Wayte SC, Bridges AJ, Koller CJ. Experiences of using a comercial dose management system (GE Dose Watch) for CT examinations. Br J Radiol 2016;89:20150617.

[9] MacGregor K, Li I, Dowdell T, Gray BG. Identifying institutional diagnostic re ference levels for CT with Radiation Dose Index Monitoring software. Radiology 2015;276:507 17.

[10] Boos J, Meineke A, Rubbert C, Heusch P, Lanzman RS, Aissa J, et al. Cloud based CT dose monitoring using the DICOM structured report: fully automated analysis in regard to national diagnostic reference levels. Fortschr Röntgenstr 2016;188:288 94.

[11] ICRP Publication 105. Radiation protection in medicine. Ann ICRP 2007;37(6).

12] Ghetti C, Ortenzia O, Palleri F, Sireus M. Definition of local diagnostic reference levels in radiology department using dose tracking software. Radiat Prot Dosimetry 2017;175:38 45.

[13] Treier R, Aroua A, Verdun FR, Samar E, Stuessi A, Trueb PR. Patient doses in CT xaminations in Switzerland: implementation of national diagnostic reference le vels. Radiat Prot Dosimetry 2010;142:244 54.

[14] McWilliams Nina, House Emerald, Donoghue Matthew, Tuohy Brendan. Determining diagnostic reference levels (DRLs) for radiography and fluorsocopy procedures in a University Based Teaching Hospital. Phys Med 2018;52:176 7.

[15] Vañó E, Miller DL, Martin CJ, Rehani MM, Kang K, Rosenstein M, et al. Publication 135: diagnostic reference levels in medical imaging. Ann ICRP 2017;46(1).

[16] Chen YA, MacGregor K, Li I, Concepcion L, Parameshvara D, Dowdell T, et al, Tracking and resolving CT dose metric outliers using root cause analysis. J Am Coll Radiol 2016;13:680 7.

[17] NIST/SEMATECH e Handbook of Statistical Methods, https://www.itl.nist.gov/ div898/handbook/. [Accessed 12 June 2018].

[18] Tukey JW. Exploratory data analysis. Reading. MA: Addison Wesley; 1977.

[19] Guidance National Diagnostic Reference Levels. https://www.gov.uk/government/ publications/diagnostic radiology national diagnostic reference levels ndrls/ national diagnostic reference levels ndrls. [Accessed 19 June 2018].

[20] Hoaglin DC, Mostseller F, Tukey JW. Understanding robust and exploratory data analysis. New York: Wiley; 1983.

[21] Vandervieren E, Huber M. And adjusted boxplot for skewed distributions. COMPSTAT 2004 Symposium. Proceedings in Computational Statistics. 2004. Prague.

[22] https://es.mathworks.com/matlabcentral/fileexchange/28501 tests to identify outliers in data series?focused 51601858tab function/. [Accessed 24 July 2018]

[23] Martin A, Luna JD. Bioestadística. Ed Norma Capel 2004.

[24] Ishikawa K. Guide to quality control. Asian Productivity Organization; 1976.

[25] European Commission. Directorate General for Energy. Diagnostic Reference Levels in thirty six European countries. Radiation Protection 180 2014. https://ec.europa. eu/energy/sites/ener/files/documents/RP180\%20part2.pdf/ [Accessed 24 Jun 2018].

[26] Kanal KM, Butler PF, Sengupta D, Bhargavan Chatfield M, Coombs LP, Morin DLUS. Diagnostic reference levels and achievable doses for 10 adult CT examinations. Radiology 2017;284:120 33

[27] Damilakis J, Frija G, Hierath M, Jaschke W, Mayerhofer Sebera U, Paulo G, et al. European Study on Clinical Diagnostic Reference Levels for X ray Medical Imaging. http://www.eurosafeimaging.org/wp/wp content/uploads/2017/09/D2.1_Report and review on existing clinical DRLs final published on website.pdf/ [Accessed 7 September 2018].

[28] Parakh A, Kortesniemi M, Schindera ST. CT Radiation dose management: a com prehensive optimization process for improving patient safety. Radiology 2016;280:663 73.

[29] Kersting K, Meyer U. From big data to big artificial intelligence? Künstl Intell 2018:32:3 8 . 
4.4. Artículo 4: Ionizing Radiation Measurement Solution in a Hospital Environment 
Article

\title{
Ionizing Radiation Measurement Solution in a Hospital Environment
}

\author{
Antonio-Javier Garcia-Sanchez ${ }^{1, *}$, Enrique Angel Garcia Angosto ${ }^{2}$, \\ Pedro Antonio Moreno Riquelme ${ }^{1}$, Alfredo Serna Berna ${ }^{3}$ and David Ramos-Amores ${ }^{3}$ \\ 1 Department of Information and Communication Technologies, Universidad Politécnica de \\ Cartagena (UPCT), Campus Muralla del Mar, E-30202 Cartagena, Spain; pamr0@alu.upct.es \\ 2 Services, General Electric Healthcare España S.L.U., 28023 Madrid, Spain; enrique.garciaangosto@ge.com \\ 3 Department of Radiophysics, Hospital General Universitario Santa Lucía, C/Mezquita, s/n, Paraje Los \\ Arcos, E-30202 Cartagena, Spain; alfredo.serna@carm.es (A.S.B.); david.ramos@carm.es (D.R.-A.) \\ * Correspondence: antoniojavier.garcia@upct.es; Tel.: +34-968-326-538
}

Received: 26 December 2017; Accepted: 4 February 2018; Published: 8 February 2018

\begin{abstract}
Ionizing radiation is one of the main risks affecting healthcare workers and patients worldwide. Special attention has to be paid to medical staff in the vicinity of radiological equipment or patients undergoing radioisotope procedures. To measure radiation values, traditional area meters are strategically placed in hospitals and personal dosimeters are worn by workers. However, important drawbacks inherent to these systems in terms of cost, detection precision, real time data processing, flexibility, and so on, have been detected and carefully detailed. To overcome these inconveniences, a low cost, open-source, portable radiation measurement system is proposed. The goal is to deploy devices integrating a commercial Geiger-Muller (GM) detector to capture radiation doses in real time and to wirelessly dispatch them to a remote database where the radiation values are stored. Medical staff will be able to check the accumulated doses first hand, as well as other statistics related to radiation by means of a smartphone application. Finally, the device is certified by an accredited calibration center, to later validate the entire system in a hospital environment.
\end{abstract}

Keywords: gamma radiation; healthcare workers safety; dosimetry solution; verification; evaluation

\section{Introduction}

The exposure of healthcare workers to ionizing radiation is a relevant concern due to the health risks involved [1]. Governments and authorities are working to foster ionizing radiation safety. In this way, recent directives (e.g., Council Directive 2013/59/Euratom) [2] have set basic safety standards to protect the health of individuals from dose exposures. Under these directives, healthcare workers in charge of radiology exposed to this type of radiation need to be monitored on a daily basis.

The most effective way of protecting medical staff who regularly work in controlled areas is the continuous measurement of the accumulated radiation level in their bodies. To this end, we have performed an exhaustive analysis of the current commercial radiation monitoring instruments, and divided them into two main groups: personal dosimeters and area survey meters. Personal dosimeters are small devices which healthcare workers wear on the body part most exposed to radiation. Thermo-luminescence based solutions are the most widely used technology where, after a period (usually a few weeks), the device is sent to a specialized laboratory to analyze the received doses. Therefore, the measurement is off-line, which restricts its usefulness. On the other hand, area dosimeters measure the radiation doses in real time, with most of them lacking Internet connections or database storage. These large devices are only placed in certain areas of the hospital (for instance, in the Nuclear Medicine department). 
To overcome these drawbacks, a system has been designed, developed, verified and checked as a hybrid solution, valid as both a personal dosimeter for specific zones and an area dose meter. The entire system is based on open-source technology, integrating commercial off-the-shelf (COTS) electronic components including Internet connections via 3G, Ethernet or WiFi. The system functionality is the following one: a device collects the doses employing a commercial GM tube and dispatches them to a remote database hosted in a server. It is responsible for storing all the information received for each healthcare worker, immediately calculating accumulated, average and deviation doses, and providing a highly flexible solution. Also, medical staff are aware of these values in real time, thanks to a smartphone application. This code, as well as the remaining software developed for this work, is available in [3].

The device was verified at the National Dosimetry Centre (CND) in Valencia, Spain under reference laboratory conditions. The complete solution was tested at the Sta. Lucia University Hospital, located in Cartagena (southeastern Spain), using two devices. The first one was placed in a corridor next to the PET department and the second one at the control area of the Computer Tomography (CT) area. The results were compared to calibrated electronic dosimeters, demonstrating the correct procedure carried out by the system's measurement.

The rest of this paper is organized as follows: Section 2 introduces the technological background related to this research, where dosimetry concepts and a commercial dosimeter classification are thoroughly described; Then, the following Section 3 presents our proposal detailing both its hardware and software architecture, thus, the benefits of the solution offered in respect to the remaining commercial dosimeters are also highlighted. Section 4 deals with the procedure for verifying the device in hospital environments; Section 5 validates our system at Sta. Lucia University Hospital; results are analyzed and discussed, and finally, Section 6 summarizes the main conclusions.

\section{Technological Background}

\subsection{Ionizing Radiation}

Ionizing radiation is that with enough energy to ionize matter, by removing electrons from their states joined to their corresponding atom. It may be produced by radioactive substances, which emit such radiation naturally, or by artificial generators such as X-ray generators and particle accelerators.

The ionizing radiation sources naturally occurring in the earth's surface can be classified as alpha, beta, gamma or X-ray particles. Their features are explained in the following paragraphs:

- Alpha particles $(\alpha)$ : They are usually generated in nuclear reactions or radioactive disintegration. Their capacity of penetration is low. They quickly lose their kinetic energy in the atmosphere, because they interact strongly with other molecules due to their great mass and electrical charge, generating a significant number of ions per centimeter of covered length. In general, they cannot pass through the thickness of multiple sheets of paper. However, if an alpha emitter enters the body it can be very harmful.

- $\quad$ Beta particles $(\beta)$ : They have greater penetration than alpha particles. They can be stopped by a few centimeters of wood or a thin sheet of metal. However, as with alpha particles, they can cause serious damage to the human body.

- Gamma particles $(\gamma)$ : Gamma radiation $(\gamma)$ is a type of electromagnetic radiation [4]. Gamma rays can cause serious damage to the nucleus of cells, so they are used to sterilize medical equipment and food. Gamma rays easily pass through the skin and other organic substances; therefore, they could cause serious damage to internal human organs. X-rays are included under this category. They are also photons, but with a lower penetration capacity than gamma rays.

\subsection{Recommended Criteria to Assign Dosimeters for Healthcare Workers}

- The Spanish Health Protection regulation against Ionizing Radiation (Royal Decree 783/2001 (BOE 26/07/2001) defines exposed healthcare workers as those who, due to the circumstances 
in which their work is carried out, are habitually/occasionally subject to the risk of exposure to ionizing radiation that may involve doses higher than the limits recommended for members of the public. Exposed healthcare workers are further classified into two categories, A and B:

1. Category A includes those who can receive an effective dose greater than $6 \mathrm{mSv}$ (miliSievert) per official year, or a dose greater than 3/10 of the equivalent dose limit for eye lenses (45 mSv/year), skin and limbs (150 mSv/year). In Category A, exposed workers must use a personal dosimeter.

2. Category B includes exposed workers who rarely receive effective doses in excess of $6 \mathrm{mSv}$ per official year, or 3/10 of the equivalent dose limit for eye lenses, skin and limbs. These workers are not necessarily required to wear personal dosimeters. It is sufficient for them to be controlled by a dosimetry monitoring system that guarantees that the doses received are compatible with their level B classification.

3. Non-exposed workers, such as members of the public health system, do not require any dosimetry control.

Table 1 summarizes the effective dose levels together with the equivalent doses in eye lenses, skin and limbs used in this staff classification.

Table 1. Dose level ranged by exposition category.

\begin{tabular}{cccc}
\hline Healthcare Professional Category & Effective Dose & Eye Lense Dose & Extremity Dose \\
\hline Exposed worker A classification & $>6 \mathrm{mSv} /$ year & $>45 \mathrm{mSv} /$ year & $>150 \mathrm{mSv} /$ year \\
Exposed worker B classification & $<6 \mathrm{mSv} /$ year & $<45 \mathrm{mSv} /$ year & $<150 \mathrm{mSv} /$ year \\
Non-exposed workers & $<1 \mathrm{mSv} /$ year & $<15 \mathrm{mSv} /$ year & $<50 \mathrm{mSv} /$ year \\
\hline
\end{tabular}

A minimum number of people working under ionizing radiation conditions in the healthcare environment are classified as Category A exposed workers, and would be required to be controlled by individual dosimetry. These workers are the following:

- Those who have to stay close to the radiation beam in interventional radiology and hemodynamics.

- Healthcare workers preparing and administering radioactive doses in nuclear medicine.

- Healthcare workers who are involved in the preparation of treatment and care of patients in radioactive metabolic therapy.

- Healthcare workers performing these functions in brachytherapy.

Table 2 shows the percentages of workers with accumulated annual doses exceeding the annual dose limit for members of the public ( $1 \mathrm{mSv}$ per year, established by the General Radiation Protection Manual, CSN/SEPR/SEFM Forum, June 2003), classified by category and work type.

Table 2. Percentage of healthcare workers exceeding the annual dose limit according to their job type.

\begin{tabular}{ccccc}
\hline Job Type & Doctor & Medical Assistant & Operator & Other \\
\hline Outpatient clinic Radiology & $0.0 \%$ & $0.40 \%$ & $0.0 \%$ & $0.0 \%$ \\
Hospital Radiology & $2.7 \%$ & $1.40 \%$ & $0.5 \%$ & $0.4 \%$ \\
Vascular Radiology & $24.1 \%$ & $5.90 \%$ & $2.9 \%$ & $1.5 \%$ \\
Radiotherapy & $0.1 \%$ & $2.60 \%$ & $0.4 \%$ & $0.7 \%$ \\
Nuclear Medicine & $1.7 \%$ & $50.70 \%$ & $36.6 \%$ & $13.0 \%$ \\
Interventional & $2.2 \%$ & $0.40 \%$ & $0.0 \%$ & $0.1 \%$ \\
Others & $0.6 \%$ & $0.30 \%$ & $0.0 \%$ & $0.0 \%$ \\
\hline
\end{tabular}




\subsection{Dosimetry Classification}

\subsubsection{Personal Dosimetry}

Dosimetry estimates the doses received by a given person. Depending on the body area you wish to estimate, personal dosimetry is classified into:

1. Dosimetry of the whole organism: It is implemented by a lapel dosimeter, which must be placed in a position that is representative of the most exposed part of the body surface. In those cases where a lead apron is required, the dosimeter should be placed under the apron.

2. Dosimetry of the upper extremities: It is implemented by wearing wrist or ring dosimeters. Recommended only in those cases where the doses to the hands can be notably higher than those of the whole organism, due to their proximity to the radiation beam.

3. Abdomen dosimetry: It is implemented by lapel dosimeters. Only used on the abdomen of exposed pregnant workers. Where a lead apron is required, the dosimeter should be placed under the apron.

There are a lot of personal dosimeters on the market. The most common ones are described below:

- $\quad$ Thermo-luminescence dosimeter (TLD) [5].

It incorporates anodized aluminum foil with four thermo-luminescent detectors. These detectors are usually made of lithium fluoride activated with magnesium or calcium fluoride activated, in turn, with manganese.

The detectors store the energy received from ionizing radiation. In order to know the amount of radiation received by the dosimeter, it is necessary to heat it to a temperature of $300{ }^{\circ} \mathrm{C}$, thus releasing the stored energy in the form of light. The amount of light emitted is proportional to the radiation dose received by each detector.

The lapel dosimeter is designed for the measurement of deep personal equivalent doses denoted as $\mathrm{Hp}(10)$ and superficial doses called $\mathrm{Hp}$ (0.07) [6], as well as for energy discrimination from incident radiation.

The main advantages are its low cost, easy handling, sensitivity, and that it does not depend only on environmental conditions. Furthermore, it is reusable: Once the dosimeter receives the radiation dose during a period of time, it can be employed again. However, its main drawback is related to that the radiation cannot be observed in real time, which negatively impacts on its applicability.

- $\quad$ Film dosimeter [7].

It contains a small piece of radiographic film, placed between two metal filters (usually aluminum or copper) inside a plastic casing, in order to protect the film from light exposure. Some film dosimeters have two emulsions, one for low doses and the other for high dose measurements. These two emulsions can be on separate film substrates or on either side of a single substrate.

When the film is irradiated, an image of the protective box is projected onto the film. In this way, the amount of radiation received is proportional to the optical density of the film being exposed, compared to the optical density of previously calibrated films.

The main advantage is its functionality. Film can provide information on the exposure conditions such as the direction of the incident radiation or suspected contamination. The main drawback is that the reading is estimated, not immediate, and not reusable. It also depends on external conditions, such as humidity.

- $\quad$ Radiophotoluminescent Glass Dosimeter (RPLGD) [8].

It consists of a housing that incorporates a radiophotoluminescent (RPL) glass in the center. The RPL crystal material is activated silver with crystallized phosphate glass $\left(\mathrm{P}_{2} \mathrm{O}_{5}\right)$. When this 
material is exposed to radiation, stable luminescent centers are created in the silver ions, denoted as $\mathrm{Ag}^{\circ}$ and $\mathrm{Ag}^{2+}$. These ions emit light when stimulated. To produce this stimulation, the crystal is irradiated with ultraviolet light, measuring the light emitted with a photo multiplier tube. So, the intensity of the light emitted will be proportional to the radiation dose received.

The main advantage is its reusability. In the reading procedure, the stored dose is not eliminated. Therefore, it allows us to accumulate the radiation dose in the very long term. In addition, it is not sensitive to ambient temperature, which favors the measurement precision. The main drawback is that it doesn't measure data in real time and it doesn't export data.

- $\quad$ OSL (Optically stimulated luminescence) dosimeter [9].

These dosimeters incorporate a sheet of carbon-activated aluminum oxide, located between filters, to obtain qualitative information on the conditions during exposure. To know the amount of radiation dose received, the aluminum oxide is stimulated at specific frequencies by means of a laser. In this way, the intensity of the light emitted will be proportional to the dose of radiation received.

As in previous cases, its main advantage is its reusability. It can be reused a few number of times without losing sensitivity. On the other hand, commercial devices lack remote connectivity and data storage.

- $\quad$ Electronic Personal dosimeter [10].

It uses electronic sensors and signal processing, and shows the radiation dose normally received in microSievert $(\mu \mathrm{Sv})$. This dosimeter either has a miniature Geiger-Müller tube or is equipped with silicone sensors.

The main advantage is that it can continuously display the accumulated dose on the screen, so it is often used as an alternative in emergency cases in which it is necessary to know a specific amount of radiation within a short period of time. Additionally, it can incorporate alarms if a previously programmed accumulated radiation dose is exceeded during a certain period of time. It works with batteries. The main drawbacks are the cost and the lack of connectivity.

\section{- $\quad$ Pen/pocket dosimeter [11].}

It is a small ionization chamber, cylindrical (approximately $2 \mathrm{~cm}^{3}$ ) in shape, filled with air and equipped with a central electrode. It is shaped like a ballpoint pen and contains an ionization chamber with a quartz fiber electrode that functions as an electroscope. By means of an optical arrangement, the response of the radiation action can be observed.

The main advantage of this equipment is that the reading of this dosimeter is straightforward and very easy to use. The main drawback is the fact that it has a poor range of use and low sensitivity compared to other dosimeter systems. It requires daily radiation monitoring and daily charging. Occasionally, it can even be discharged when hit. Therefore, for some years now, its use has been reduced significantly.

Finally, Table 3 summarizes the radiation ranges for each personal dosimeter type listed above.

Table 3. Radiation range for personal dosimeter.

\begin{tabular}{cc}
\hline Dosimeter & Range \\
\hline Film and TLD dosimeters & $100 \mu \mathrm{Sv}-10 \mathrm{~Sv}$ \\
OSL and RPL dosimeters & $10 \mu \mathrm{Sv}-10 \mathrm{~Sv}$ \\
Self-reading pocket dosimeters & $50 \mu \mathrm{Sv}-0.2 \mathrm{~Sv}$ \\
Electronic Personal dosimeter & $0.1 \mu \mathrm{Sv}-10 \mathrm{~Sv}$ \\
\hline
\end{tabular}




\subsubsection{Non-Personal Dosimetry}

Non-Personal Dosimeters are devices that estimate the received dose in a particular place [12]. They can be classified as:

1. Area dosimetry: It is performed by means of lapel dosimeters. It is reserved for the estimation of doses in places or areas where workers are exposed under category A.

2. Dosimetry of rotating workplaces: It is performed using lapel and/or wrist dosimeters. It is focused on estimating doses in those workplaces where an activity is occasionally performed, and category B workers could be exposed.

3. Research dosimetry: It is carried out using lapel and/or wrist dosimeters. It is requested by a Radiation Protection Service to measure doses in all those situations not covered in the previous cases.

The following paragraphs will describe the main types of area dosimeters used in hospital environments today. To this respect, they can be divided into two main groups: (i) gas detectors and (ii) solid-state detectors.

- Gas detectors

Gas detectors are based on the direct gathering of the ionization phenomenon caused by a particle when passing through a noble gas, enclosed between two electrodes subjected to a potential difference. This type of gas is used because the dose rate that can be monitored should be as high as possible. In this group, there are three main types of detectors: (1) ionization chambers; (2) proportional counters and (3) Geiger-Müller counters. Each one accomplishes specific functions, implying different shapes and sizes.

1. Ionization chamber [13]. It is the most straightforward gas detector, considered as a plane-parallel capacitor, in which the region between planes is completely filled with a gas, preferably with air. The electric field in this region prevents the recombination of the ions with electrons, which involves electrons moving towards the positive electrode, while positively charged ions move to the negative electrode. The applied voltage sets the velocity at which electrons and ions move to the chamber electrodes. For instance, for a typical voltage value of about $100 \mathrm{~V}$, ions move at speeds of $1 \mathrm{~m} / \mathrm{s}$. Under these conditions, ions take up to $0.01 \mathrm{~s}$ to get through a $1 \mathrm{~cm}$ thick chamber (note that electrons are more mobile than ions and they will move 1000 times faster). An inconvenience is that these temporal values are excessively long for the time dealt with in radiation detection (e.g., a Computer Tomography).

2. Proportional counter [14]. It consists of a metal case filled with a noble gas such as argon or xenon, with a very fine thread crossing the center. The wire (anode) is set at a high potential difference in relation to the box, so that an electric field constantly passes through the gas. The process is the following: when an ionizing particle, such as an electron, goes through the gas, it releases electrons from its atoms (it ionizes the atoms), leaving behind a positively charged ion and a free electron. The free electrons generated in the gas are accelerated to the anode and their amount is proportional to the initial energy of the particle or X-ray. Unlike simple ionization chambers, the potential difference used in proportional counters is much greater, so the electrons accelerated towards the anode have enough energy to produce secondary but proportional ionizations (hence the name of the device), causing an electronic "cascade". The electric current or voltage generated in the anode can then be measured and digitized and, as mentioned above, the voltage or charge is proportional to the energy of the particle or X-ray incident. To be able to observe individual pulses, we must increase the applied voltage (which means exceeding $1000 \mathrm{~V}$, its main inconvenience). To this respect, the largest electric field is capable of accelerating electrons so that they can generate secondary ionizations. Accelerated secondary electrons produce new ionizations, eventually creating an avalanche or cascade of ionizations. 
3. Geiger-Müller counter [15]: If the electric field increases further, the Geiger-Müller region is reached. In this case, secondary avalanches are generated anywhere in the tube, caused by photons emitted by atoms stimulated in the original avalanche. These photons move relatively far from the original avalanche location and, in a short time, the entire tube is involved in the process. Counters based on this principle are known as Geiger-Müller meters. Since the entire tube is involved in each initial avalanche, there is no information on the energy of the original radiation (all incident radiation produces identical output pulses valued around $1 \mathrm{~V}$ ). So, Geiger-Müller counters are employed as pulse counters. However, in these counters there is a serious problem. During their movement into the tube, ions can be accelerated, reaching the anode with enough energy to release electrons and starting the process again (due to the nature of the multiple avalanches). To overcome this inconvenience, a second type of gas, called quenching gas, is added. This gas is made up of complex organic molecules such as ethanol (while the primary gas is usually made up of simple molecules, such as argon). A typical mixture of gases will be: $90 \%$ argon and $10 \%$ ethanol. The molecular nature of this added gas prevents the appearance of continuous avalanches. Geiger-Müller sensors allow the obtaining of accurate radiation doses with a remarkably low cost, and its integration into any electronic system to manage the information and dispatch it to remote places is a straightforward process. These are the main reasons why the Geiger-Müller counter has been adopted as part of our proposal.

- $\quad$ Solid State Detectors

The solid state detector, also known as Semiconductor Radiation Detector, is a radiation detector in which a semiconducting material (silicon or germanium) constitutes the detecting medium. Solid detectors have higher densities that provide reasonable absorption probabilities for a normal detector size. Two types will be described: (1) scintillating counters and (2) semiconductor detectors:

1. Scintillator counters [16]. The scintillator counter works as follows:

- Incident radiation interacts with the atoms and molecules of the material, stimulating them.

- Stimulated states are de-energized by emitting visible (or nearly visible) fluorescent light.

- The light reaches a photosensitive surface by pulling out photoelectrons.

- The electrons accelerate and multiply in number to form an electrical pulse.

There is a wide variety of available scintillators and photomultiplier tubes, depending on the type of application. The properties to be considered in the selection of the material include the fraction of incident energy that appears as light, efficiency (the probability of radiation being absorbed), response time and energy resolution.

\section{Semiconductor detectors [17]}

Semiconductor solid materials (germanium and silicon) are alternatives to scintillators for building radiation detectors. When a type-p semiconducting material is in contact with a type-n semiconducting material, the electrons of the type-n semiconductor can diffuse through the junction in the type-p semiconductor and combine with the vacant ones. In the vicinity of the $p-n$ junction, the charge conductors are neutralised, creating a region called the depletion zone. The diffusion of electrons from the n-type region leaves behind ionized, fixed donor states, while in the p-type region there are fixed acceptor states charged negatively. Thus, an electric field is created, which ultimately makes diffusion phenomenon advances impossible. A typical p-n junction of a diode is formed.

If any radiation penetrates into the depletion zone and creates an electron-hole pair, the result is very similar to that of an ionization chamber. The electrons flow in one direction and the vacancies/holes in the other. The final number of collected electrons creates an electronic pulse whose amplitude is proportional to the energy of the radiation. 
Concerning the manufacturing of these detectors, it is possible to initiate them from a p-type semiconductor in which lithium atoms are diffused. The n-type layer created by producing detectors such as $\mathrm{Ge}(\mathrm{Li})$ or $\mathrm{Si}(\mathrm{Li})$ is in the order of $1 \mathrm{~mm}$ thick, which is easily penetrable by medium-energy gamma rays (the range of a photon of 100 kiloelectronvolt in Ge is about $4 \mathrm{~mm}$ and in Si about $2 \mathrm{~cm}$ ). However, in the case of charged particles the range is much smaller (e.g., for 1 megaelectronvolt electron the range is $1 \mathrm{~mm}$ in $\mathrm{Si}$ and Ge; for 5 megaelectronvolt alpha particles, the range is only $0.02 \mathrm{~mm}$ in both) and there is a $1 \mathrm{~mm}$ thick layer to prevent the particles from accessing the depletion zone.

The main advantages are that the time required to collect the load of large detectors is in the range of 10-100 ns, depending on the shape of the detector (flat or coaxial) and the point of entry of the radiation with respect to the electrodes. This time is less than that obtained in an ionization chamber, since here the path followed by the created loads is reduced by several orders of magnitude. Another clear advantage of these types of solid detectors is related to energy. Less energy is required to create an electron-hole pair $\left(\sim 3.6 \mathrm{eV} /\right.$ pair in $\mathrm{Si}$ at $\left.300^{\circ} \mathrm{K}\right)$, thus, excellent energy resolution is obtained. An inconvenience is the lack of connectivity in commercial devices.

\subsection{Discussion}

As for personal dosimetry, thermo-luminescent dosimeters are the most widely used in Spanish hospitals. However, as previously mentioned, their main drawback is the lack of real time measurements. Each personal dosimeter will be transferred at least once a month to a specialized center (in Spain, the National Dosimetry Centre-CND) which will heat it to up to $300{ }^{\circ} \mathrm{C}$. The amount of light thus emitted is proportional to the radiation dose received.

During this period of time, in which the CND estimates the level of radiation received by the dosimeter, health personnel will have another dosimeter made available to measure the radiation of the following month. So, a monthly radiation level is obtained and there is no possibility of knowing specific periods of time with higher doses during this time because the radiation dose is accumulated.

As for area dosimetry, most of the devices used in a hospital environment lack any connection to remote systems in order to receive the dose. Usually, the only way to get the data is to be in front of the dosimeter and to check the dose.

On the other hand, there is an important concern regarding data storage. These types of devices store the average radiation values in specific temporal periods. Data are released after each period to restrict data storage. To carry out a later evaluation of emitted radiation, it will not be possible to access radiation values outside of the current period.

In addition, if users want to store the data directly on a PC, it is necessary to have it in the same room as the area dosimeter, which in some cases, can be a complex or impractical task, for instance, in a hospital corridor or in a computer tomography room (cases of study proposed in this work).

In summary, the major drawbacks detected in the current instrumentation for ionizing radiation measurement are described in the following points:

1. Limited storage. There are devices that can store the radiation captured internally. However, due to the limited memory capacity of these devices, it is not possible to have a large amount of stored data.

2. Scarce Flexibility. Most devices do not allow the collection of data in any other way than that established by the manufacturer. In the particular case of personal thermo-luminescent dosimeters, where the stored data can be accessed, radiation collection must be stopped and be replaced by another device while accessing the data.

3. High cost. Those alternatives that have some storage capacity and offer results in accurate, real time radiation doses (especially for area dosimeters) have a clear impact on the cost. Therefore, these solutions are addressed to public entities or big, private companies.

4. Power supply. A large number of dosimeters described in this section are supplied by batteries. In the case of failing batteries, the received dose is not computed and a health risk could result. 
5. Manufacturer dependent. A priori, any modification of the device firmware to adapt it to new conditions of the application/environment is not possible.

\section{Proposal}

\subsection{General Overview}

The radiation measurement proposal is a step forward, which solves diverse problems presented by current radiation systems. Figure 1 shows the main system components where the entire system integrating wireless communications, database, mobile application and measurement device have been highlighted.

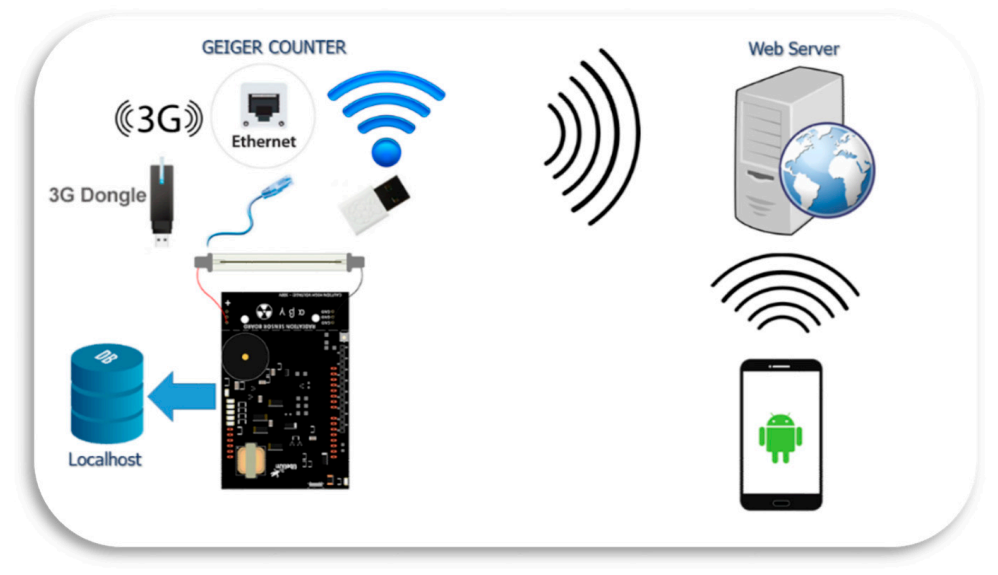

Figure 1. System components.

As a general approach, the radiation is measured with a commercial Geiger-Müller tube [18], receiving two values: (i) the effective dose-rate value $(\mu \mathrm{Sv} / \mathrm{h})$ and (ii) the counts per minute (CPM). These values are stored in two redundant databases: one hosted on a remote web server and the second in a database implemented in a Raspberry Pi [19] (localhost), which in addition, provides memory storage, processing and connectivity. Note that this commercial detector can be replaced by another; without thereby the system functionality lessen. Therefore, it is not an objective of this work to characterize and study this sensor, tackling these concerns in future works. For instance, it should be interesting to model the GM directivity, to later implement it in the Raspberry. Furthermore, in the case of using detectors such as the solid state ones (because the application requires it), environmental parameters (temperature, pressure, humidity, etc.) must be considered to adjust its operation. As in previous case, the detector adjustment will be developed in the corresponding software module of the Raspberry. Under these premises, to have of a COST-based system facilitates the design of specific solutions in accordance with application or service requirements.

The set of radiation measurement, capture, and storage procedure is performed in periods of one second, i.e., the sensor measures radiation doses and counts per minute (both values form the data) at one-second intervals and stores both values in the Raspberry Pi and web server. In this way, it provides a versatile solution for the storage problem that current systems are facing today.

The data uploading to the database of the web server is carried out through 3G, Ethernet or WiFi technology, which ensures flexibility and reliability in the face of any contingency in the transmission of information (e.g., falling $3 \mathrm{G}$ network, WiFi router failure, etc.). Furthermore, the user has access to a smartphone application, which is able to show information in real time, or statistics of radiation values computed in remote web server: Daily measurements, averages, deviations and so on. 
The user could access data through the web server, as well as being able to export them to other formats, for instance, a spreadsheet (e.g., Excel) to analyze the data in more detail. In addition, access to the data does not stop the operation of the device, which is the main drawback of some of the current systems.

The system could be used either as a personal dosimeter and/or as an area dose meter. Regarding area dosimeters, it is obvious, since its functioning is the same as Geiger counters. To use it as a personal dosimeter, healthcare staff have to $\log$ in and register in the smartphone application. So, for each registered user, the received radiation is stored in the corresponding databases, to later consult instantaneous, accumulated, mean radiation values of dose. In this regard, it provides a real-time solution in personal dosimetry, avoiding long waiting periods in order to know the received radiation data, as occurs in many of the current systems (e.g., thermo-luminescent dosimeters) which are connectable from any place through Internet access.

The Geiger-Müller detector is powered by the Raspberry Pi, so this device just has to be connected to the power supply, thus avoiding the energy limitations of other electronic dosimeters. Once connected to the power supply, the first step that the system performs is to connect to the remote database and start receiving radiation values.

Among all the aforementioned technologies, the system has a Geiger-Müller tube, therefore a Geiger counter. A sensor of this type usually triggers pulses, which is not an energy value, so it would not be useful for knowing the dose of radiation received by health personnel. Users could get the radiation value multiplying $\mathrm{CPM}$ by a conversion factor $(\mathrm{K})$ :

$$
\mathrm{CPM} \times \mathrm{K}(\mu \mathrm{Sv} / \mathrm{h})
$$

This conversion factor is achieved by means of a thorough calibration process by the manufacturer. In our case, this factor is valued in 0.008120 [18], thus the radiation received is derived in units of micro Sieverts per hour. The app shows Counts Per Minute (CPM), and Radiation Value $(\mu \mathrm{Sv} / \mathrm{h})$ at the same time. This is a new feature that commercial Geiger counters do not provide today.

It is important to note that the system is able to estimate the radiation value in real time and send this information to a database. This system contributes to monitoring radiation in two ways: (i) by acquiring/collecting radiation values in real-time and (ii) in the ability to store each radiation value labeling it with its corresponding date/time along with the user receiving the dose. Figure 2 shows how the proposed system works.

Nowadays, there are some alternatives, including GM detectors, which show radiation in real time, and in which data are also stored. To accomplish these functions, in [20], the device only ensures connectivity to a PC via USB, while the system proposed in [21] sets a proprietary system up to send data to a PC. Therefore, comparing with our proposal, the lack of remote communications incurs in a clear disadvantage. Furthermore, an additional advantage to our system, contrasted with similar systems such as the one mentioned above, is its low cost. Currently, this type of system is valued at thousands of Euros. In this sense, the work [22] tests a medical environment through a proprietary and costly solution, although in this case, remote communications are considered. We offer an alternative capable of improving current services at a much lower cost (the prototype proposed here does not exceed 200 Euros). 


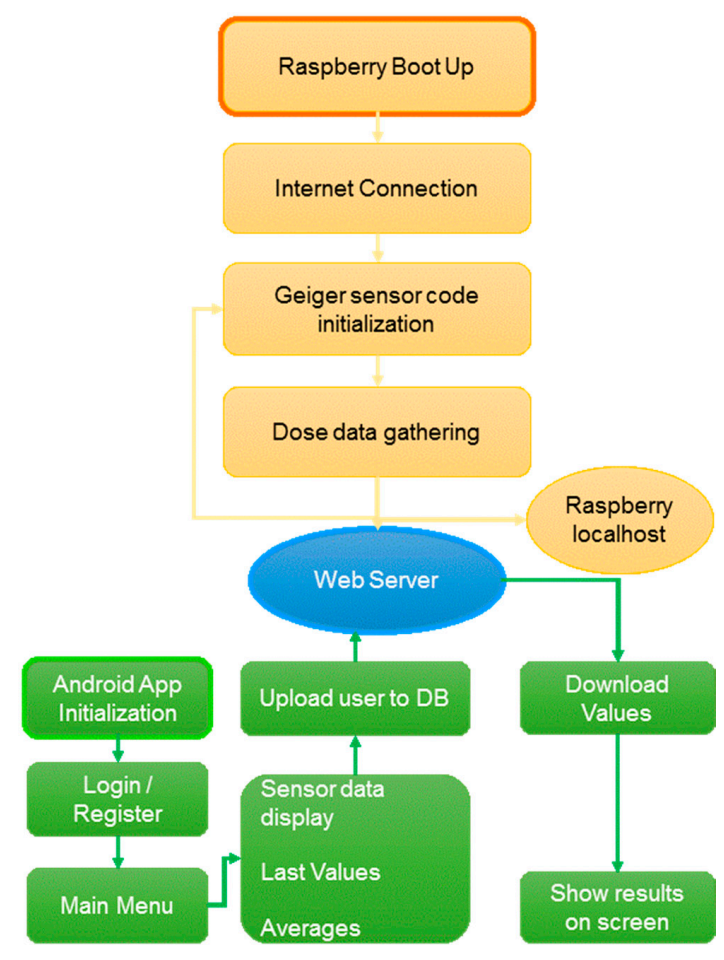

Figure 2. System's block diagram.

Different low-cost dosimeter-based solutions can be found in [23,24]. In [23], a dosimeter prototype captures the dose rate at $5 \mathrm{~Hz}$ through a CMOS camera. However, this proposal lacks communication support which prevents, for instance, statistics calculations. The work [24] leads to security concerns in power nuclear plant communications when data include radiation values. To face this, authors propose a solution based on XBee module communication, a well-known Wireless Sensor Network (WSN) device. Authors carefully explain aspects such as modulation, packet format or firmware, and how this device takes actions when malicious attacks occur; although they never evaluate its operation under the proposed nuclear environment.

The work [25] presented a low-cost, open-source and remote communication solution. In this paper, authors analyzed the variation of the energy in relation to the dose rate in a commercial and personal X-rays detector denoted as POKEGA. It is conceived to monitor the radiation received by members working in interventional radiology. The POKEGA solution was proposed in other works [26,27]; it is composed of a photodiode detector capturing the radiation, and a smartphone responsible for dispatching the dose (together with, for instance, GPS position, time, date, etc.) to Google docs, to later visualize the emplacement where each dose was collected. Both, photodiode and smartphone are connected by a cable. In comparison with our system providing reliability and robustness to the communication thanks to diverse wireless interfaces, POKEGA depends on the smartphone and its telephony connection. Furthermore, our system stores the monitored radiation both in a remote server and in the local device (Raspberry).

In summary, our system could be used as a personal and area dosimeter. It provides the advantages of displaying data in real time and storing it, either at an area level or for a specific user. In addition, the data reading procedure is more suitable and quicker than in the case of current personal dosimeters. 
These features are also ensured by its connectivity (USB, Ethernet, WiFi or 3G). So, this heterogeneous connectivity allows us to know the amount of received doses outside of the measurement location. It is notable that its connectivity, together with the ability to connect it to electrical current, guarantees robustness and reliability. Finally, the device has been verified by the CND simulating hospital conditions and validated in a real hospital environment, giving accuracy to our proposal as a real alternative.

\subsection{Advantages of Our Proposal in Respect to Current $\alpha, \beta, \gamma$ Radiation Meters}

The main advantages of our proposed system in respect to other proposals are the following:

1. Low cost. In comparison to other systems, the features and functions offered by our system are more competitive in terms of cost.

2. Double functionality. The device can be used for both personal (in specific places as, for instance, the CT room) and area dosimetry.

3. Real time doses. This system is capable of displaying the dose values in real time either as a personal or area dosimeter.

4. High storage capacity. In contrast to other current systems, our system has a large storage capacity, due to the database usage.

5. Statistics. Several statistics are calculated immediately by the remote server, available for users at any time.

6. Connection alternatives. The device is able to connect to remote databases through a set of interfaces (USB, Ethernet, WiFi and 3G).

7. Data recovery. If the device loses the connection to the remote database, all radiation values are stored in the device until the connection is restored.

8. Flexibility and modulation. The system is built using general-purpose and open-source technologies, which allows software/hardware modifications.

9. Easy access. Users can check the data everywhere, due to the fact that the interface is a smartphone app that is connected to the remote database.

10. Reliability. Different connection alternatives, replicated databases, and continuous energy supply contribute to a robust and reliable system.

11. Verification. The device has been verified in CND, under standard calibration protocols.

12. Easy handling and installation. Once the power is turned on, the device is automatically set to capture radiation, store it on the system and connect to the remote web service.

13. Authentication. Security tasks will be implemented in a future work; however, the user must register to access dose values.

14. Validation. This proposal has been validated at St. Lucia University Hospital in different environments, which will be further described in Section 5 .

Finally, Table 4 summarizes a comparison among different current radiation meters. This comparison is extended to include our proposal. 
Table 4. Comparison among different dosimeters including our system.

\begin{tabular}{ccccccccc}
\hline Device & Real Time & Reusable & Low-Cost & Internet & Database & Reliability & $\begin{array}{c}\text { Smartphone } \\
\text { App }\end{array}$ & $\begin{array}{c}\text { Open } \\
\text { Source }\end{array}$ \\
\hline TLD Dosimeter & No & Yes & Yes & No & No & Yes & No & No \\
Film Dosimeter & No & No & N/A & No & No & Yes & No & No \\
RPLGD & No & Yes & N/A & No & No & Yes & No & No \\
OSL Dosimeter & No & Yes & N/A & No & No & Yes & No & No \\
Personal Elec. Dosimeter & Yes & Yes & No & No & No & Yes & No & No \\
Pocket Dosimeter & Yes & Yes & Yes & No & No & No & No & No \\
Ionization Chamber & Yes & Yes & No & No & N/A & Yes & No & No \\
Proportional Counter & Yes & Yes & No & No & N/A & Yes & No & No \\
Geiger-Müller Counter & Yes & Yes & No & No & Yes & Yes & No & No \\
Scintillator Counter & Yes & Yes & No & No & N/A & Yes & No & No \\
Semiconductors detector & Yes & Yes & N/A & No & N/A & Yes & No & No \\
Instadose-Mirion & Yes & Yes & N/A & No & Yes & N/A & Yes & No \\
Dosicard-Canberra & $Y e s ~$ & Yes & N/A & No & Yes & N/A & No & No \\
PROPOSED SYSTEM & Yes & Yes & Yes & Yes & Yes & Yes & Yes & Yes \\
\hline
\end{tabular}

3.3. In Detail: Description HW/SW of the System

In the following sections, the system proposed here will be discussed in depth from a twofold perspective: (i) hardware components used, their connection/integration and (ii) software implemented.

\subsubsection{Hardware Description}

The device hardware is built as the integration of different printed circuit boards. These include:

1. A Raspberry Pi.

2. The radiation sensor board.

3. The Bridge board that connects the Geiger counter to the Raspberry Pi, denoted as Arduino Shield Connection Bridge.

Figure 3 shows the Raspberry Pi and Geiger Sensor, while Figure 4 depicts the entire system integrated and connected.

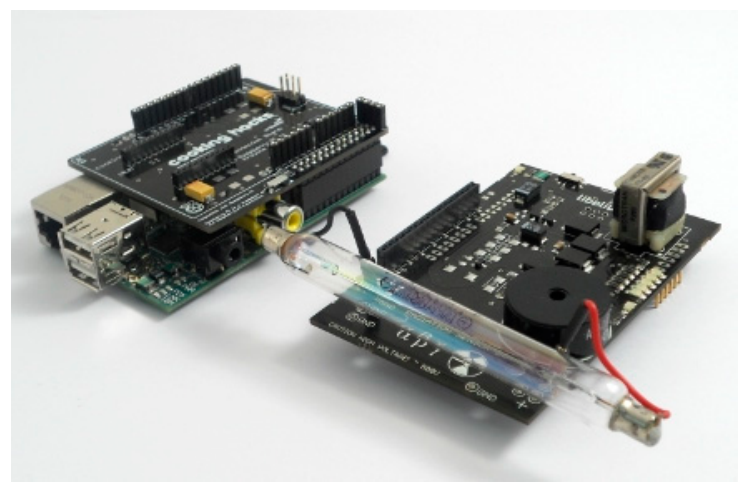

Figure 3. Raspberry Pi and Geiger Sensor (left) connected to the Bridge board and the Geiger Sensor board (right).

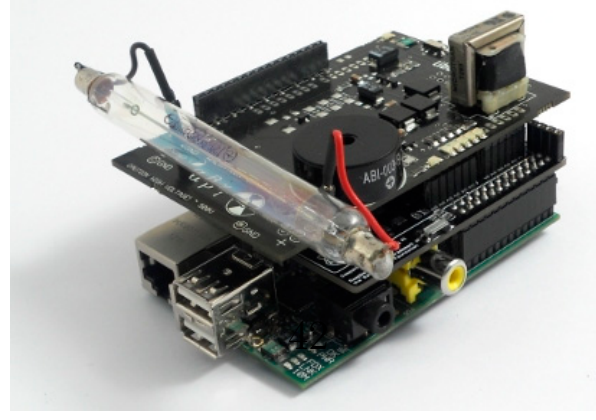


- Geiger Sensor Board [18]. This board is responsible for measuring radiation values using a Geiger-Müller tube. The radiation board is composed of two parts: the supply side and the signal side. The supply side is responsible for ensuring the high voltage required by the Geiger-Müller tube $(400 \mathrm{~V}-800 \mathrm{~V})$. The signal side adapts the output analog pulses from the GM tube to digital data understandable by the Raspberry Pi.

To achieve high voltage in the GM tube, an oscillator connected to a voltage multiplier consisting of diodes, transistors, resistors and capacitors is employed. This electronic circuit guarantees a potential difference of $500 \mathrm{~V}$. In the particular case of requiring voltage values above $500 \mathrm{~V}$ to feed the tube, they will be obtained from zener diodes connected in series.

- 3G dongle. When connecting to the Internet via 3G, it is necessary to put a 3G dongle into the interface USB of the Raspberry Pi. Although there are several models compatible with Raspberry $\mathrm{Pi}$, the selected dongle [29] together with a prepaid card have allowed the use of the device anywhere in the hospital environment. In addition, in the specific case of not having access to WiFi or Ethernet in the hospital under study, or when the system was verified at CND, the use of the $3 \mathrm{G}$ dongle has been essential to dispatch the captured radiation data to the remote web server.

- WiFi Adapter. This component is placed in a USB port, providing access to the Internet thanks to the WiFi hospital infrastructure. It should be noted that our device ensures an Internet connection (and therefore, the dose information for each user in the remote web server) by selecting of one these technologies: $\mathrm{WiFi}, 3 \mathrm{G}$ and Ethernet.

Figure 5 shows the complete system with 3G USB dongle connected.

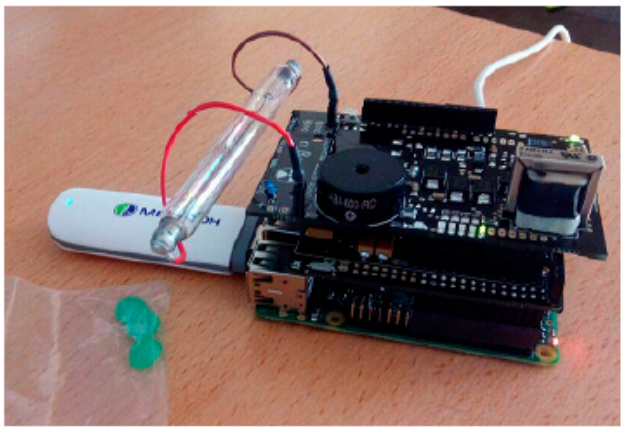

Sensors 2018, 18, x FOR PEER REVIEFigure 5. Device with 3 G dongle attached.

Figupe gdepicts the fomplete system inside the protection gover.

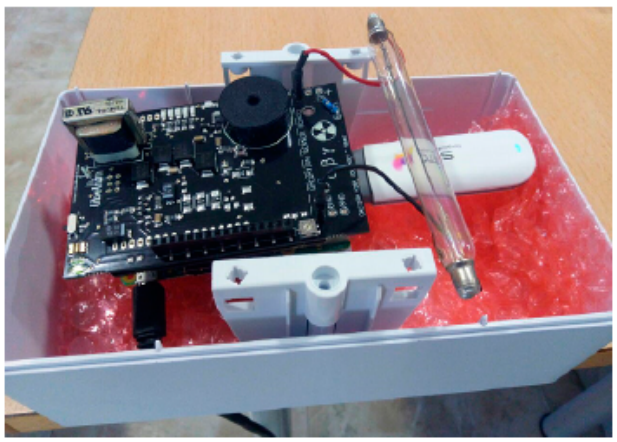

Figure 6. Cover case including device.

Figure 6. Cover case including device.

3.3.2. Software Description

1. Operating System. The operating system (P\$) for Raspberry Pi is denoted as Raspbian. In particular, Raspbian Jessie was the version installed, because it offers multiple functionality and documentation in terms of capturing data and communication issues.

2. Geiger sensor code. This code, implemented in Clanguage, quantifies the counts per minute and equivalent radiation measured by the GM detector on the board Raspberry Pi executes the 


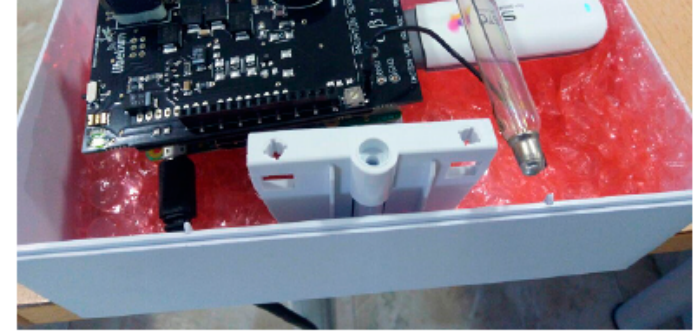

16 of 32

Figure 6. Cover case including device.

3.3.2. Software Description

3.3.2. Software Description

1. Operating System. The operating system (OS) for Raspberry Pi is denoted as Raspbian.

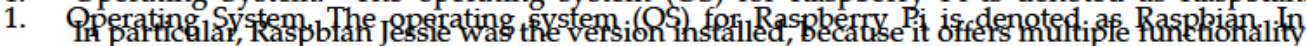
partigular. Rasphian Jessiewast the yersion installed because.it offers multiple functionality and

2. Goumentation in terms of capturing data and compunication issues

2. Geiger sensor code. This code implemented in G language, quantifies the kounts per minute and equivalent radiation measured by the GM detector on the board. Raspherry Pi.execptes the Brogrammed code obtaining the dose data from the Geiger detector through its cPIO pins. Sance the sensor uses the same connections as Arduino, it is necessary to include the arduPi library codes provided by the manufacturer.

Figufe 7 shows a flowchart 8f the way a Geiger sperates (and its asssciated code).

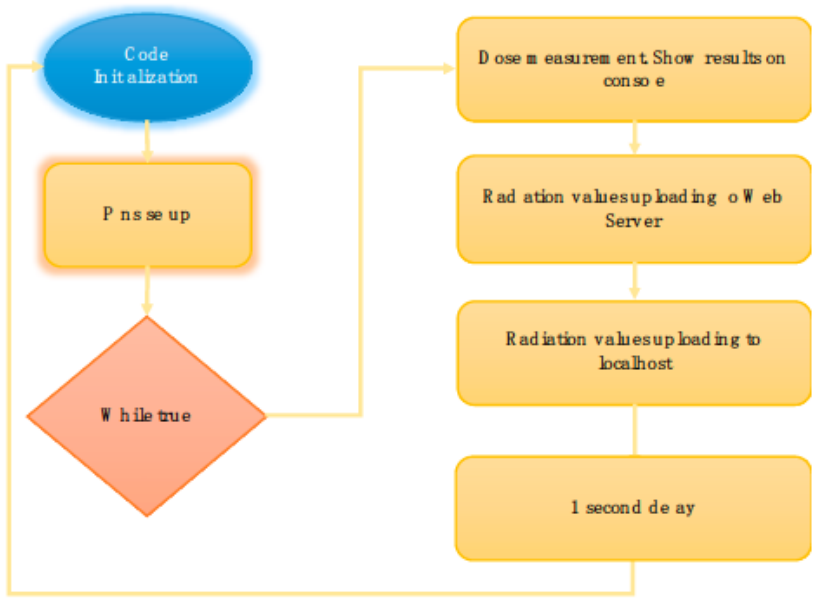

Figure 7. System general diagram.

Every time the code is initiated, the application remains waiting for a stimulation to occur in the GM tube, increasing the numper of counts. Then, the application enters into an infinite loop, in which the radiation values are continuously captured in periods of one second. In reference to the previous figure, each of the blocks is discussed:

- Radiation measurement: display by console terminal

- $\quad$ Radiation measurement: display by console terminal

As mentioned above, the app shows counts per minute (CPM) and radiation dose ( $\mu \mathrm{Sv} / \mathrm{h})$. Firstly, it is necessary to calculate the number of counts per minute and to later obtain the equivalent radiation value related to the CPM calculated, multiplying the CPM by the conversion factor provided by the manufacturer. The number of counts corresponding to the GM tube stimulation is stored in a specific variable. The temporal interval lasts one second. In order to obtain equivalent CPMs, it will be necessary to multiply the number of counts per second by 60 (countPerMinute $=60 *$ count).

Finally, before the radiation values are stored in the local and remote databases, the number of counts is reset (variable is set to zero), so when the loop is restarted, a new count value is obtained.

- $\quad$ CPM and radiation value upload to remote web server

Once CPM and radiation values have been obtained, the next step is to upload these data to the MySQL remote web server database. To this end, it is necessary to use a method which connects to the server by IP, user name and his/her password. Then, the programmer/developer selects the database 
which connects to it. Note that each device will have its own database on the web server. Thus, each device is independent of the other ones.

On the other hand, to upload the CPM and radiation values, a SQL query is implemented. In this case, programmers dispatch an INSERT type query, including countPerMinute (CPM) and radiationValue (equivalent radiation) values to the remote database. Finally, once these values have been stored, the connection is closed.

The results displayed by the smartphone application will be the data (together with their statistics) stored in this database installed in the remote web server.

- $\quad \mathrm{CPM}$ and radiation value storage in localhost

The dose values are also stored in the localhost database.

Any error detected in the remote web server will be mitigated by the localhost. That is, those radiation values which were lost in the period of non-operation of the web server will be recuperated by the localhost. This function is carried out by a method which shares the same code as the previous one, except for the IP address.

\section{- $\quad$ End of loop}

Finally, once data has been uploaded to the web server and stored in the localhost, there is a one second delay in the following set of measurements. This delay implies an appropriate time interval, from the time the radiation level is measured by the Geiger detector, to the time the Android application displays this value on the screen. If the delay decreases to values inferior to one second, the GM detector would be able to measure more accurately. However, there would not be enough time to upload the data to the web server and download it onto the app. It is notable that other systems are capable of showing radiation levels, but taking more time, demonstrating that this system is more accurate in adjusting the intervals to radiation samples.

Finally, an automatic code startup has been implemented. To avoid the manual execution of the code in Raspberry Pi (resulting in inefficient application in hospital environments), a script has been programmed to automatically start the code every time the Raspberry $\mathrm{Pi}$ is connected to a power supply or is booted. To this end, as Raspberry Pi is a Unix system, the script will be created within the /etc./init.d directory, in which the start and stop commands are specified. Additionally, the different interfaces to access Internet (WiFi, 3G and Ethernet) will also connect automatically, without requiring support from specialist personnel or developers.

3. Servers. A server is required to store the dose data collected by the device. The one selected for both the remote web server and the localhost is Apache [30], which is a free-service and open-source HTTP server with the same features as other high-cost competitors. The Apache web server is responsible for storing the GM-captured radiation data and managing them in an Android application. In this case, the Android application accesses this server, both to log in or register a new user, and to display the radiation measurements/statistics. The remote web server requires Internet access, so, it must have a domain and therefore, a public IP address. In a certain way, both the device and the Android application connect to the server through this public IP. Under this premise, note that a web server allows us to access data anywhere. Using the Android application or a PC, we check the radiation values at any time and place, even if the detector fails or turns off. This also allows us to control the login and registration of users, avoiding, for instance, that two different users employ the same user name. The Apache localhost is configured as a backup service, lacks an Internet connection, and data are recovered via USB.

4. Database. They are responsible for storing both radiation data from the GM detector and information from user registers. PhpMyAdmin [31] has been selected as the tool to generate database, both in the local server and the remote web server. PhpMyAdmin written in PHP ensures the database management and handles the MySQL facilitates. For instance, the user can 
create/delete databases, generate/delete/modify tables, delete/edit/add fields, execute any SQL statement, handle keys in fields, manage privileges, and export data in various formats.

Keeping in mind that the devices are independent from each other, labeling each device with its own unique identification number means that each device has its own database. The result is a more intuitive and appropriate management of different devices deployed in a hospital, thus facilitating the data recovery and the data security.

The fields composing the databases are, as well as the CPM and radiation value, the following: (i) an identifier for each measurement uploaded; (ii) a timestamp of the captured dose, both coming from the device; and (iii) registered users, including user name, password and email data, dispatched by the smartphone application. Regarding the latter, the goal is for each hospital to have its own databases of users, which would be independent of the others.

5. Android application. The application developed for smartphones is in charge of displaying all the radiation results captured by devices. This application has been implemented in Android because, among other factors, it is an open source. Furthermore, Android makes the simulation and testing of different versions of our application on different devices easier, without the requirement of them having been previously developed in emulators. The development of the app is divided into two main parts: The appearance, focused on the graphic interfaces and the specific functions of each of them.

Figure 8 presents a flowchart including the overall functionality of the app.

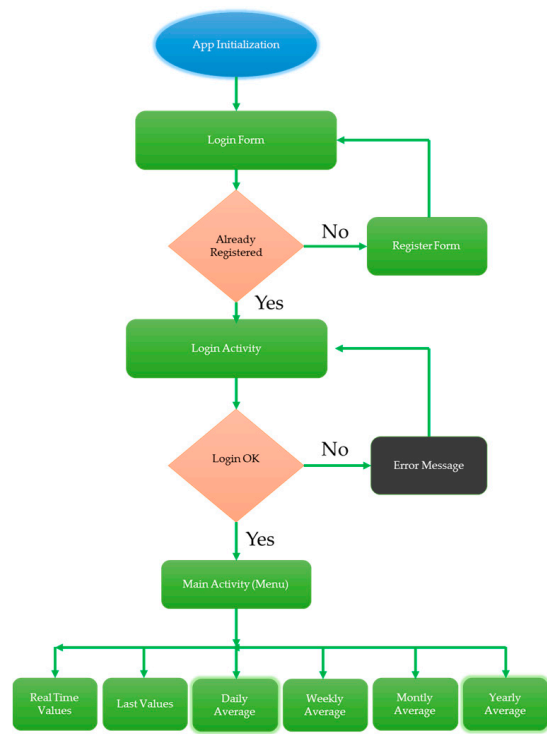

Figure 8. App flow-chart.

The application links the database through SQL queries. These communications are asynchronous due to the fact that the server runs diverse processes, so this issue will stop the main application if it is coded in a synchronous way. To implement asynchronous tasks, the AsyncTask class [32] is employed. This communicates with the process of the main thread, only performing operations and showing the results in the main thread.

An advantage of our implementation is the reduction of the number of database accesses. So, the application is more efficient and dynamic, decreasing the probability of connection errors. To this end, the Intent class [33] is in charge of sending the user name and device number, among 
different activities, without requiring remote connection to the database. Therefore, SQL queries are only demanded when users want to obtain some type of results, such as radiation statistics. Finally, in the following subsections, the appearance and function of each of the parts in which the app has been divided will be detailed, according to the general diagram shown in Figure 8.

App Initialization

Each time the app is started, an image, like in Figure 9, presenting a login form, appears.

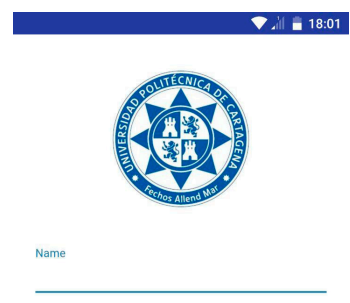

$\underline{\text { Password }}$

Device Number

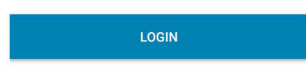

No account yet? Create one

Figure 9. Login screen.

As shown, this form inputs the user name, password and device number. First of all, the user name linked with the password is required. Those values are stored in the database.

The device number is the identifier assigned to each device. Each hospital has a specific number of catalogued devices, allowing the user to select the device which they want to receive radiation information from. This selection is manually accomplished when logging in, and depends on the area where the staff is working. Therefore, by filling in the device number field, the app connects to the database corresponding to that device. This is possible because, as discussed above, each healthcare worker is exposed to radiation in an enclosed hospital area, and it will not be necessary to modify the device number every time.

On the other hand, if the user doesn't input data in the form fields or a device number is not one of those assigned to the hospital, an error message will be shown, alerting the user. The Inputvalidation class is in charge of these functions. However, if the proccess is correct, the Login button is enabled and the user name and password are checked against the database through the CheckUser class. In the affirmative case, the main view of the application is depicted in Figure 10. 


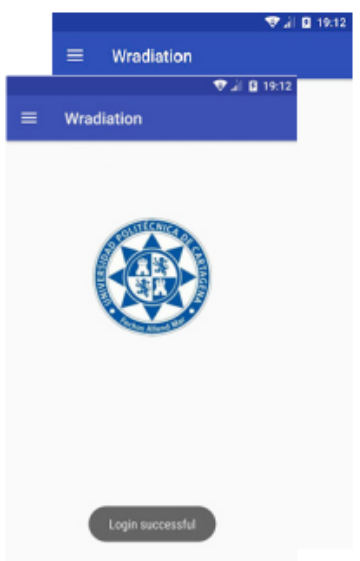

19 of 30

Figure 10. Login successful

Figure 10. Login successful.

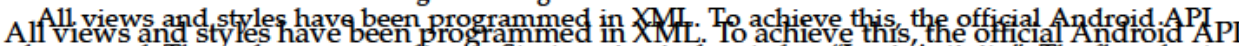

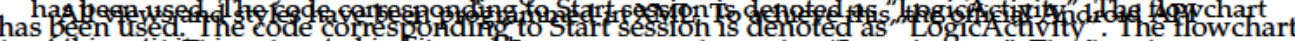
ha of this activity is presented in Figure 11 .

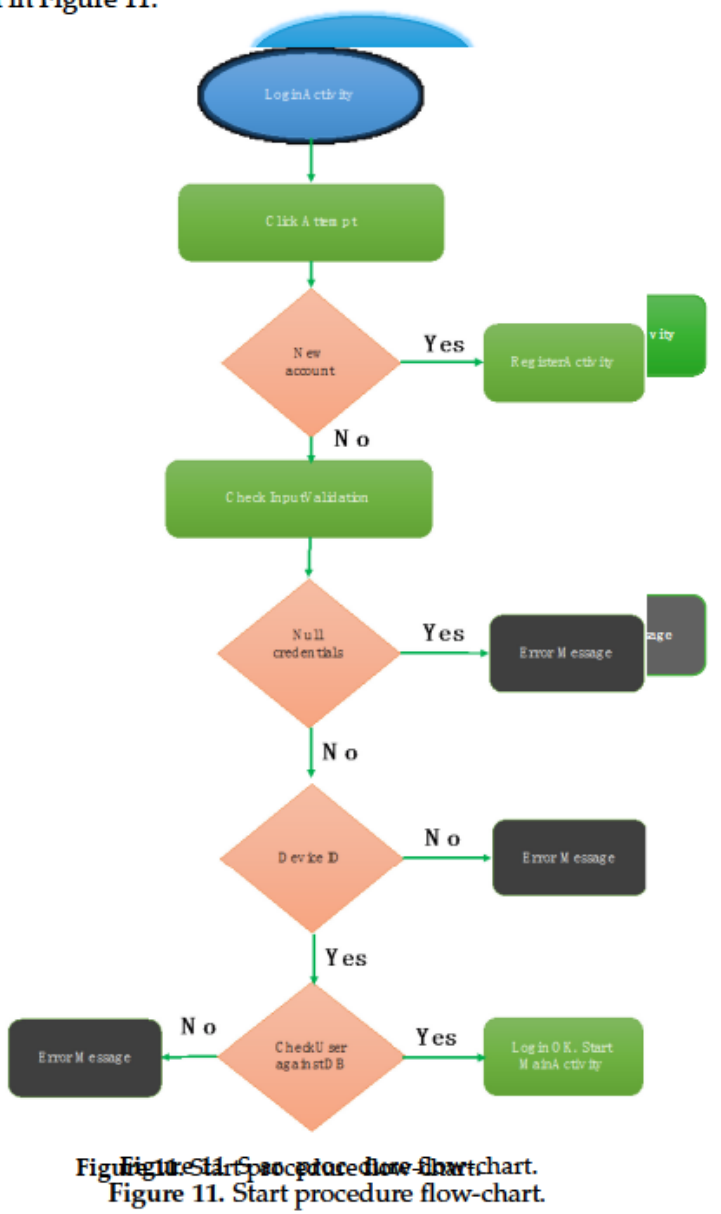


User Register

Each time the user clicks on the screen "No account yet? Create one", located in "LoginActivity", the activity called "RegisterActivity" will start. This activity shows a registration form, as shown in Figure 12.

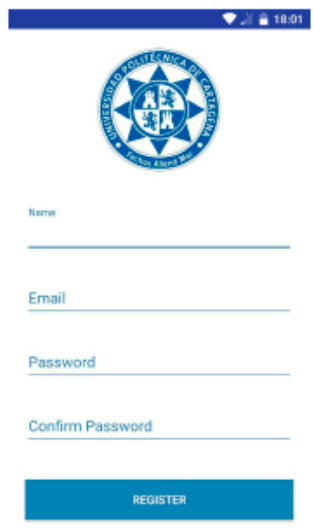

Figure 12. User registration.

As we can see, this form asks for the user name, e-mail address, password and password confirmation of the user. As in "LoginActivity", the login form is accessed again by clicking on the sentence "Already a member? Login", shown in the following Figure 13.

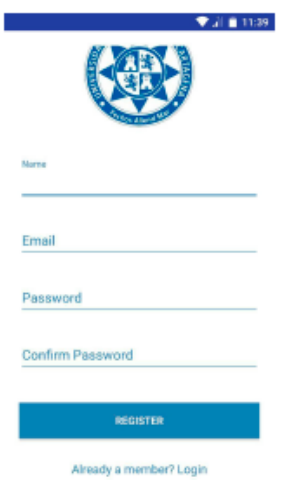

Figure 13. App login screen.

"RegisterActivity" contains the same features as "LoginActivity". The InputValidation class executes a function in charge of ensuring that if the user introduces empty fields in the form or if the password field does not match the confirm password field, an error message will alert the user. The class CheckUserRegis, extended to the class AsyncTask, checks if the application has a user name which already exists, thus comparing the one introduced in the application with the user's database. Finally, if a user name doesn't match a previous one introduced in the database, it means that this name is available and the new user's data is stored in the database. The class responsible for this function is called AddUser. The following flowchart summarizes how this activity works (Figure 14). 


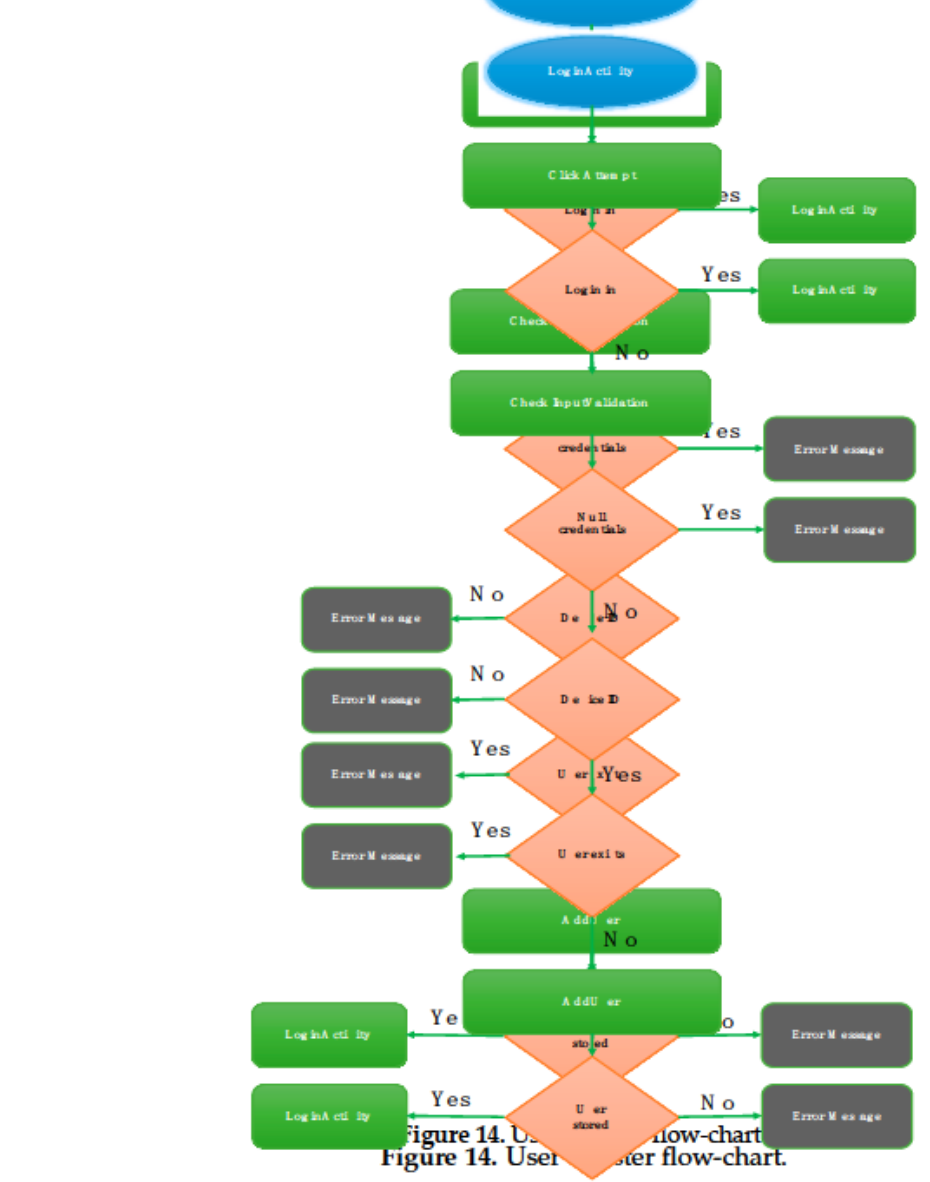

Main Menu

Figure 14. User register flow-chart.

Main Meñhe appearance of the main menu corresponds to the Technical University of Cartagena (UPCT) Mainaspanl as a dropdown menu which lets us select the action we want the device to furnish is
The appearance of the main menu corresponds to the Technical University of Cartagena (UPCT)

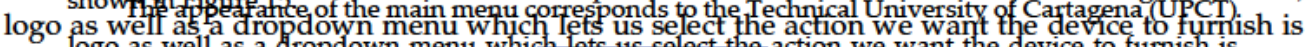
logo as well as a dropdown menu which lets ws selest the action we want the device to furnish is shownin Figure 15.

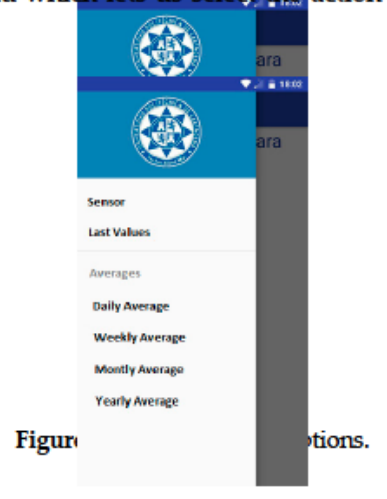

Figure 15. App statistical options.
Figare 15. App statistical options. 
Each menu item is associated with a different activity: A particular case is the "Sensor", action, which shows GM detector (sensor results in real time: The Adain Activity allows a user who requires any stadistical action, for example, to download the monthly average radiation, to finish this action, and again access real time dose values in their smartshone: Fhe goal is to provide an extra function to the main menu, which goes gevond an intermediary between activities. Finally, the function corresponding to the main activity is "MainActivity", and is reflected in the following flowchart (Figure 16):

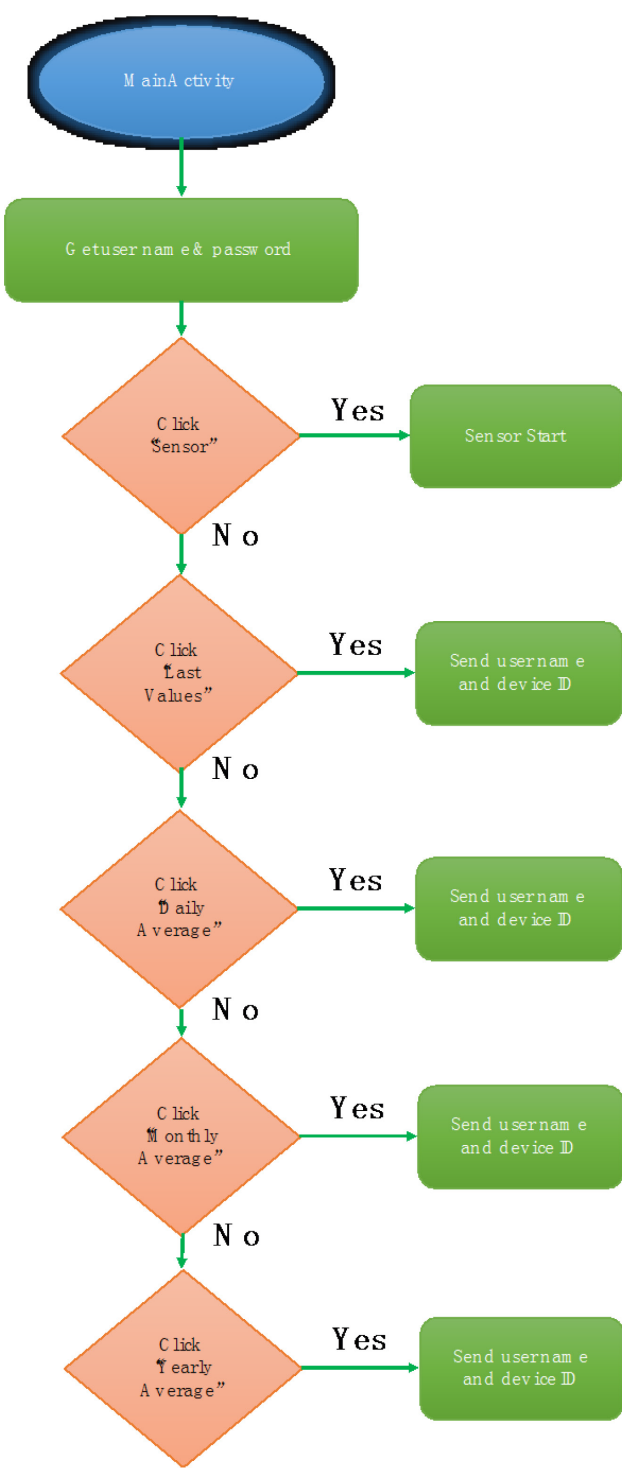

Figure 16. Main menu method flow-chart.

As shown in Figure 16, depending on the item of the dropdown menu which the user clicks, one action or another starts, and'then, a different activity begins As previously illustrated in the "Intent" one action of another tarts, and then a different activity begits As previously illustrated in the
description, before starting a new activity, the user name and device number are obtained from "LoginActivity". 
"Intent" description, before starting a new activity, the user name and device number are obtained from "LoginActivity".

\section{แ1! \\ =ำ \\ sensors}

nented in the "MainActivity", sharing appearance and function the dropdown main menu. The appearance depends on its state. If the "Sensor" icon has clicked by the user to start collecting and displaying values in real time, the following Figure .. u r.m. the graphic user interface which appears. However, if the user clicks the "Sensor" icon, the window is Figure 18.

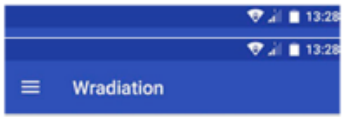

Click Sensor to Start

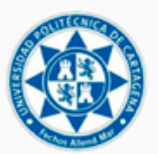

Figure 17. Main screen.

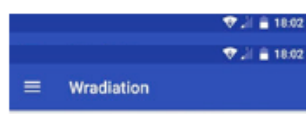

Real Time Data

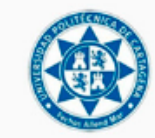

CountPerMinute

6

radiationValue: 0,04872

User:

Pedro

Figure 18. Dose values screen shot.

Values belong to counts per minute (CPM) and their corresponding radiation value, together with the user who has downloaded them, as shown in this view (Figure 18). These values are updated each second, collected by the GM detector. If the device turns off, the last value captured by the sensor is displayed. Note that the appearance changes (each second) once the first SQL query arrives to the database. The Query class directs this issue. 
Showing Last Values

This activity addresses the last counts per minute (and thus, radiation values) and the timestamp registered by the user device as well. The activity in charge of this function is Main2Activity. However, the class which leads to the connection to the database is Last class. This furnishes the required operations to obtain last dose values by means of SQL queries as shown in Figure 19.

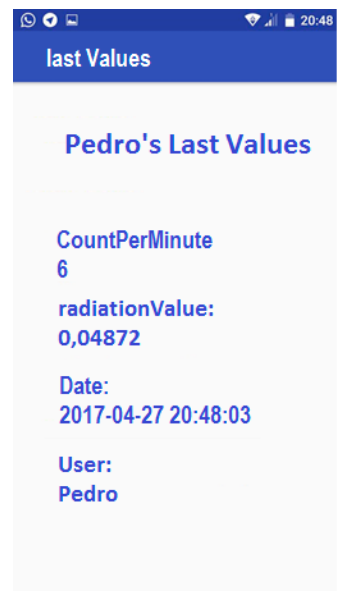

Figure 19. Last values screen shot.

\section{Statistics}

The appearance and functionality for the daily, weekly, monthly and annual average is the same. Only the SQL queries vary, taking into consideration the time period to compute. The statistic view shows the user name, the device number and the average value that is required to download from the remote database. The function is similar to the previous Last Values view. However, they are very different in the SQL query message. In detail, the activity addressed to the daily average is Main4Activity and the attachment to the database is carried out by the diarilyaverage class. Regarding the weekly average, it is accomplished by Main5Activity and the weeklyaverage class. The monthly average is run by Main3Activity and the Middle class. Finally, for the annual average, Main6Activity, together with the MediaAnnual class exhibit the annual statistics. These codes, together with the complete software here proposed, are available in [3].

\section{Verification of the Device}

To guarantee the reliability and traceability of radiation measurements, it is necessary to verify the appropriate operation of the device in hospital environments. The verification procedure was carried out in the Laboratory of Ionizing Radiation Metrology at the National Dosimetry Center (CND). The CND is the largest Personal Dosimetry Service in Spain, and one of the largest in Europe in terms of monthly reading volume. It has been authorized for this purpose by the Nuclear Safety Council. Likewise, the National Dosimetry Center has been authorized to act as a Radiological Protection Unit in radio diagnostic installations.

The CND has an Ionizing Radiation Metrology Laboratory, available to the public healthcare sector and private initiatives. The calibration laboratory was certified by the National Accreditation Agency (ENAC) for calibrations in ionizing radiation and radioactivity. The certification is also recognized by the European Organization for Accreditation of Laboratories (EA). The Laboratory performs calibration of instruments for measuring ionizing radiation, as well as irradiation of personal dosimeters (DTL, film dosimeters, etc.), at protection and diagnostic levels. 


\subsection{Verification Procedure}

The verification performed on the system corresponds to the PT-03 procedure, which is characterized in the certification of instruments for measuring ionizing radiation under X-rays.

To furnish the procedure, the device was set-up in the Test Room without any external casing, taking the center of the GM tube as a reference point. In this room, the device was put in a vertical position, orienting the GM tube towards the X-ray source, so that the tube was parallel to the anode-cathode direction.

In order to obtain the best measurement quality, the reference point was matched to the center of the radiation field. This was accurately marked by a laser, so the device was displaced to that point, as can be seen in the sequence of images in Figure 20.

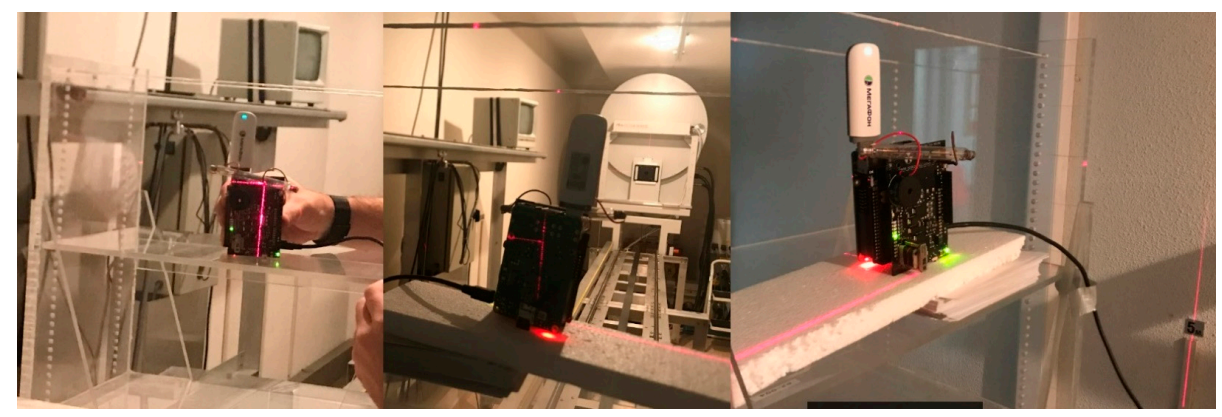

Figure 20. Device verification sequence.

The distance between the X-ray source and the reference point is $5 \mathrm{~m}$. The appropriate radiation field diameter is $19 \mathrm{~cm}$, capturing the radiation dose in the GM tube. The radiation qualities employed in the verification process are defined as N-80 and N-300 of the Narrow Spectrum ISO Series. The characteristics of these radiation qualities are broken down in Table 5, below. Note that Kerma is the sum of the kinetic energies of all charged particles set in motion by the radiation; its magnitude in the international system is the Gray, equivalent to a 1 Joule per Kilogram. On the other hand, the so-called half-value layer (HVL) is the layer thickness of copper reducing the intensity of radiation due to absorption and scattering phenomena by half (first half-value layer) and by four times (second half-value layer), respectively. As it will be observed in the next subsection, one of the test was carried out in the PET surroundings. In this device, the energy peak is $511 \mathrm{keV}$ around, value that is out of the range of the N-300 quality. However, in usual medical tests where the radionuclide is inside the human body, the continuous spectrum generated is lower than the maximum peak. This fact is even greater in our case since we measure doses in the PET surroundings. Therefore, the N-300 quality is, a priori, appropriate to validate our device under these conditions. This also is in accordance with the CND standards. On the other hand, $\mathrm{N}-80$ is the spectrum recommended for X-rays which usually varies from 20 to $125 \mathrm{keV}$; N-80 is selected as a central energy value.

Table 5. Main features for N-80 and N-300 Qualities.

\begin{tabular}{ccccccc}
\hline Quality & Voltage & $\mathbf{E}_{\text {avg }}$ & 1st HVL & 2nd HVL & Kerma (Air) $(\mu \mathrm{Gy} / \mathbf{m i n})$ & Kerma (Air) $(\mu \mathrm{Gy} / \mathbf{m i n})$ \\
\hline Code & $\mathbf{( K v )}$ & $\mathbf{( k e V )}$ & $\mathbf{( m m ~ C u )}$ & $\mathbf{( m m ~ C u})$ & Minimum & Maximum \\
\hline N-80 & 80 & 65 & 0.05776 & 0.619 & 1.9 & 1000 \\
\hline N-300 & 300 & 250 & 6.28 & 6.29 & 2.9 & 450 \\
\hline
\end{tabular}

Thus, the verification process performed is summarized in Table 6. 
Table 6. Verification procedure for N-80 and N-300 Qualities.

\begin{tabular}{cccc}
\hline Quality Code & System Scale & Kerma Air Rate $(\mu \mathrm{Gy} / \mathbf{h})$ & Radiation Time \\
\hline N-80 & 100 & $110-130$ & 360 \\
N-80 & 100 & $180-210$ & 360 \\
N-300 & 100 & $350-400$ & 180 \\
\hline
\end{tabular}

Table 6 exhibits the three tests performed on our device. They were defined by the CND according to the environment where our system will be deployed. Additionally, a thorough study should be carried out to enhance the GM measurement accuracy. For instance, in a future, a correction factor which reflects the difference between the response of the commercial GM in relation to the dose rate could be computed, to later program it in the Raspberry.

As regards the tests, firstly, an N-80 was implemented with a radiation range from 110 to $130 \mu \mathrm{Gy} / \mathrm{h}$, at an interval of $360 \mathrm{~s}$. The second test was carried out with similar characteristics to the previous one, but increasing the radiation level from 180 to $210 \mu \mathrm{Gy} / \mathrm{h}$. Finally, an N-300 test was furnished with a radiation range from 350 to $400 \mu \mathrm{Gy} / \mathrm{h}$ for an interval of $180 \mathrm{~s}$.

In each test, the radiation values captured/sensed by the device were written down in Table 7. Later, these values were compared to the radiation values measured by the certified laboratory instrumentation at the same time interval. Thus, the relationship between the values captured by the device and those collected by the laboratory instrumentation results in an $\mathrm{N}_{\mathrm{H}}$ verification factor. This factor must be multiplied by the radiation values measured by the device to obtain the true radiation values.

\subsection{Verification Results}

The verification results are shown Table 7 below.

Table 7. Verification results for our proposal.

\begin{tabular}{ccccc}
\hline Quality Code & System Scale & Kerma Air Rate $(\mu \mathrm{Gy} / \mathrm{h})$ & Radiation Time & $\mathbf{N}_{\mathbf{H}}$ \\
\hline N-80 & 100 & $110-130$ & 360 & $3.37 \pm 0.20$ \\
N-80 & 100 & $180-210$ & 360 & $5.28 \pm 0.58$ \\
N-300 & 100 & $350-400$ & 180 & $10.2 \pm 1.0$ \\
\hline
\end{tabular}

Concerning the first $\mathrm{N}-80$ test, the verification factor $\mathrm{N}_{\mathrm{H}}$ is 3.37 with a deviation of \pm 0.20 . The second $\mathrm{N}-80$ test results in a $\mathrm{N}_{\mathrm{H}}$ factor of 5.28 with a deviation of \pm 0.58 . Finally, for the last $\mathrm{N}-300$ test, the verification factor $\mathrm{N}_{\mathrm{H}}$ is 10.2 with a deviation of \pm 1 . Observing these results, we notice that as the radiation level increases, the radiation factor also grows considerably, having to multiply the radiation value of our device by 10.2 in the case of N-300 quality.

However, a last correction factor (which has been denoted as $\mathrm{N}_{\mathrm{F}}$ ), motivated by the sampling period to which the GM tube is subject, must be considered. This factor adjusts our sampling times (1 s) to the one defined by the manufacturer (10-s blocks). In other words, by dividing the sampling period indicated by the manufacturer by 10 , the sampling period under study is obtained, and then the CPMs are calculated. Therefore, the final verification equation is as follows:

$$
\text { Real Radiation Measurement }=\text { Captured Radiation Level }{ }^{*}\left(\mathrm{~N}_{\mathrm{H}} / \mathrm{N}_{\mathrm{F}}\right) \text {, }
$$

where NF $=10$.

This means that for the N-300 radiation quality, the standard deviation obtained in the verification process at the CND is the only one that computes. 


\section{Performance Evaluation in the Hospital}

The main contribution of this work is to offer a step forward in radiation measurement systems and in particular, those affecting healthcare personnel. As a final issue in the development of the proposal, it was tested in a hospital environment under real conditions.

Two devices were configured to be tested at St. Lucia University Hospital in Cartagena. A device was placed in the corridor adjacent to the Nuclear Medicine department (near the Positron Emission Tomography room, Figure 21), specifically, in the same place as the current area dosimeter. The device continuously measured the ambient radiation for $7.5 \mathrm{~h}$. Its main purpose was to capture the radiation emitted by patients who walked by and stayed in this area.

The second device was located in the CT area, specifically, in the room where the healthcare staff control the procedures (Figure 22). As in the previous case, this device measured environmental radiation. However, the radiation received by the healthcare staff was collected, measured, stored and computed in our databases and smartphone application.

An additional dosimeter was placed into our device cases for comparison purposes after the

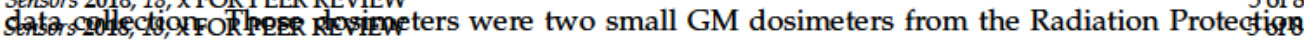
Bepartment at Sta: Eucia University H8spital : Fhe goal was t8 contfast the accumfllated radiation in

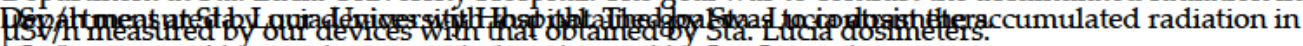
$\mu S v / h$ measured by our devices with that obtained by Sta. Lucia dosimeters.
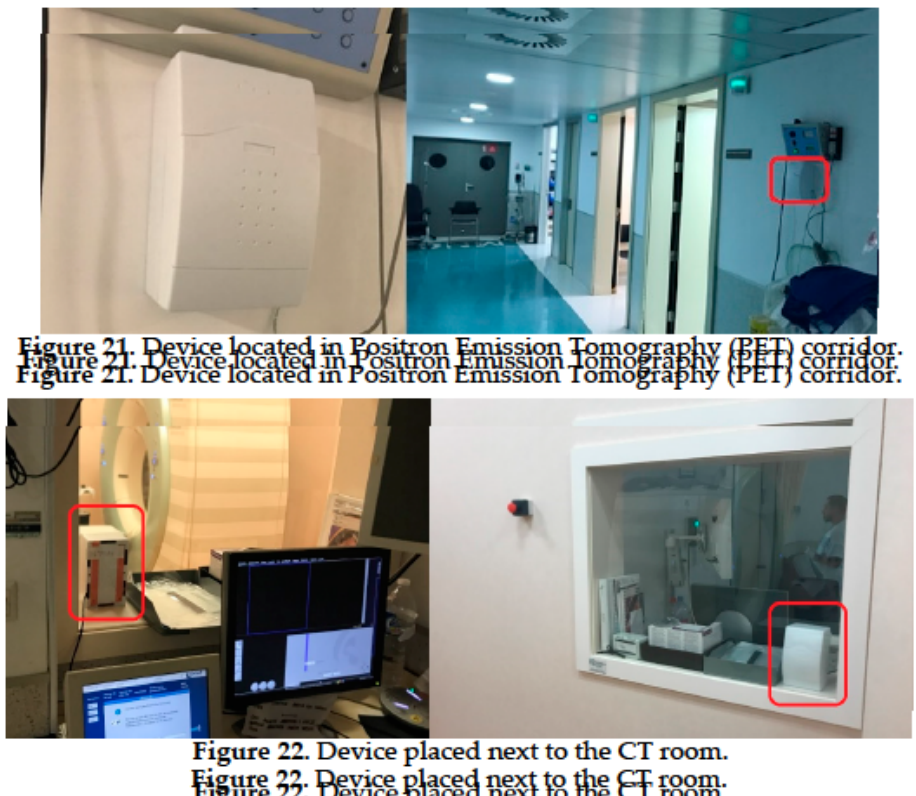

Result Discussion

Result Discussion

Resulthesfussfafion values obtained by the devices can be observed in Figures 23 and 24. Figure 23

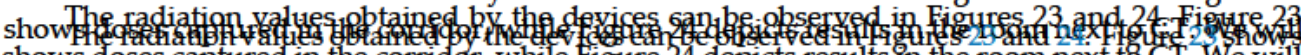

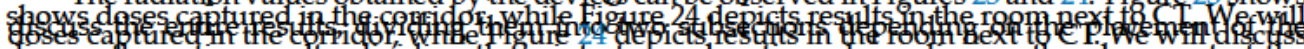
disciss the entire results, dividing them into two subsections depending on the placement of the gistess the entire results, dividing them into two subsections depending on the placement of
devices.

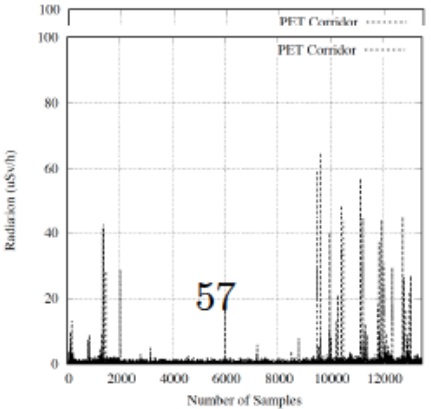

Figure 23. PET corridor results.

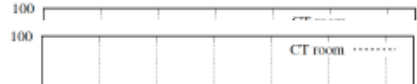




\section{Result Bištussibn}

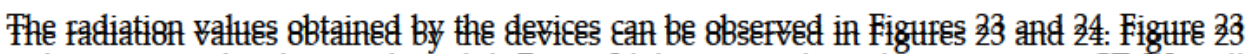

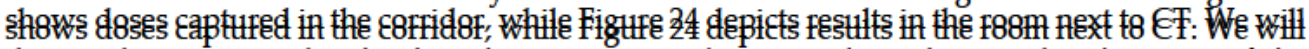

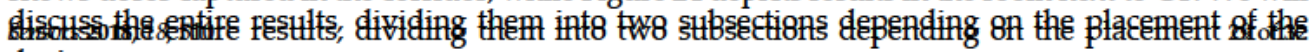
devices:

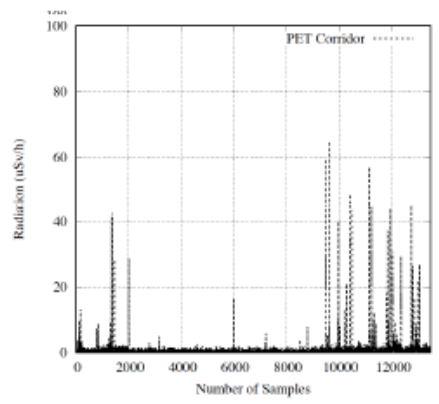

Figufe 23:: PE€ E8fridgf fesults:

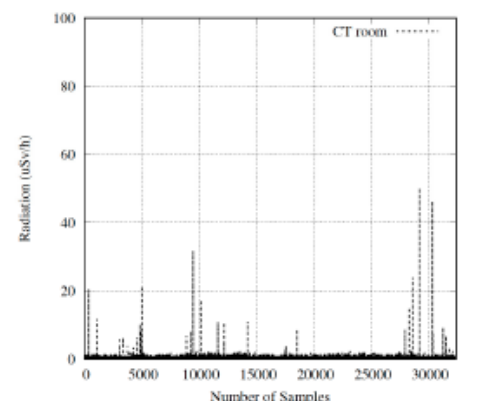

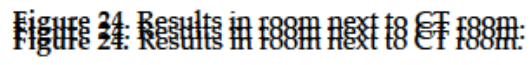

Device Located in the Corridor

Before starting the tests, it was verified that the environmental radiation value captured by the device was similar to the one measured by the area dosimeter belonging to St. Lucia University Hospital. In detail, the latter obtained a dose range from $0.005 \mu \mathrm{Sv} / \mathrm{h}$ to $0.5 \mu \mathrm{Sv} / \mathrm{h}$ in a period of ten minutes. During the same interval, our device collected a radiation range from $0.0044 \mu \mathrm{Sv} / \mathrm{h}$ to $0.4872 \mu \mathrm{Sv} / \mathrm{h}$.

As shown in Figure 23, we can observe that the radiation values increase to a maximum value (peak) and then they decrease gradually. As expected, a patient in treatment increments the activity of the device. Therefore, when values grow, it indicates that the patient is approaching the device. The maximum radiation value points out that the patient is closest to the device. Finally, as the patient moves away, the radiation values decrease.

Results were compared to the portable GM device at St. Lucia University Hospital. Our platform obtained an accumulative radiation of $2.46 \mu \mathrm{Sv} / \mathrm{h}$, compared to the $2.12 \mu \mathrm{Sv} / \mathrm{h}$ of the hospital device during the time period evaluated. All in all, the viability and operation of our system as an area dosimeter is demonstrated, and validates the design and development proposed. Furthermore, these results can be displayed in real time, thanks to the app, or later analyzed, by dispatching data from the database (e.g., PC).

\section{Device Located in the Room Next to CT System}

Once installed and configured, the device was checked to observe if it captured radiation values when patients were scanned in real time. This task was carried out by two healthcare staff members, downloading and using the smartphone application, simultaneously. The result was that both received an accumulative dose of $0.45 \mu \mathrm{Sv} / \mathrm{h}$ in their working day (eight hours).

Figure 24 shows the radiation values received by personnel during an $18 \mathrm{~h}$ period. As can be observed, the number of samples indicating a radiation level above the background value is lower 
than in the previous case. Therefore, the time dedicated to a complete CT scan is shorter than the radioactive pharmacological treatment received by a patient.

On the other hand, as in the corridor device, data obtained was compared to the portable GM device at St. Lucia University Hospital. Our platform obtained an accumulative radiation of $1.86 \mu \mathrm{Sv} / \mathrm{h}$ in comparison with the value of $2.09 \mu \mathrm{Sv} / \mathrm{h}$ measured by the hospital device during the time period evaluated, validating our system as a personnel dosimeter for specific areas. As in the previous case, these results can be monitored in real time or later, by transferring data from the database.

In both scenarios, it is noteworthy to mention that medical devices barely interfere in the communications of our devices due to the distances among them. This means that packet losses motivated by interferences are scarce, ensuring that data dispatched each second by the device are in turn received by the mobile application. Additionally, medium access mechanisms such as CSMA-CA (Carrier sense multiple access with collision avoidance) in WiFi support packet collision; the device transceiver senses the physical medium and, only when it is free of interferences, sends the packet including the collected dose.

\section{Conclusions}

In this paper, we propose the design and implementation of a low-cost, open-source, portable, COTS system to collect ionizing radiation (gamma particles) in real time, deriving (i) the average radiation in different temporal periods and (ii) the accumulated radiation received by medical personnel. The solution is offered by a device that contains a commercial Geiger-Muller detector and all the electronic boards required (hardware and software) to dispatch the dose values to a remote database. Healthcare staff will obtain information of the radiation received in their bodies through a mobile application, developed in Android, and connected to the database.

To validate the complete system, a twofold procedure was adopted. Firstly, it was verified in the CND Calibration Laboratory, an authorized and accredited center for this type of calibrations. Secondly, a test-bed was set up at Sta. Lucia University Hospital, deploying two devices in two potential radiation areas and comparing measurements with other validated dosimeters placed next to our devices. Results show that this solution is able to accurately measure the radiation doses received by two heathcare workers in real time, and generate statistics for later studying and analyzing. Finally, the system proposed appropriately operates as a general purpose area dosimeter.

Acknowledgments: This research has been supported by the project AIM, ref. TEC2016-76465-C2-1-R (AEI/FEDER, UE). This work is dedicated to the memory of Felipe Garcia-Sanchez.

Author Contributions: A.-J.G.-S. conceived the idea. E.A.G.A. and P.A.M.R. looked into the related literature. A.-J.G.-S. proposed the scientific methodology. A.-J.G.-S. and P.A.M.R. contributed to the HW/SW definition. E.A.G.A., A.S.B. and D.R.-A. improved technical issues. All authors participated in the elaboration of the manuscript and its revision.

Conflicts of Interest: The authors declare no conflict of interest.

\section{References}

1. Richardson, D.B.; Cardis, E. Risk of cancer from occupational exposure to ionising radiation: retrospective cohort study of workers in France, the United Kingdom, and the United States (INWORKS). BMJ 2015, 351. [CrossRef] [PubMed]

2. Directive 2013/59/Euratom. Available online: https:/ / ec.europa.eu/energy/sites/ener/files/documents/ CELEX-32013L0059-EN-TXT.pdf (accessed on 17 December 2017).

3. Solution Code. Available online: https://www.dropbox.com/sh/38g9yr34loyeb4h/AADk0q KMaN7FYKICt0sCkgga?dl=0 (accessed on 17 December 2017).

4. Gilmore, G.R. Practical Gamma-Ray Spectrometry, 2nd ed.; John Wiley \& Sons: Hoboken, NJ, USA, 2008. [CrossRef]

5. TLD Dosimeter for RE-2000 Readers. Available online: http:/ /nusim.com/wp-content/uploads/2012/07/ 20996042_TLDdosimeter_EN_A.pdf (accessed on 17 December 2017). 
6. Noriega Sánchez, K.; Ruiz Manzano, P. Dosimetría de Cristalino de GESTISA y Su Aplicación a Personal. $4^{\circ}$ Congreso Conjunto Sociedad Española de Física Médica (SEFM) y la Sociedad Española de Protección Radiológica (SEPR), Valencia, 2015. Available online: http://www.crystallineproject.eu/wp-content/ uploads/2015/06/SISTEMA-DOSIMETRIA-GESTISA-Y-APLICACION-AMBITO-SANITARIO-pdf.pdf (accessed on 17 December 2017). (In Spain)

7. European Nuclear Society. Film Dosimeter. Available online: https://www.euronuclear.org/info/ encyclopedia/f/filmdosimeter.htm (accessed on 17 December 2017).

8. LLNL Environmental RPL Dosimeter. Available online: https:/ /www.orau.org/PTP/collection/dosimeters/ ron.htm? (accessed on 17 December 2017).

9. Dosimetría BeOSL. Available online: http://www.radmedical.com.mx/?page_id=2 (accessed on 17 December 2017).

10. Electronic Dosimeter DMC2000. Available online: https://www.dosimetry.com/images/pdf/LIT4319_EDs_ combined.pdf (accessed on 17 December 2017).

11. Pen Dosimeters. Available online: http://seintl.com/radiationalert/pen_dosimeters.html? (accessed on 17 December 2017).

12. Glenn, F.K. Radiation Detection and Measurement, 3rd ed.; John Wiley \& Sons: Hoboken, NJ, USA, 2000.

13. Ionization Chamber. Available online: https://www.orau.org/PTP/collection/ionchamber/ introionizationchamberr.htm (accessed on 17 December 2017).

14. Proportional Counter. Available online: https://www.orau.org/PTP/collection/proportional\%20counters/ introprops.htm (accessed on 17 December 2017).

15. Geiger Muller Counter. Available online: https://www.cpp.edu/ pbsiegel/bio431/texnotes/chapter4.pdf? (accessed on 17 December 2017).

16. Scintillation Detectors. Available online: http://www-physics.lbl.gov/ spieler/physics_198_notes/PDF/ III-Scint.pdf? (accessed on 17 December 2017).

17. Helmuth Spieler. Semiconductor Detector. 1998. Available online: http://www-physics.lbl.gov/ spieler/ SLAC_Lectures/PDF/Sem-Det-I.pdf (accessed on 17 December 2017).

18. Geiger Counter-Radiation Sensor Board for Arduino and Raspberry Pi. Available online: https://www.cooking-hacks.com/documentation/tutorials/geiger-counter-radiation-sensor-boardarduino-raspberry-pi-tutorial (accessed on 17 December 2017).

19. Raspberry Pi. Available online: https://www.raspberrypi.org/ (accessed on 17 December 2017).

20. Instadose 1. Available online: https://www.mirion.com/products/instadose-dosimetry-services/ (accessed on 17 December 2017).

21. Dosicard. Available online: http://www.canberra.com/products/hp_radioprotection/dosimetry.asp (accessed on 17 December 2017).

22. Poudel, S.; Weir, L.; Dowling, D.; Medich, D.C. Changes in Occupational Radiation Exposures after Incorporation of a Real-time Dosimetry System in the Interventional Radiology Suite. Health Phys. 2016, 111, S166-S171. [CrossRef] [PubMed]

23. Servoli, L.; Bissi, L.; Fabiani, S.; Magalotti, D.; Placidi, P.; Scorzoni, A.; Calandra, A.; Cicioni, R.; Chiocchini, S.; Dipilato, A.C.; et al. Personnel real time dosimetry in interventional radiology. Phys. Med. 2016, 32, 1724-1730. [CrossRef] [PubMed]

24. Nuclear Open-Source Radiation Monitoring System. Available online: https://www.blackhat.com/docs/ us-17/wednesday/us-17-Santamarta-Go-Nuclear-Breaking\%20Radition-Monitoring-Devices-wp.pdf (accessed on 17 December 2017).

25. Terasaki, K.; Toshioh, F.; Murazaki, H.; Kuramoto, T.; Umezu, Y.; Ishigaki, Y.; Matsumoto, Y. Evaluation of basic characteristics of a semiconductor detector for personal radiation dose monitoring. Radiol. Phys. Technol. 2017, 10, 189-194. [CrossRef] [PubMed]

26. Ishigaki, Y.; Matsumoto, Y.; Ichimiya, R.; Tanaka, K. Ultra-low-cost radiation monitoring system utilizing smartphone-connected sensors developed with internet community. In Proceedings of the IEEE Sensors Conference, Taipei, Taiwan, 28-31 October 2012; pp. 652-655.

27. Ishigaki, Y.; Matsumoto, Y.; Ichimiya, R.; Tanaka, K. Development of mobile radiation monitoring system utilizing smartphone and its field tests in Fukushima. IEEE Sens. J. 2013, 13, 3520-3526. [CrossRef]

28. Raspberry Pi to Arduino Shields Connection Bridge. Available online: https://www.cooking-hacks.com/ raspberry-pi-to-arduino-shield-connection-bridge (accessed on 17 December 2017). 
29. Huawei E173. Available online: https://www.amazon.es/Huawei-E173-M\%C3\%B3dem-7-2Mbps-blanco/ dp/B008BQEFYM (accessed on 17 December 2017).

30. Apache. Available online: https://www.apache.org/ (accessed on 17 December 2017).

31. PHPMyAdmin. Available online: https:/ / www.phpmyadmin.net/ (accessed on 17 December 2017).

32. Async Task-Android. Available online: https://developer.android.com/reference/android/os/AsyncTask. html (accessed on 17 December 2017).

33. Intent Class-Android. Available online: https://developer.android.com/reference/android/content/ Intent.html (accessed on 17 December 2017).

(C) 2018 by the authors. Licensee MDPI, Basel, Switzerland. This article is an open access article distributed under the terms and conditions of the Creative Commons Attribution (CC BY) license (http://creativecommons.org/licenses/by/4.0/). 


\section{Resumen}

\subsection{A Regional Solution for Patient Radiological Dose Management}

\subsection{Resumen}

Cuando una organización de salud decide optar por controlar las dosis de radiación a paciente en estudios radiológicos, ésta se debe enfrentar a diferentes retos. De entre todos, destaca el diseño, desarrollo e implantación de un sistema que, de una manera eficiente, obtenga resultados de dosis apropiados, proporcionando seguridad al paciente. En este trabajo se proponen unas "buenas prácticas" en cómo abordar este reto mediante la utilización de un software automático de gestión de dosis a paciente, compartiendo la experiencia obtenida en una región del Suroeste de España (Región de Murcia) dónde se comenzó a implantar estos sistemas en el año 2015. La metodología se basa en tres pilares fundamentales: (i) estandarización de protocolos, (ii) establecimiento de los valores de referencia de dosis (DRL) y, (iii) métodos de optimización y evaluación continua en la protección radiológica a los pacientes.

\subsection{Materiales y métodos}

Se define organización de salud como un sistema formado por diferentes hospitales, generalmente situados en una misma zona geográfica (en España, lo acotaremos a Región o Comunidad Autónoma), gestionados y coordinados por un sistema central común. La meto-

dología parte de un estado inicial donde se ha instalado un sistema de control y seguimiento de dosis radiológica y se encuentra en condiciones óptimas de funcionamiento tras al menos un mes de captura y procesado de datos. Para implantar esta metodología, el sistema de 
salud debe abordar dos escenarios bien diferenciados:

\section{Implantación a nivel hospitalario}

La metodología de implantación a nivel hospitalario está fundamentada en 3 fases que se detallan a continuación:

\section{- Gestión de Alertas:}

La generación de alertas en casos de sobreexposición de pacientes es fundamental, con objeto de detectar los casos de malas prácticas e implicar fehacientemente al personal sanitario. Para ello el sistema debe permitir derivar valores umbrales de dosis que activen estas alarmas, obteniendo una metodología ideal de medición de la actividad del servicio y de evaluación de las oportunidades de mejora. Además, la inclusión de una tarea de justificación de alertas ofrece un soporte adicional a la hora de reducir su número, siempre y cuando, esto sea posible.

\section{- Estandarización de técnicas o protocolos de los equipos:}

La estandarización de protocolos busca como objetivo principal el establecimiento de un mismo protocolo o técnica para la misma indicación clínica. Además, esta estandarización debe proporcionar el mismo patrón de referencia relativo al número de episodios o series de irradiación. De esta forma, cuando cada técnica sea comparada con un nivel de referencia de dosis, o incluso con otros hospitales, ésta se encuentre totalmente definida y acotada.

La forma de actuar sobre la estandarización de cada equipo se centra fundamentalmente en la creación de nuevos protocolos y la modificación del sistema de trabajo actual en el binomio técnico-radiólogo. Por lo general, cuando una técnica no se encuentra estandarizada, pueden deberse a dos causas principales:

- No se encuentra disponible la técnica que se precisa, y por tanto se recurre a otra. 
- b. La técnica requerida se encuentra disponible pero no se suele utilizar por no aportar los resultados que se esperan de ella

\section{- Optimización de la dosis por protocolo:}

En la fase de optimización se tratará de buscar oportunidades de mejora y reducción de la dosis radiológica para cada una de las técnicas con objeto de obtener la calidad mínima necesaria de la imagen para su posterior diagnóstico. Para ello, siempre debe tenerse en cuenta el equilibrio calidad de imagen versus dosis. Hay dos factores que afectan principalmente a la dosis irradiada durante un estudio radiológico:

- La habilidad y experiencia del técnico de rayos. En este caso es determinante la selección de los parámetros más adecuados, amplitud de estudios, colimación manual (mecanismo que permite que los rayos X apunten hacia la región deseada), etc.

- La configuración de cada técnica que se debe llevar a cabo para cada estudio en particular. Para ello en el dispositivo se debe establecer los siguiente parámetros $\mathrm{kV}, \mathrm{mA}$, pitch (relación entre el giro del tubo sobre el paciente y la velocidad de la mesa), velocidad de rotación, colimación, auto-mA (valor de corriente automática del tubo o predefinida por el técnico de rayos), etc.

Siempre que se determine que una técnica puede ser optimizada, deberá trabajarse en la modificación de estos dos factores. El papel del radiólogo es fundamental durante este proceso dado que debe aportar siempre su opinión sobre la imagen final, determinando si es diagnóstica o no.

Independientemente de estas tres fases, otro aspecto a tener en cuenta es la que está relacionada con la comunicación dentro del propio hospital ya que la protección radiológica al paciente comienza mucho antes de realizar el estudio radiológico, por tanto, existen diferentes procesos que son necesarios abordar antes, durante y después de implantar estos sistemas: 


\section{- Presentación del sistema y la metodología a todo el personal implicado:}

Reunión de Kick-off de lanzamiento del sistema donde se comentará al personal sanitario los motivos relativos a la implantación de estos sistemas dentro de la organización, motivándolos sobre la seguridad del paciente. Es de suma importancia realizar un análisis de la actividad del propio hospital, mostrando prácticas actuales, alertas generadas y como se encuentran los niveles de dosis medidos en pacientes respecto a los niveles de referencia o DRL. En esta misma reunión se pueden establecer los primeros pasos en la gestión de dosis y crear un plan de acción dependiendo de las carencias que se aprecien en el análisis de actividad.

\section{- Creación de un Equipo de Dosis:}

Se requiere la creación de un equipo dosis multidisciplinar con el objetivo de liderar la implantación de la nueva metodología. Se pretende que los miembros de este equipo sean figuras representativas, influyentes, con capacidad de liderazgo y autoridad dentro del servicio de radiología. De esta forma se facilitará el cambio a un nuevo sistema de dosimetría.

Para ello, dentro del equipo de dosis, debe existir un miembro especialista de cada disciplina: responsable de protección radiológica, radiólogos de referencia, técnico de rayos, Enfermeros, jefe de servicio y supervisor, entre otros.

\section{- Formación del personal:}

Todo el personal, comenzando con el equipo de dosis, debe conocer de primera mano la herramienta de gestión y tener nociones básicas sobre radiaciones ionizantes. El perfil o disciplina de cada miembro será determinante para la formación que deberá recibir:

- Protección radiológica: Seguimiento de los exámenes, creación de umbrales de alerta, visualización de los parámetros dosimétricos y de adquisición de cada paciente, análisis detallados de los diferentes índices de dosis, historial dosimétrico 
del paciente, etc.

- Radiólogos: Visualización de alertas, parámetros dosimétricos, análisis cuantitativos de los protocolos y descripciones de estudio más utilizados, historial dosimétrico del paciente, etc.

- Técnicos: Visualización y justificación de alertas, visualización de pacientes, historial dosimétrico, etc.

\section{- Gestión de alertas:}

Siempre van a existir alertas en el sistema, pero es importante dar una justificación a cada una de ellas. De esta forma, y dependiendo de su origen, será posible actuar sobre las mismas para así reducir su número de forma considerable. A modo de ejemplo, serán inevitables los casos de alertas por un incremento temporal de un estudio a petición del radiólogo o alertas motivadas por un mal centraje de los pacientes, o incluso aquellas que se generan por pacientes no colaboradores.

\section{- Reuniones de seguimiento del comité de dosis:}

Estas reuniones permitirán hacer una monitorización de las alertas surgidas, proporcionando soluciones por consenso. Además, se llevarán a cabo análisis de estandarización y optimización; el objetivo es encontrar soluciones en los casos donde se prevea un margen de mejora.

\subsubsection{Implantación a nivel corporativo}

La implantación a un nivel superior, más corporativo, está basada en determinar qué situación posee cada centro que la compone, una estandarización de las prácticas (metodología) realizadas en toda la organización y la creación de un comité evaluador de la implantación. Veamos en detalle cada uno de los aspectos mencionados:

\section{- Comparación/benchmarking entre hospitales:}


La comparación de las prácticas y niveles de referencia de dosis entre hospitales es fundamental para lograr que toda la organización consiga alinearse en la búsqueda de un sistema estándar regional.

\section{- Creación de una lista estándar de prácticas:}

Existe una dificultad adicional que entraña la instauración de las mismas prácticas en todos los hospitales dadas las diferencias en cuanto a tecnología, formación del personal, flujo de trabajo, etc. Por ello, una solución es la creación de una lista estándar de técnicas o prácticas. De esta forma y mediante consenso, se puede obtener un listado de prácticas comunes necesarias en cualquier hospital, junto con valores estándar, indicaciones clínicas y valores de referencia para cada una de ellas. De esta forma, cada hospital podrá vincular (mapear) cada uno de sus protocolos con los de esta lista, obteniendo directamente unos indicadores de estandarización y hacia dónde dirigir la optimización.

\section{- Creación de un comité regional de dirección:}

Las directrices y recomendaciones generales deben marcarse en este comité, el cual debe estar formado por personal directivo de los hospitales involucrados, generalmente, jefes de servicio, jefes de protección radiológica y personal de administración e informática.

\subsection{Conclusiones}

La protección radiológica del paciente en los estudios clínicos realizados pasa por la implantación de un mecanismo de control y mejora continua. Los nuevos sistemas corporativos de gestión de dosis están dirigidos en este sentido, contribuyendo, por una parte, a concienciar y establecer mecanismos de gestión de dosis, y, por otra, a proveer de un sistema para que el paciente reciba la dosis mínima requerida para su diagnóstico independientemente del centro al que acuda dentro de la organización donde se implante. 


\subsection{Computed Tomography Radiation Dose in a Regional Survey}

\subsection{Resumen}

Este trabajo contribuye al establecimiento de los niveles de referencia en la modalidad de TAC para 5 equipos de diferentes fabricantes ubicados dentro de una misma área de salud. Con objeto de un estudio detallado de las dosis recibidas se ha utilizado un software automático de gestión de dosis implantado en un sistema público ubicado en una región al Suroeste de España (Región de Murcia). Se han evaluado dos parámetros de medida de dosis: CTDIvol y DLP para los tres protocolos más utilizados en la modalidad de TAC que comprenden tres regiones anatómicas distintas: (i) Cabeza, (ii) Torax, y (iii) AbdomenPelvis. El resultado mostró diferencias de dosis irradiada a paciente cercanas al $30 \%$ en alguno de los protocolos estudiados dependiendo del equipo TAC dónde se haya realizado el estudio.

\subsection{Materiales y métodos}

Los equipos de TAC del estudio fueron conectados al sistema corporativo de gestión de dosis implantado en esta región desde el año 2015 mediante el envío de los datos a través del protocolo estándar de transmisión de imágenes médicas (DICOM).

\subsubsection{Recolección de datos}

Durante 3 meses consecutivos se han recopilado los estudios de TAC, todos ellos de tecnología helicoidal, de 5 equipos pertenecientes a tres hospitales públicos dependientes de la misma área de salud. Estos equipos pertenecían a dos fabricantes distintos, en este caso, Siemens y GE Healthcare. Además, existen claras diferencias tecnológicas, destacando el número de detectores (cortes) que realiza por cada giro el tubo, variando en el rango de 16 a los 12 cortes.

Las tres zonas anatómicas seleccionadas han sido Cabeza, Tórax y Abdomen-Pelvis, debido a que, entre las tres abarcan más del $80 \%$ de todos los estudios que se realizan en la 
modalidad de TAC. En detalle, para cada uno de los protocolos evaluados, se ha evaluado un importante número de estudios, que es el siguiente:

- Protocolo de cabeza: 1445 estudios

- Protocolo de Tórax: 579 estudios

- Protocolo de Abdomen-Pelvis: 1055 estudios.

\subsubsection{Análisis de datos}

Una vez finalizado el estudio se recopilaron los datos de dosis personalizados de cada paciente además de los diferentes parámetros técnicos utilizados en el estudio. Estos son las siguientes:

\section{- Longitud de escaneo ( $\mathrm{mm})$ :}

Parámetro utilizado para delimitar la zona anatómica sobre la que se va a realizar el estudio.

\section{- Kilovoltaje $(\mathrm{kV})$ :}

Parámetro que mide el voltaje utilizado en el tubo de Rayos X.

\section{- Corriente del tubo (mA):}

Corriente eléctrica proporcionada al tubo para el estudio.

\section{- Factor pitch:}

Indica la velocidad de la mesa donde está ubicado el paciente que está siendo irradiado.

La Figura 5.1 muestra qué parámetros técnicos afectan al valor de las métricas CTDIvol y DLP y, por consiguiente, a la radiación absorbida por el paciente.

Como se puede apreciar en la figura anterior, dependiendo de la configuración de estos parámetros antes del estudio de TAC, se obtiene un valor de CTDIvol y DLP. Estas métricas fueron utilizadas posteriormente para establecer los valores de referencia de cada protocolo. 


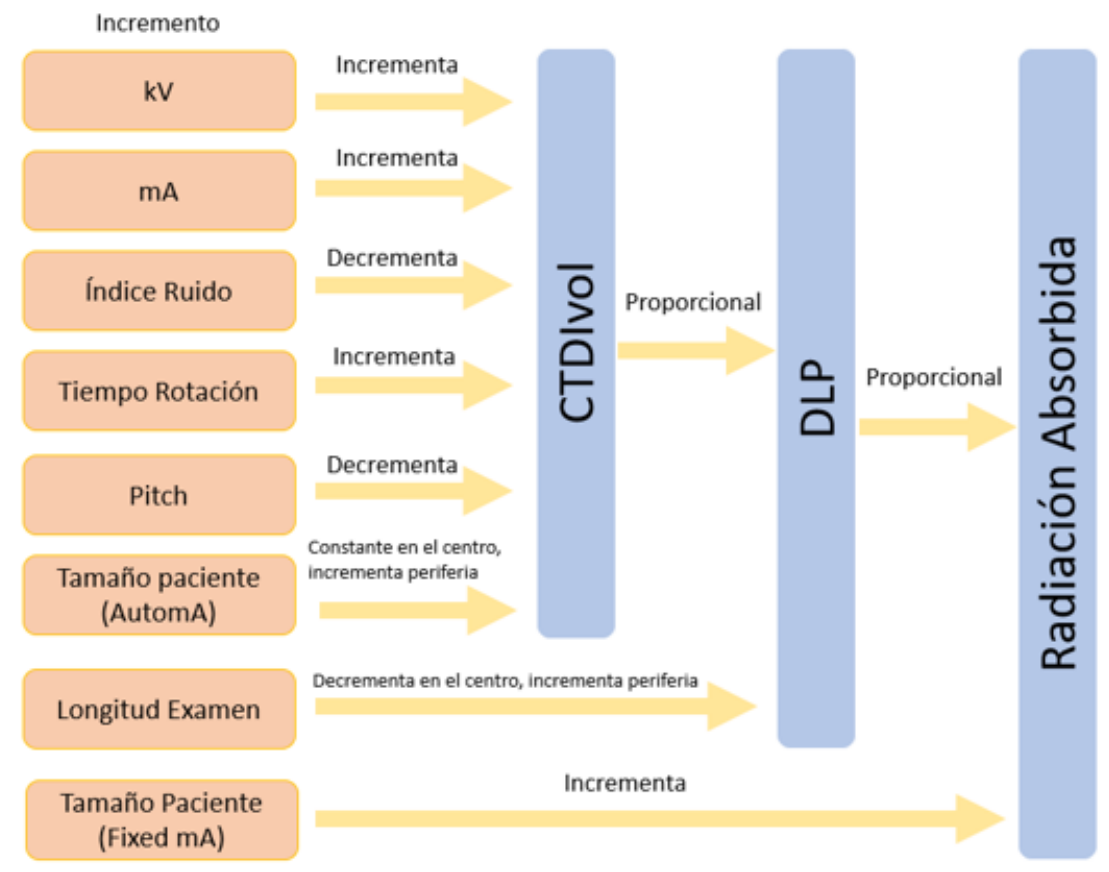

Figura 5.1: Valores que afectan a la dosis emitida en la modalidad de TC

Además, se realizó un estudio de la distribución estadística de estos dos valores de CTDIvol y DLP; ambas métricas seguían una distribución log-normal.

\subsubsection{Establecimiento de los valores de referencia DRL}

Para cada equipo de TAC y protocolo empleado se calcula la mediana de la distribución de CTDIvol y DLP. Este valor constituye el nivel de referencia de dosis local, el llamado DRL local. Para cada protocolo, se calcula el DRL regional como tercer cuartil de la de la distribución de DRL locales de todos los TAC. 


\subsection{Resultados y contribución}

En la Tabla 5.1 muestra los resultados alcanzados por este estudio. En particular, la tabla detalla los rangos en los que se distribuyen los parámetros de dosis CTDIvol y DLP.

\begin{tabular}{|c|c|c|}
\hline Protocolo & Rango mediana CTDIvol (mGy) & Rango mediana DLP $(\mathrm{mGy} \cdot \mathrm{cm})$ \\
\hline Cabeza & $33.0-63.8$ & $527-1162$ \\
\hline Tórax & $6.7-9.7$ & $218-334$ \\
\hline Abdomen-Pelvis & $10.0-12.1$ & $383-453$ \\
\hline
\end{tabular}

Tabla 5.1: Valores (rango de medianas) en las métricas de interés de CTDIvol y DLP

Las diferencias en la técnica utilizada en distintos equipos del mismo modelo y fabricante para el protocolo de Tórax han supuesto diferencias de hasta el $30 \%$ en la dosis irradiada al paciente. Este hecho ha propiciado que se realicen tareas de optimización, previendo reducir en cerca de un $20 \%$ en aquellos casos donde los valores de radiación son más altos.

La capacidad de registro de, además de la dosis irradiada, los parámetros técnicos del estudio hacen que el proceso de optimización de la técnica sea un proceso menos tedioso siempre y cuando se mantenga la calidad diagnóstica de la imagen.

\subsection{Conclusiones}

En el pasado, los valores de referencia eran establecidos con muy pocos datos y sobre pacientes tipificados en cuanto a peso, altura y complexión, lo cual los hacía muy imprecisos. Gracias a los nuevos sistemas de control de dosis, carece de sentido elegir cuidadosamente el tamaño de muestra de pacientes, pudiendo obtener valores de referencia a partir de toda la población. Además, esta forma de trabajar también implica que existan numerosos datos denotados como anómalos (outliers), por lo tanto, su eliminación es requerida para establecer valores de referencia adecuados en los diferentes protocolos estudiados.

Finalmente, el uso de estos sistemas de control en una organización se convierte en una herramienta indispensable para la optimización de los valores de referencia de dosis. 


\subsection{Optimization of CT protocols using cause-and-effect analysis of outliers}

\subsection{Resumen}

El objetivo de este estudio fue implementar una metodología de identificación y análisis de valores atípicos que permitiese optimizar los protocolos de exploración en la modalidad de TAC. Se particularizó a datos obtenidos de los TAC en cabeza, en particular, los parámetros técnicos y los valores de dosis, que fueron almacenados en una base de datos de forma automática dentro del sistema corporativo de gestión de dosis. La distribución de las métricas de dosis de referencia (DRL) se obtuvo a lo largo de un período de 1 año. Los umbrales para la obtención de los datos atípicos (outliers) se calcularon i) teniendo en cuenta la forma específica de la distribución, y ii) considerando un mecanismo sólido de medida de la asimetría; el parámetro llamado "medcouple" (MC). Posteriormente, los outliers pertenecientes a 4 meses fueron identificados por un comité de dosis multidisciplinar para realizar un análisis de causa-efecto.

Los valores de referencia de las dosis se obtuvieron a partir de 3690 exámenes de TAC de cabeza. Tanto los valores de CTDIvol como DLP mostraron un cierto grado de asimetría, con un valor de medcouple de 0.05 y 0.11 , respectivamente. Todos los outliers superiores fueron agrupados en 3 grupos en relación a sus causas: (i) selección inadecuada del protocolo, (ii) brazos u objetos en el campo de visión, y (iii) diámetro anormal de la región de exploración. En cuanto a los outliers inferiores, el $90 \%$ se atribuyó a la inclusión de secuencias de examen adicionales en el protocolo original de la cabeza y que han propiciado que se realiza el examen de alguna parte anatómica adicional durante el estudio. El restante $10 \%$ por causas desconocidas. Finalmente, también se elaboró un diagrama general de causa-efecto para los valores atípicos. 
Mientras que el método general de obtención de valores de referencia en la modalidad de TAC ayuda a realizar comparaciones con otros centros, el método de análisis de outliers representa un paso más en los procesos de optimización de las técnicas relacionadas con los protocolos de exploración TAC. El método propuesto se centra en el uso y manejo incorrecto del instrumental TAC, que está relacionado principalmente por el desconocimiento de la tecnología que tienen los especialistas que realizan este tipo de pruebas.

\subsection{Materiales y métodos}

\subsubsection{Recopilación de datos}

El estudio se centra en el protocolo más solicitado por los equipos médicos, el Cabeza rutina Helicoidal sin contraste. Para ello se utilizó un TAC de la compañía Siemens que posee 128 cortes.

Los estudios fueron llevados a cabo en el año 2017, analizando un total de 3690 exámenes, y obteniendo medidas y valores para las siguientes métricas: CTDIvol, DLP, miliamperaje efectivo y longitud del estudio.

\subsubsection{Identificación de outliers y análisis}

La identificación de outliers se llevó a cabo mediante el procedimiento de cajas y bigotes modificado desarrollado por Vanderbiere [1], y ampliamente utilizado cuando la distribución de datos es asimétrica. Además, si se introduce en este procedimiento el parámetro MC se consigue modificar los umbrales de identificación de outliers. Este parámetro MC varía entre -1 y 1 siendo el 0 el valor que identifica que la distribución de datos es simétrica.

Siguiendo el método estadístico ideado por Vanderbiere, se definen los nuevos umbrales de outliers para las métricas CTDIvol y DLP y mostrados en la Figura 5.2. Estos nuevos umbrales de outliers son representado en línea punto y raya y son comparados con los límites tradicionales mostrados en línea punteada. 

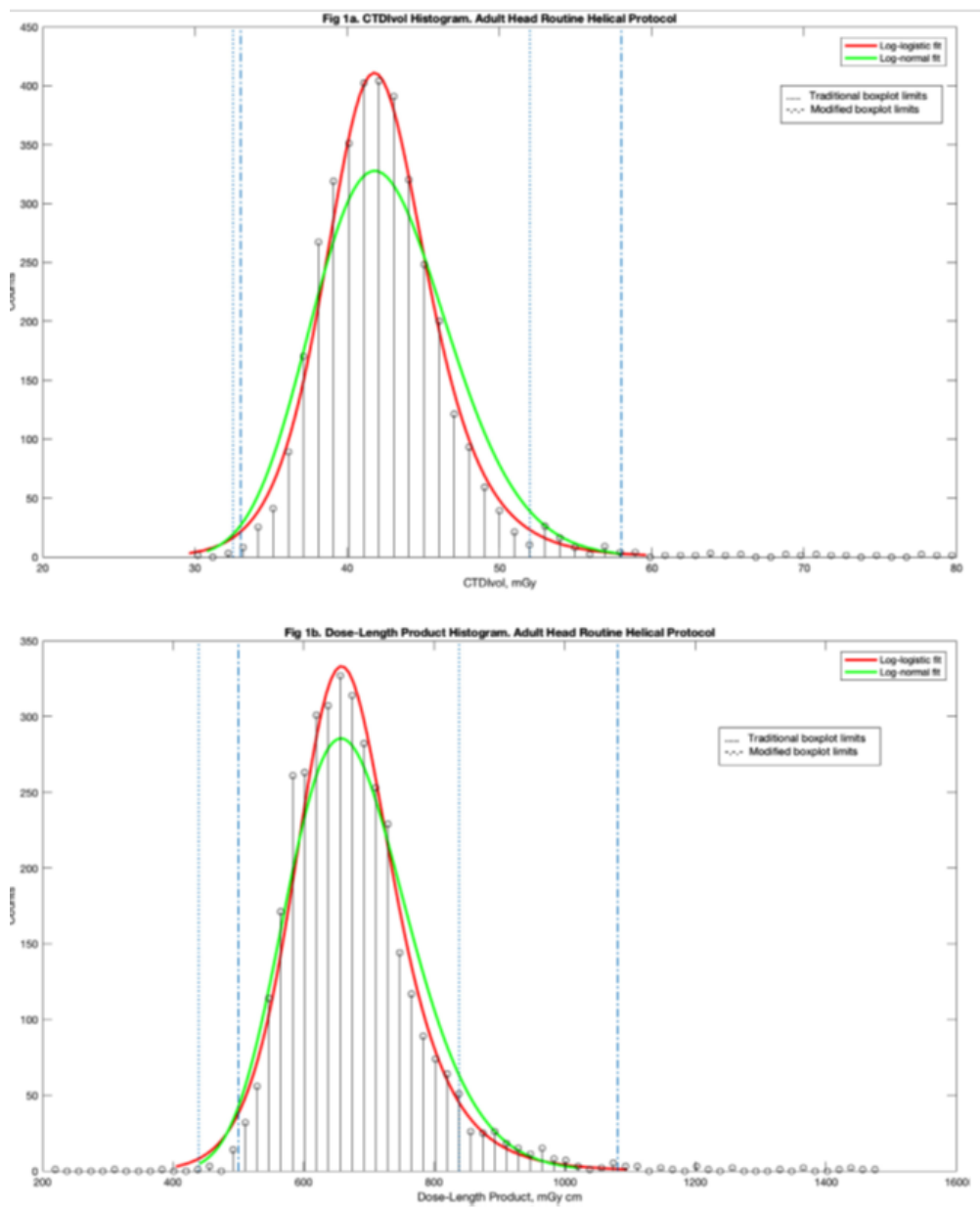

Figura 5.2: Nuevos umbrales para identificación de outliers referidos a CTDIvol (arriba) y a DLP (abajo)

\subsection{Resultados y discusión}

Los valores de DRL obetenidos para el CTDIvol y DLP fueron 43mGy y $664 \mathrm{mGy} \cdot \mathrm{cm}$ respectivamente, consiguiendo reducir hasta en un $15 \%$ y $45 \%$ respectivamente los valores alcanzados en el resto de los países europeos (cabe señalar que los valores de DRL españoles aún no se han establecido).

Para el análisis de los outliers se ha seleccionado una muestra de 1251 estudios de Cabeza desarrollados durante 4 meses de manera consecutiva. En esta muestra se han detectado un $5 \%$, es decir, 64 que pertenecen al grupo de outliers tanto inferiores como superiores. 
Para los outliers superiores se han identificado tres causas fundamentales:

- Selección inadecuada de protocolo:

El $65 \%$ de las veces ha sido mal seleccionado el protocolo bajo estudio, realizando incluso exámenes que se han iniciado en la cabeza y han finalizado en el tórax superior, como se ilustra en la Figura 5.3.

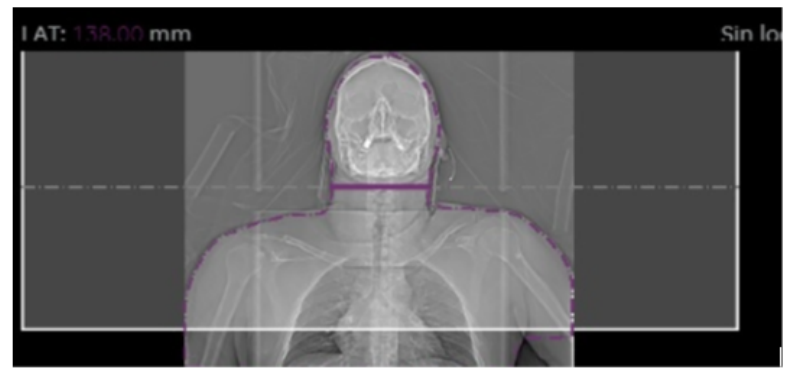

Figura 5.3: Selección inadecuada de protocolo

\section{- Brazos u objetos en el campo de visión:}

En este caso, el valor de las anomalías corresponde al $20 \%$, como puede observarse en la Figura 5.4.

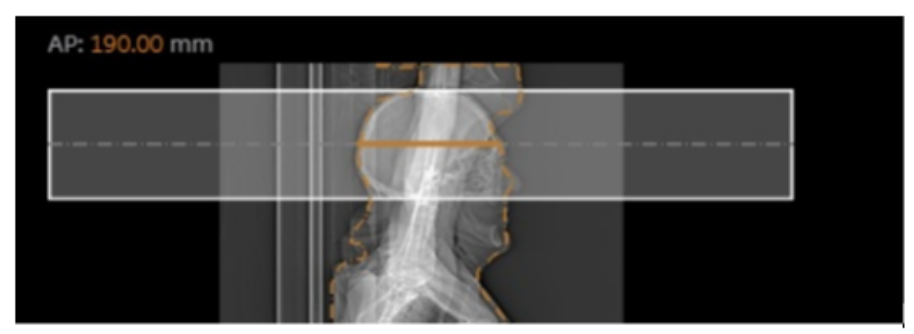

Figura 5.4: Brazo del paciente en el campo de visión del estudio de cabeza

- Diámetro de escáner no seleccionado correctamente:

Corresponde al $15 \%$ de las veces derivado del mal posicionamiento en el que se encuentra el paciente o pacientes con cuellos muy pequeños como se muestra en la Figura 5.5 . 


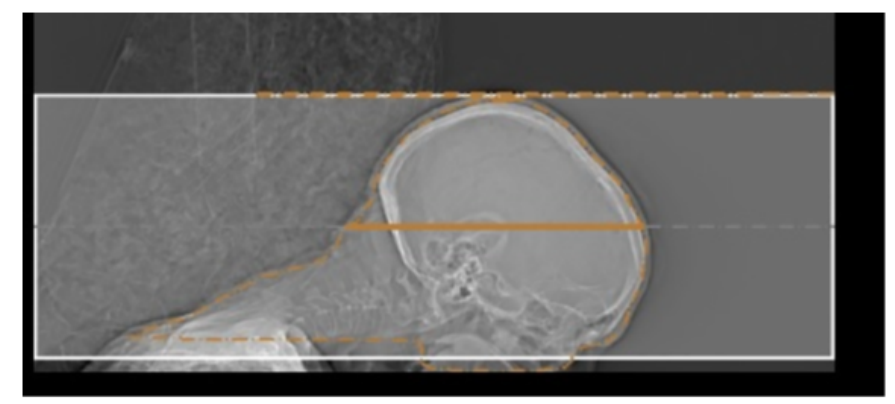

Figura 5.5: Selección errónea en el protocolo de cabeza

Los outliers inferiores se deben, en el $90 \%$ de los casos, en la adición de nuevas series de estudio con objeto de examinar otras partes del cuerpo, pero asociados al mismo examen (en nuestro caso Cabeza). Una vez finalizado el mismo, el propio sistema de registro de dosis ha calculado la dosis de CTDIvol en referencia al protocolo de Cabeza, por tanto, se computa esta métrica referida al fantoma de $16 \mathrm{~cm}$ en vez de $32 \mathrm{~cm}$, que es el que corresponde al resto del cuerpo, lo que resulta en una dosis mucho menor.

A continuación, se realiza una breve descripción de estos 4 agentes causantes de la aparición de outliers:

\section{- Profesionales:}

El avance tecnológico en el equipamiento TAC especialmente en la determinación automática de valores en parámetros como el Kilovoltaje y la modulación de corriente de tubo previos al estudio hacen que el técnico encargado de la exploración no esté completamente familiarizado con la tecnología, en particular, en pacientes que no se adecuan al estándar del protocolo seleccionado. Adicionalmente, otra de las causas de posibles errores humanos está en la selección del tipo de protocolo para un tipo específico estudio.

\section{- Equipo:}

Tres diferentes causas pueden ser el origen de la aparición de outliers; el propio sistema TAC, los inyectores de contraste y la forma en que el software de gestión de dosis 
lleva a cabo el almacenaje del estudio asignando series o valores de dosis que no se corresponden con el protocolo seleccionado

\section{- Organización del servicio:}

La falta de aprendizaje continuo del personal sanitario, así como las típicas rotaciones que se producen en el ámbito laboral, hace que, a veces, puedan surgir distracciones o falta de instrucción por parte de determinados profesionales.

\section{- Relativos al paciente:}

Un alto índice de masa corporal (IMC) puede ser la causa de la aparición de outliers, aunque en el caso particular de la cabeza, este hecho juega un papel menos destacable. El posicionamiento, elementos metálicos o incluso pacientes que no colaboran en la prueba son las principales causas del incremento de dosis, y por consiguiente de la aparición de estos outliers.

En la Figura 5.6 se resumen los diferentes agentes mediante un diagrama de Causa y Efecto.

\subsection{Conclusiones}

Detectar y analizar outliers juega un papel importante en el proceso de optimización de protocolos, y es totalmente complementaria a la metodología de obtención de resultados en métricas como DRL. La forma específica de la distribución de valores de dosis es considerada a la hora de establecer los umbrales (tanto superior como inferior) de detección de outliers. El diagrama causa-efecto proporciona, por una parte, un valor añadido en la evaluación de estos valores atípicos de la distribución y, por otra, un punto de partida en la mejora de los procesos internos sanitarios, que revertirán en beneficio del paciente. 


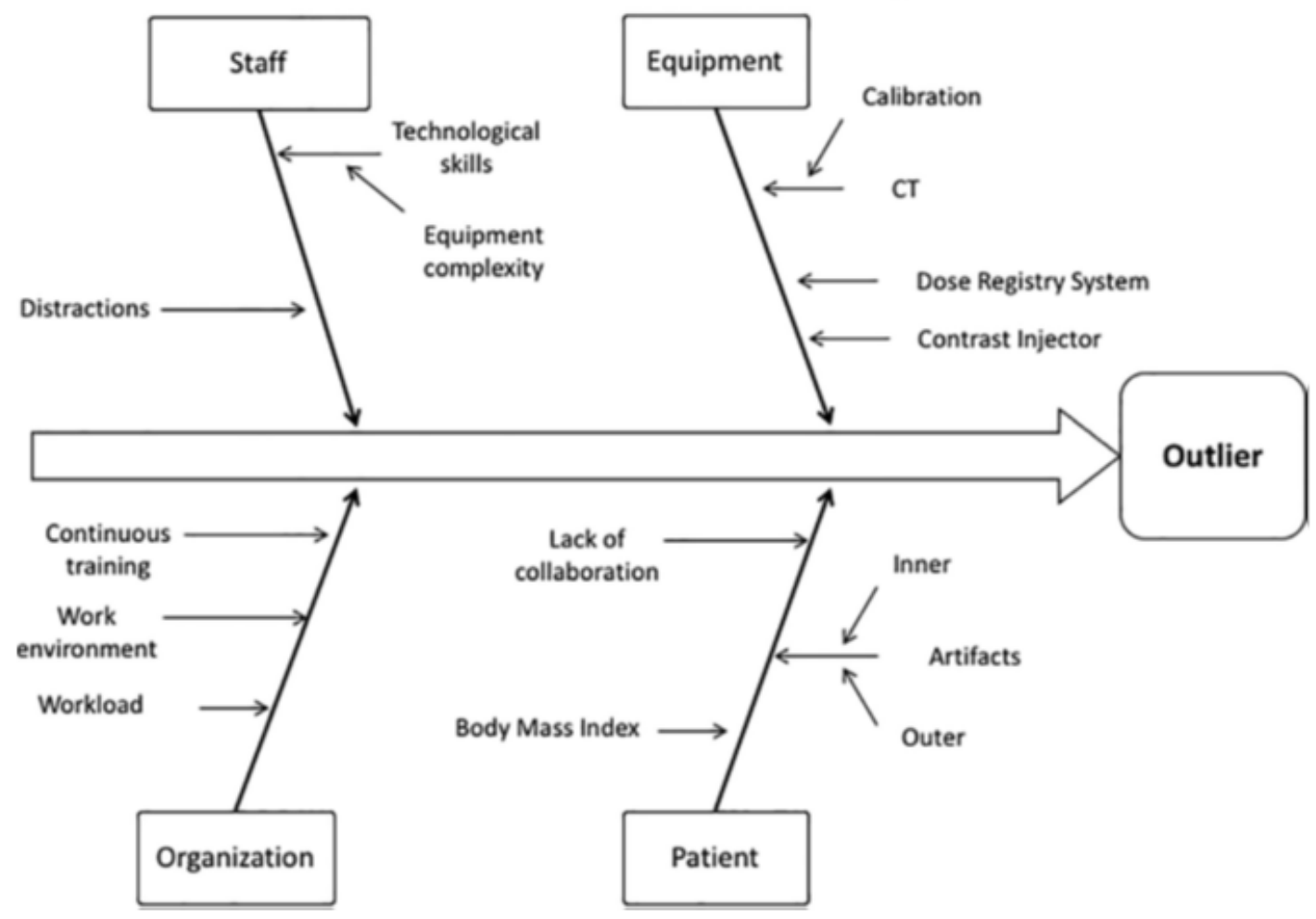

Figura 5.6: Diagrama de causa y efecto 


\subsection{Ionizing Radiation Measurement Solution in a Hospital Environment}

\subsection{Resumen}

La radiación ionizante es uno de los mayores riesgos que afectan a los profesionales sanitarios y a los pacientes en todo el mundo. Para medir estos valores se utilizan medidores de dosis de área en las zonas con riesgo de radiación, así como dosímetros personales llevados "in situ" por los profesionales sanitarios. Sin embargo, existen desventajas de estos sistemas de medición en cuanto a coste, precisión en la detección, procesamiento de datos en tiempo real, flexibilidad etc.; en este sentido, un estudio exhaustivo ha sido detallado en este artículo. Para paliar estas debilidades, se ha desarrollado un sistema portable, de código abierto y de bajo coste consistente en un detector comercial Geiger-Müller (GM) que captura la dosis recibida y la envía a una base de datos remota. Esto permite al personal médico visualizar de primera mano las dosis acumuladas, así como otros estadísticos relacionados a través de una aplicación móvil. Finalmente, el dispositivo ha sido validado en un centro nacional de calibración con el objetivo de, posteriormente, llevar a cabo las pruebas piloto en entorno hospitalario.

\subsection{Materiales y métodos}

\subsubsection{Sistema planteado}

El dispositivo creado es un medidor de radiación ionizante alfa, beta y gamma que proporciona una lectura de las radiaciones en tiempo real almacenándolas en un servidor remoto (y local) para su posterior procesado. Se ha creado además una aplicación móvil multiusuario bajo la plataforma Android que, mediante la conexión al servidor, proporciona la información al usuario en tiempo real y permite visualizar varios parámetros estadísticos de las medidas realizadas.

En la Figura 5.7 se muestra un esquema ilustrativo de la solución aportada en este trabajo. 


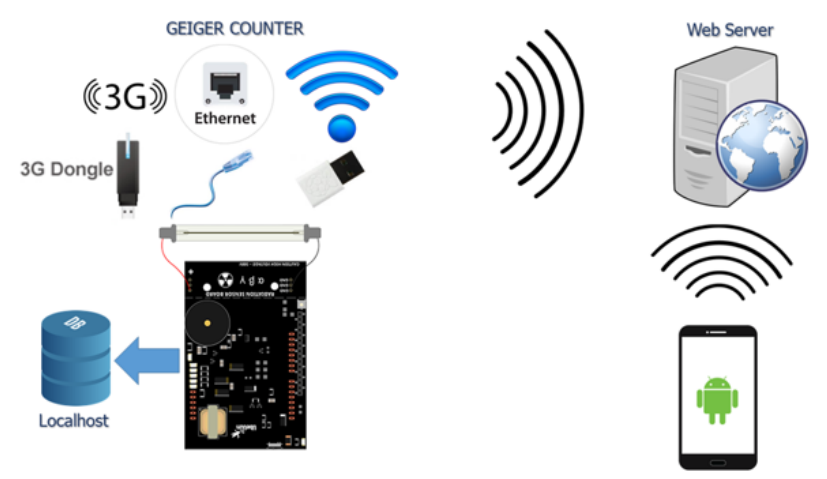

Figura 5.7: Diagrama de la solución planteada

\subsubsection{Elementos del sistema}

El sistema de medición de radiación ionizante aquí propuesto representa un paso adelante en i) la búsqueda de soluciones realistas a los problemas que emergen de los medidores actuales, y ii) la integración con los nuevos sistemas de gestión de dosis corporativos. El objetivo es ofrecer una solución completa de control de radiación a los profesionales sanitarios y su entorno. Otra aportación fundamental de este trabajo es que nuestro sistema de medición puede utilizarse tanto como dosímetro personal como dosímetro de área.

En la Figura 5.8 se ilustra el prototipo del dispositivo diseñado y desarrollado para este trabajo.

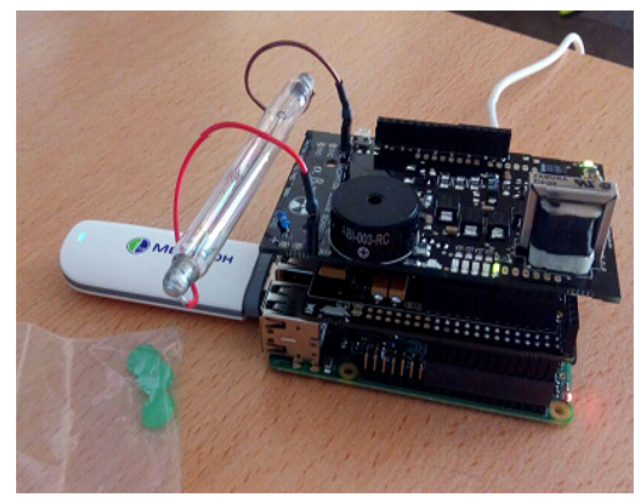

Figura 5.8: Sistema propuesto 
El dispositivo está formado por los siguientes elementos:

- Una Raspberry Pi (Figura 5.9):

encargada de procesar diferentes parámetros estadísticos de radiación, así como albergar la base de datos de respaldo.

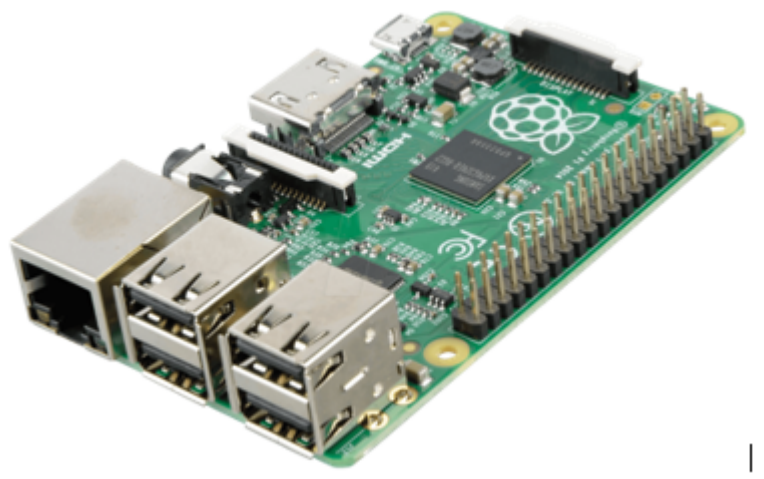

Figura 5.9: Raspberry Pi v2

- Tarjeta del sensor de radiación Geiger (Figura 5.10):

compuesta por el tubo Geiger-Müller (GM) y una pantalla LED que proporciona los valores de radiación medidos por el tubo GM. Esta tarjeta está dividida en dos módulos bien diferenciados:

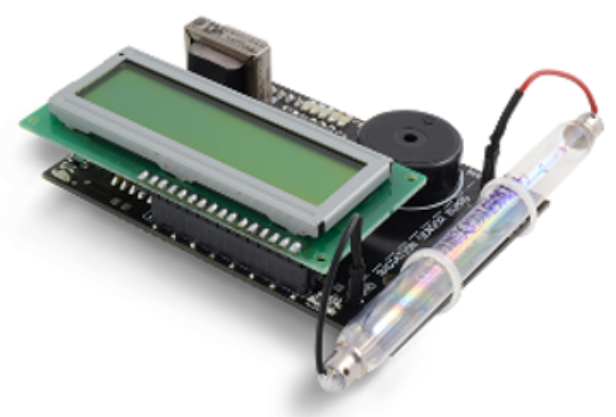

Figura 5.10: Tubo GM comercial conectado al dispositivo 
- o Módulo hardware de la fuente de alimentación. Para el correcto funcionamiento del tubo es necesario proporcionarle una diferencia de potencial que oscila entre 400 y $800 \mathrm{~V}$, obtenidos mediante un oscilador conectado a un multiplicador de voltaje compuesto por diodos, transistores, resistencias y condensadores.

- o Módulo hardware de conversión de señal. Su funcionalidad es convertir la señal analógica que genera en su salida el tubo a una señal digital para que la Raspberry sea capaz de procesar los datos.

\section{- Puente de interconexión (Figura 5.11):}

entre el detector GM y la raspberry Pi encargado de interconectar el medidor con el equipo de procesamiento de datos.

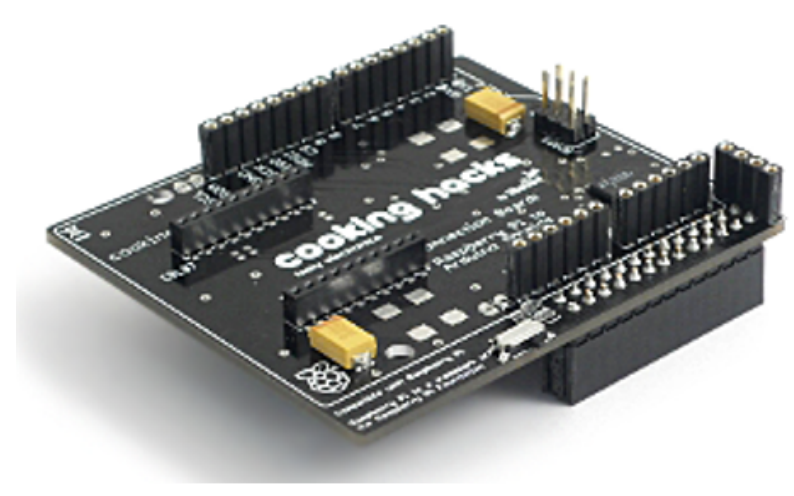

Figura 5.11: Módulo de interconexión

- Elemento externo de conectividad 3G/4G y WiFi (Figura 5.12):

que proporciona al dispositivo conectividad inalámbrica para su interconexión con el servidor de que contiene la base de datos de radiación. 


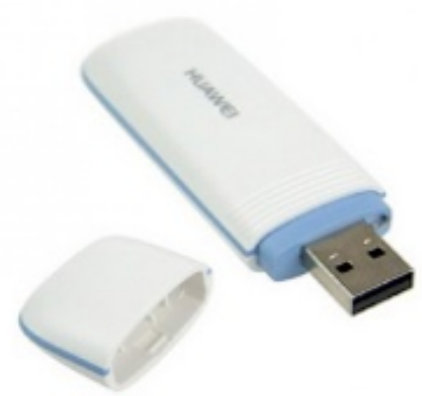

Figura 5.12: Módulo de interconexión

\subsubsection{Funcionamiento}

En primer lugar, se debe ejecutar el servidor de almacenaje de los datos de radiación; éste puede estar alojado en cualquier lugar ya que no necesita conectarse mediante ningún cable al dispositivo, es decir, puede estar ubicado en una zona geográfica diferente al dispositivo y conectarse al servidor remotamente.

En segundo lugar, se conecta la Raspberry a los $5 \mathrm{~V}$ que requiere para funcionar, seguidamente, se realizan las tareas de conexión con el servidor y comienza a realizar las mediciones en bucle hasta que el dispositivo cesa de medir cuando se le desconecte de la fuente de alimentación.

Los valores de radiación son capturados por el contador Geiger-Müller que monitoriza el número de pulsos que recibe por minuto (CPM), valor que multiplicado por un factor de conversión (K) convierte los CPM en un valor de energía. Este factor de conversión viene dado por el fabricante del tubo en sus especificaciones.

Una vez conectados tanto el servidor como el dispositivo, cada usuario (personal médico) inicia la aplicación móvil en cualquier dispositivo compatible con la plataforma Android con objeto de recibir los valores de radiación medidos. 
En la Figura 5.13 se muestra el esquema del funcionamiento del sistema.

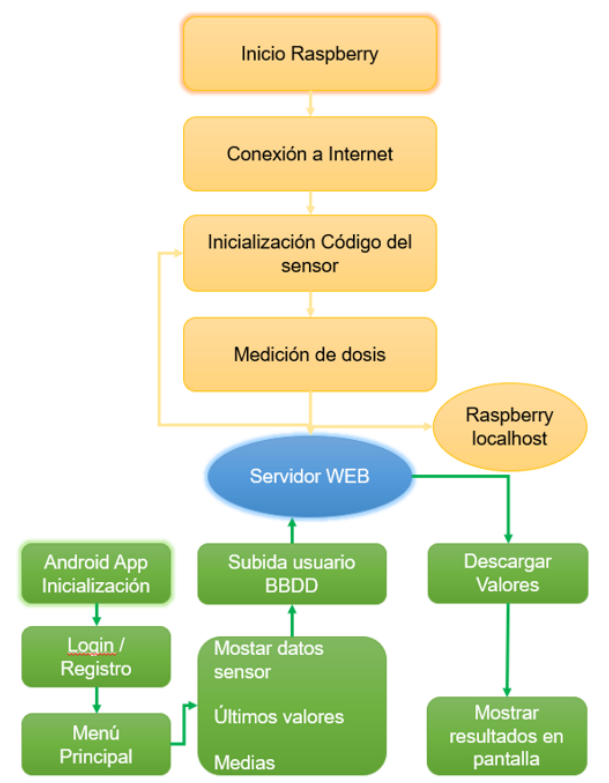

Figura 5.13: Diagrama de funcionamiento de la solución propuesta

Dado que el dispositivo puede utilizarse como dosímetro personal o medidor de área, una pantalla de "login" es mostrada al inicio de la aplicación dónde se asociarán los datos medidos de radiación al usuario logueado. Posteriormente, se mostrarán los datos en tiempo real que está midiendo el sensor así como una serie de opciones que nos permitirán conocer, entre otros valores, la media de radiación diaria, semanal, anual, hora, fecha, etc. 
En la Figura 5.14 se ilustra una serie de capturas de pantalla de esta aplicación móvil.
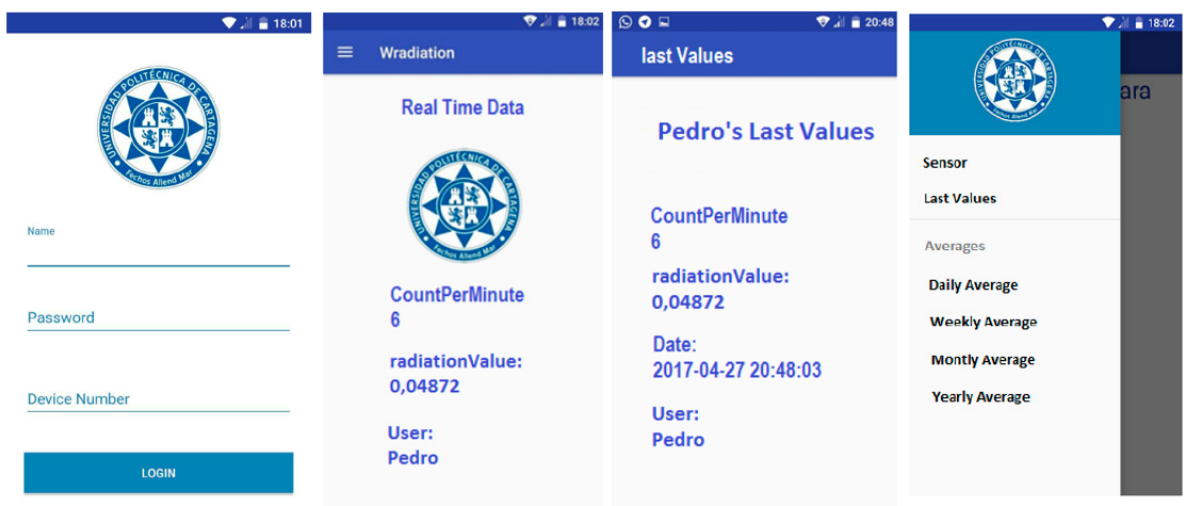

Figura 5.14: Capturas de pantalla de la aplicación de smartphone

\subsubsection{Calibración}

En relación a garantizar la fiabilidad y trazabilidad de las medidas de radiación del dispositivo, se llevó a cabo una calibración completa en el Centro Nacional de Dosimetría (CND) autorizado por el Consejo de Seguridad Nuclear y certificado por la Agencia Nacional de Acreditación (ENAC) que permite realizar calibraciones en radiaciones ionizantes y radioactividad. En la figura 5.15 se muestra el proceso de calibración en el CND.

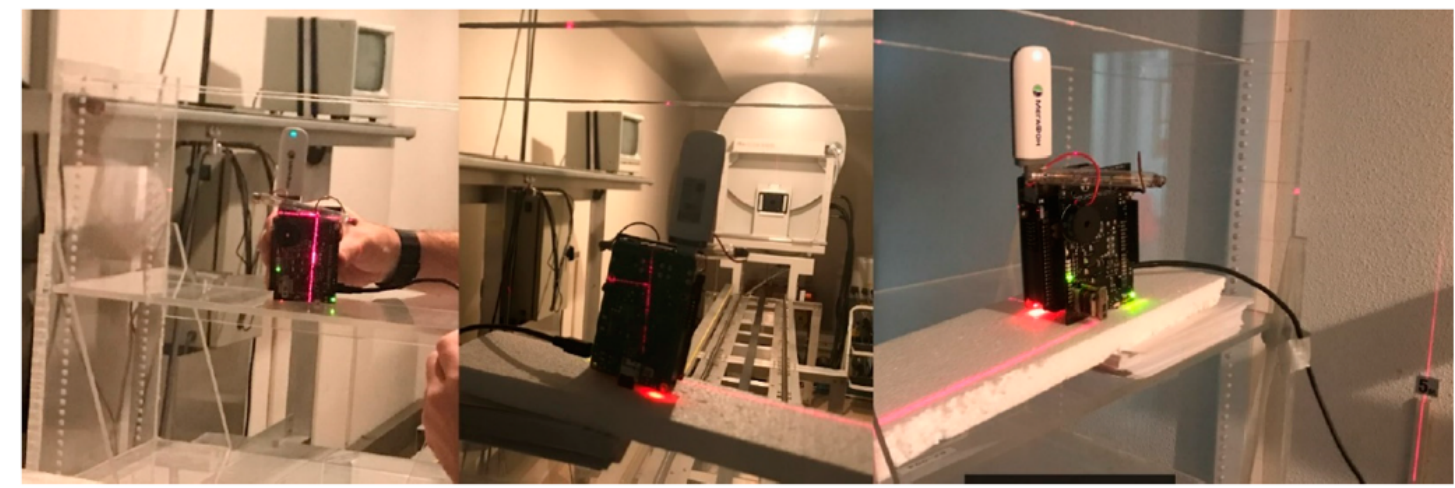

Figura 5.15: Proceso de calibración del dispositivo en el CND

Se realizaron tres tipos diferentes de calibraciones con objeto de observar la respuesta del dispositivo a diferentes calidades de medición, obteniendo como resultado una caracteri- 
zación del dispositivo para cada una de ellas y el factor corrector que se debía aplicar a las dosis medidas por el sensor Geiger-Müller del prototipo. Este factor corrector contribuyó a realizar los cálculos necesarios en la aplicación móvil para su posterior testeo en campo.

\subsection{Resultados}

El sistema propuesto fue testeado en un hospital público universitario, en concreto, en el Hospital Santa Lucía de la ciudad de Cartagena en dos ubicaciones distintas para evaluar el funcionamiento del mismo tanto como dosímetro personal y de área.

\section{- Como dosímetro de área:}

se colocó en el pasillo del departamento de medicina nuclear muy cerca de la sala del equipo PET (Positron Emission Tomography) y colocado debajo de un medidor dosímetro de área adquirido por el centro hospitalario y adecuadamente calibrado. Este medidor permitirá validar las medidas de nuestro dispositivo. La ubicación del dispositivo, así como los resultados se muestran en la Figura 5.16 y Figura 5.17.

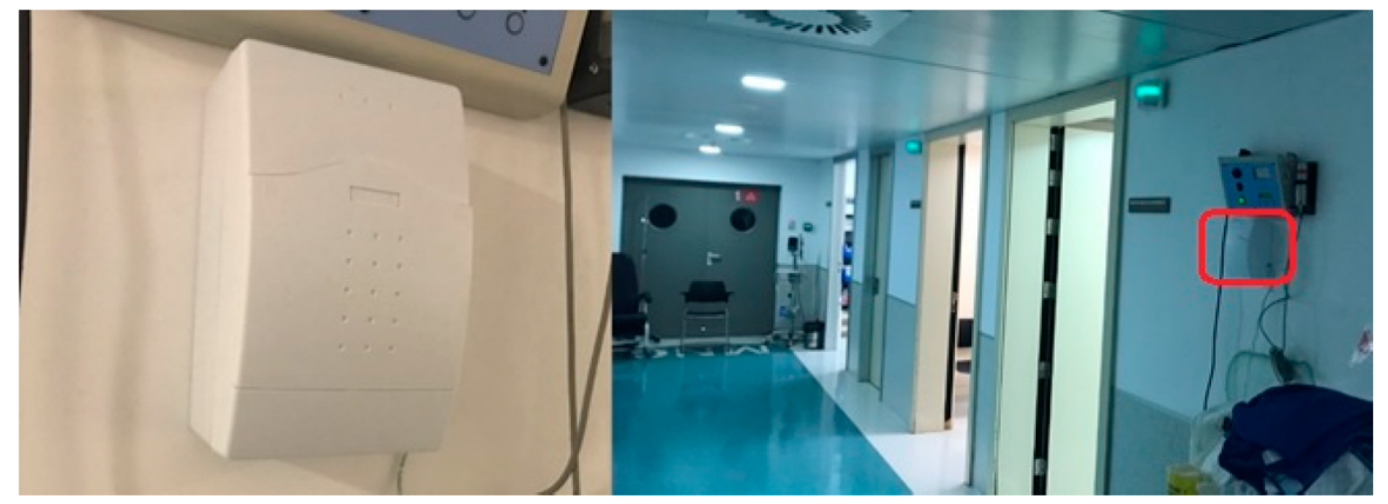

Figura 5.16: Ubicación del dispositivo como medidor de área

Se obtuvieron diferencias del $13 \%$ entre el valor medido por el dispositivo y el registrado por el dosímetro de área durante el mismo periodo de tiempo.

\section{- Como dosímetro personal:}




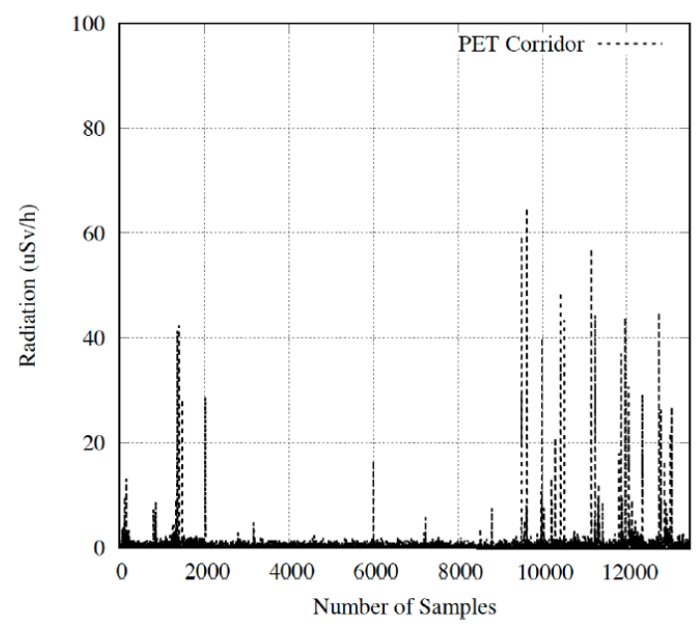

Figura 5.17: Resultados medición de dosis en el pasillo de Medicina Nuclear

se colocó en la habitación de control de la sala de TAC. Una vez recopilados todos los datos de dosis se colocaron dos dosímetros del tipo Geiger-Müller convenientemente calibrados y pertenecientes al servicio de protección radiológica del centro hospitalario durante el mismo periodo para comparar los resultados. En la Figura 5.18 se muestra la ubicación del dispositivo como medido personal para el técnico radiólogo así como los resultados de las medidas en la Figura 5.19.
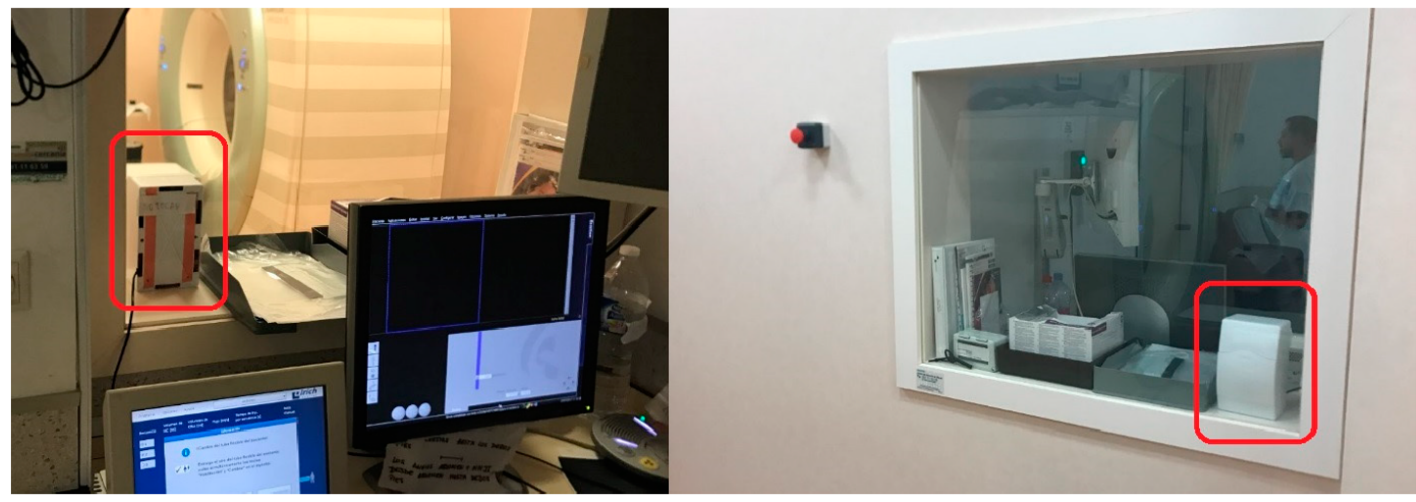

Figura 5.18: Ubicación del dispositivo en la sala de TAC

En el mismo periodo de tiempo, se apreciaron diferencias del $11 \%$ entre el valor medido por el dispositivo y el registrado por el medidor convencional de radiación. 


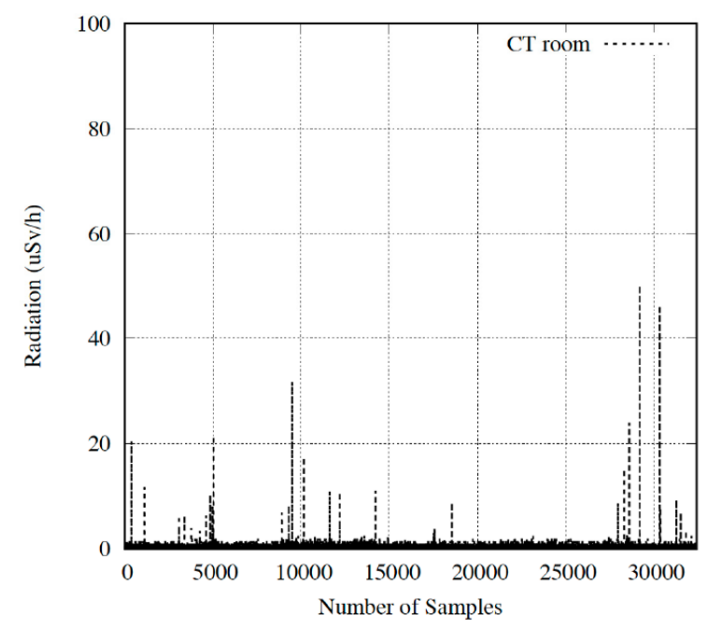

Figura 5.19: Resultados medición de dosis en la sala de TAC

\subsection{Conclusiones}

En este artículo se propone el diseño e implementación de un sistema de medición de radiación ionizante de bajo coste, de código abierto y portable para proporcionar medidas en tiempo real para un área determinada o como dosímetro personal. La solución proporcionada se basa en un tubo Geiger-Müller junto con toda la electrónica asociada con objeto de mostrar los datos y enviarlos a una base de datos remota. La visualización de datos se realiza a través de una aplicación móvil para la plataforma Android.

Para validar el sistema, en primer lugar, fue calibrado en un centro homologado para ello y, posteriormente, testeado en un entorno real como es un hospital para verificar su funcionalidad tanto como medidor de área como dosímetro personal. 


\section{Conclusiones}

Las radiaciones ionizantes en el entorno hospitalario suponen uno de los mayores riesgos que tanto los pacientes como profesionales sufren a diario cuando se realizan pruebas radiológicas en equipos que las emiten o en aquellas zonas donde hay mayor actividad de las mismas. Dado que para obtener una mejor calidad de imagen diagnóstica se debe aumentar la dosis, en los estudios radiológicos el objetivo ideal sería obtener la mejor imagen diagnosticable con la menor radiación emitida.

El control de la dosis, en términos de ajuste y optimización tanto para pacientes que son sometidos a las pruebas radiológicas como los profesionales que las realizan y trabajan en un entorno radioexpuesto ha sido uno de los objetivos que se han abordado en esta tesis.

Para la realización de este control de radiaciones a pacientes se ha puesto de manifiesto una metodología de implantación a nivel corporativo de un sistema de gestión de dosis donde se ha involucrado a todos los miembros de la organización sanitaria en conseguir un entorno seguro y controlado a radiaciones ionizantes. Dada la peculiaridad que en un sistema de salud conviven diferentes tecnologías de equipos, así como de fabricantes, se ha buscado una homogeneización de los protocolos y prácticas para que cualquier paciente, independientemente del centro sanitario al que acuda dentro del mismo servicio de salud, puedan estar seguros que reciben sus diagnósticos en un entorno controlado a radiaciones.

El proceso de optimización y disminución de dosis a paciente comienza en primer lugar 
por establecer los niveles de referencia que posea la organización y compararlas frente a otras organizaciones tanto en entornos regionales como internacionales. Para ello se han establecido los niveles de referencia en la modalidad de TAC para un área concreta de hospitales en un servicio de salud determinado dando, además, un paso más en la optimización mediante el análisis de los outliers de la distribución de esos niveles de referencia aplicando un método de detección y justificación para su mejora continua.

Para el control de radiaciones a profesionales sanitarios se ha diseñado y desarrollado un sistema de bajo coste, código abierto y conectable a cualquier sistema de gestión de dosis corporativo que habilita a la organización sanitaria de un control global de las radiaciones tanto a los pacientes como a los profesionales que la componen.

A la hora de redactar esta memoria de tesis existen dos artículos bajo revisión en sendas revistas listadas en el JCR (Journal Citation Report), contribuyendo a esta tesis en dos aspectos innovadores:

\section{- Establecimiento de niveles de referencia (DRL):}

En la actualidad, España no dispone aún de unos valores de referencia para las pruebas en la modalidad de TAC y, gracias a los datos obtenidos por un sistema de gestión de dosis en un entorno regional con diferentes fabricantes y modelos de equipos recogidos durante 4 años se pretende publicar los niveles de referencia para el $95 \%$ de las pruebas que se realizan hoy en día en cada uno de los protocolos TAC.

\section{- Predicción de valores de dosis utilizando técnicas Machine Learning:}

En este trabajo se exponen las diferentes técnicas Machine Learning que mejor ajustan el nivel de dosis con objeto de obtener una imagen diagnosticable atendiendo a tres métricas como son el IMC (Índice de Masa Corporal), CTDIvol y DRL junto con el protocolo TAC a realizar. 


\section{Bibliografía}

[1] An adjusted boxplot for skewed distributions. https://wis.kuleuven.be/stat/ robust/papers/2004/boxplotCOMPSTAT04.pdf. Último acceso: 15-07-2019.

[2] An approach to local diagnostic reference levels (drl's) in the context of national and international dr's. https://inis.iaea.org/collection/NCLCollectionStore/ _Public/32/039/32039907.pdf?r=1\&r=1, note = Último acceso: 15-07-2019.

[3] Computed tomography (ct): national patient dose audits. https://www.gov.uk/government/publications/ doses-from-computed-tomography-ct-examinations-in-the-uk. Último acceso: 15-07-2019.

[4] Directiva 2013/59/euratom. https://www. boe.es/doue/2014/013/L00001-00073. pdf. Último acceso: 15-07-2019.

[5] Dosimetría beosl. https://www.radmedical.com.mx/?page_id=2. Último acceso: 1507-2019.

[6] El sms reduce un $35 \%$ la radiación en sus pruebas de imagen médica gracias a un sistema de referencia en europa. https://www.laverdad.es/sociedad/ reduce-radiacion-reciben-20190303121246-nt.html. Último acceso: 15-07-2019.

[7] Electronic dosimeter dmc2000. https://www.dosimetry.com/images/pdf/LIT4319_ EDs_combined.pdf. Último acceso: 15-07-2019. 
[8] European nuclear society. film dosimeter. https://www.euronuclear.org/info/ encyclopedia/f/filmdosimeter.htm. Último acceso: 15-07-2019.

[9] Geiger muller counter. https://www.cpp.edu/ ${ }^{\sim} p b s i e g e l / b i o 431 /$ texnotes/ chapter4.pdf? Último acceso: 15-07-2019.

[10] Icrp publication 103. the 2007 recommendations of the international commission on radiological protection. http://www.icrp.org/publication.asp?id=ICRP\% 20Publication\%20103. Último acceso: 15-07-2019.

[11] Icrp publication 135. diagnostic reference levels in medical imaging. http://www . icrp. org/publication. asp?id=ICRP\%20Publication\%20135. Último acceso: 15-07-2019.

[12] Icrp publication 77. radiological protection policy for the disposal of radioactive waste. http://www. icrp. org/publication. asp?id=ICRP\%20Publication\%2077. Último acceso: 15-07-2019.

[13] Ionization chamber. https://www.orau.org/PTP/collection/ionchamber/ introionizationchamberr.htm. Último acceso: 15-07-2019.

[14] Llnl environmental $\mathrm{rpl}$ dosimeter. https://www.orau.org/PTP/collection/ dosimeters/ron.htm? Último acceso: 15-07-2019.

[15] Nist/sematech e-handbook of statistical methods. hhttps://www.itl.nist.gov/ div898/handbook/. Último acceso: 15-07-2019.

[16] Proportional counter. https://www.orau.org/PTP/collection/proportional\% 20 counters/introprops . htm. Último acceso: 15-07-2019.

[17] Radiation dose in x-ray and ct exams. https://www.radiologyinfo.org/en/info. cfm?pg=safety-xray. Último acceso: 15-07-2019. 


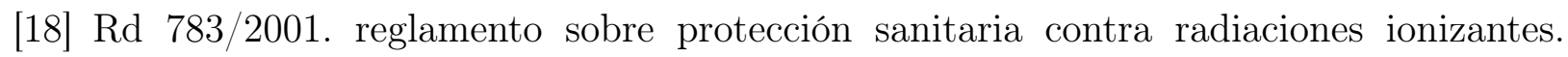
https : //www. boe.es/boe/dias/2001/07/26/pdfs/A27284-27393.pdf. Último acceso: $15-07-2019$.

[19] Scintillation detectors. http://www-physics.lbl.gov/ spieler/physics_198_ notes/PDF/III-Scint .pdf? Último acceso: 15-07-2019.

[20] Semiconductor detector. http://www-physics.lbl.gov/ spieler/SLAC_Lectures/ PDF/Sem-Det-I.pdf. Último acceso: 15-07-2019.

[21] Tld dosimeter for re-2000 readers. http://nusim.com/wp-content/uploads/2012/ 07/20996042_TLDdosimeter_EN_A.pdf. Último acceso: 15-07-2019.

[22] Gokce Kaan Atac, Aydin Parmaksiz, Tolga Inal, Emine Bulur, Figen Bulgurlu, Tolga Oncu, and Sadi Gundogdu. Patient doses from CT examinations in turkey. Diagnostic and Interventional Radiology, 21(5):428-434, August 2015.

[23] P. Charnock, B. M. Moores, and R. Wilde. Establishing local and regional DRLs by means of electronic radiographical x-ray examination records. Radiation Protection Dosimetry, 157(1):62-72, May 2013.

[24] Yingming Amy Chen, Kate MacGregor, Iris Li, Lianne Concepcion, Djeven Parameshvara Deva, Timothy Dowdell, and Bruce Garstang Gray. Tracking and resolving CT dose metric outliers using root-cause analysis. Journal of the American College of Radiology, 13(6):680-687, June 2016.

[25] Paul D. Deak, Oliver Langner, Michael Lell, and Willi A. Kalender. Effects of adaptive section collimation on patient radiation dose in multisection spiral CT. Radiology, 252(1):140-147, July 2009.

[26] J. M. Fernandez-Soto, J. I. Ten, R. M. Sanchez, M. España, X. Pifarre, and E. Vano. Benefits of an automatic patient dose registry system for interventional radiology and 
cardiology at five hospitals of the madrid area. Radiation Protection Dosimetry, 165(14):53-56, March 2015.

[27] S J Foley, M F McEntee, and L A Rainford. Establishment of CT diagnostic reference levels in ireland. The British Journal of Radiology, 85(1018):1390-1397, October 2012.

[28] E.A. Garcia-Angosto, A. Serna, A.J. Garcia-Sanchez, F. Garcia-Sanchez, and D. Ramos. A regional solution for patient radiological dose management. Physica Medica, 32:212213, September 2016.

[29] Antonio-Javier Garcia-Sanchez, Enrique Garcia Angosto, Pedro Moreno Riquelme, Alfredo Serna Berna, and David Ramos-Amores. Ionizing radiation measurement solution in a hospital environment. Sensors, 18(2):510, February 2018.

[30] K Hatziioannou, E Papanastassiou, M Delichas, and P Bousbouras. A contribution to the establishment of diagnostic reference levels in CT. The British Journal of Radiology, 76(908):541-545, August 2003.

[31] M. H. Kharita and S. Khazzam. Survey of patient dose in computed tomography in syria 2009. Radiation Protection Dosimetry, 141(2):149-161, May 2010.

[32] C J Martin, J Le Heron, C Borrás, S Sookpeng, and G Ramirez. Approaches to aspects of optimisation of protection in diagnostic radiology in six continents. Journal of Radiological Protection, 33(4):711-734, September 2013.

[33] Colin J. Martin. THE APPLICATION OF DIAGNOSTIC REFERENCE LEVELS FOR OPTIMISATION OF x-RAY IMAGING IN THE UK. Radiation Protection Dosimetry, 169(1-4):211-216, November 2015.

[34] Ruth M Nicol, Sarah C Wayte, Andrew J Bridges, and Christopher J Koller. Experiences of using a commercial dose management system (GE DoseWatch) for CT examinations. The British Journal of Radiology, 89(1057):20150617, January 2016. 
[35] D. Papadimitriou, A. Perris, A. Manetou, M. Molfetas, N. Panagiotakis, M. LyraGeorgosopoulou, K. Hourdakis, S. Kottou, G. Tosi, D. Origgi, and S. Vigorito. A survey of 14 computed tomography scanners in greece and 32 scanners in italy: Examination frequencies, dose reference values, effective dose and doses to organs. Radiation Protection Dosimetry, 104(1):47-53, April 2003.

[36] Lotte Pyfferoen, Tom H. Mulkens, Federica Zanca, Timo De Bondt, Paul M. Parizel, and Jan W. Casselman. Benchmarking adult CT-dose levels to regional and national references using a dose-tracking software: a multicentre experience. Insights into Imaging, 8(5):513-521, September 2017.

[37] J. Santos, S. Foley, G. Paulo, M. F. McEntee, and L. Rainford. The establishment of computed tomography diagnostic reference levels in portugal. Radiation Protection Dosimetry, 158(3):307-317, September 2013.

[38] A. Serna, E.A. Garcia-Angosto, A.J. Garcia-Sanchez, F. Garcia-Sanchez, and D. Ramos. Computed tomography radiation dose in a regional survey. Physica Medica, 32:287, September 2016 .

[39] Alfredo Serna, David Ramos, Enrique Garcia-Angosto, Antonio-Javier Garcia-Sanchez, Maria A. Chans, Jose M. Benedicto-Orovitg, Vicente Puchades-Puchades, and Juan F. Mata-Colodro. Optimization of CT protocols using cause-and-effect analysis of outliers. Physica Medica, 55:1-7, November 2018.

[40] P C Shrimpton, M C Hillier, M A Lewis, and M Dunn. National survey of doses from CT in the UK: 2003. The British Journal of Radiology, 79(948):968-980, December 2006.

[41] Karen E. Thomas and Bo Wang. Age-specific effective doses for pediatric MSCT examinations at a large children's hospital using DLP conversion coefficients: a simple estimation method. Pediatric Radiology, 38(6):645-656, April 2008. 
[42] E. Vañó, D.L. Miller, C.J. Martin, M.M. Rehani, K. Kang, M. Rosenstein, P. OrtizLópez, S. Mattsson, R. Padovani, and A. Rogers. ICRP publication 135: Diagnostic reference levels in medical imaging. Annals of the ICRP, 46(1):1-144, October 2017. 